\title{
Design and Synthesis of Aza-/Oxa Heterocycle-Based Conjugates as Novel Anti-Inflammatory Agents Targeting Cyclooxygenase-2
}

\author{
Sukhmeet Kaur, ${ }^{\dagger}$ Priya Kumari, ${ }^{\dagger}$ Gurjit Singh, ${ }^{\ddagger 0}$ Rajbir Bhatti, ${ }^{\ddagger}$ and Palwinder Singh* ${ }^{\dagger}{ }^{\dagger}$ \\ ${ }^{\dagger}$ Department of Chemistry—Centre for Advanced Studies and ${ }^{\ddagger}$ Department of Pharmaceutical Sciences, Guru Nanak Dev University, \\ Amritsar 143005, India
}

\section{Supporting Information}

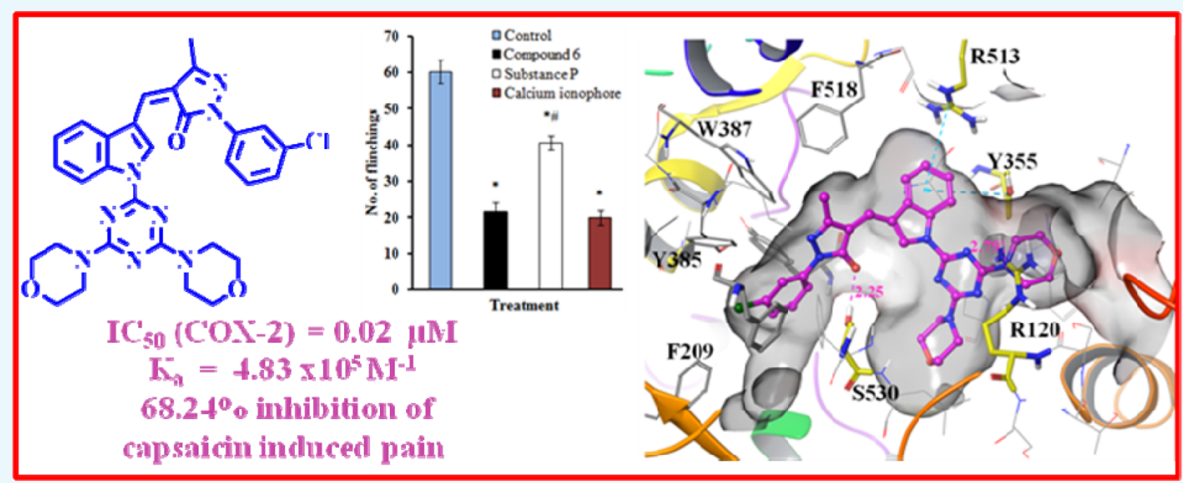

ABSTRACT: A library of hybrid molecules was procured by the combination of triazine-indole adduct with morpholine/ piperidine/pyrrolidine and pyrazole/pyrimidine/oxindole moieties. Enzyme immunoassays on cyclooxygenase-1 (COX-1) and cyclooxygenase-2 (COX-2) identified compound 6 having an $\mathrm{IC}_{50}$ value of $20 \mathrm{nM}$ for COX-2 and $3000 \mathrm{nM}$ for COX-1. The significant reduction in the formation of prostaglandin $\mathrm{E}_{2}$ in the lipopolysaccharide-treated (COX-2-activated) human whole blood, almost no change in the production of thromboxane $\mathrm{B}_{2}$ in the calcium ionophore-treated (COX-1-activated) sample of human whole blood, and the mechanistic studies on Swiss albino mice ensured that compound 6 is selective for COX-2. The association constant $\left(K_{\mathrm{a}}\right)$ of compound 6 with COX-2 was found to be of the order of $0.48 \times 10^{6} \mathrm{M}^{-1}$. The diffusion spectroscopy experiments and relaxation time $\left(T_{1}\right)$ calculations of compound 6 in the presence of COX-2 assisted in identifying the site-specific interactions of $\mathbf{6}$ with the enzyme, and these results fall into nice correlation with the theoretical data obtained from molecular docking and quantitative structure-activity relationship studies. With maximum tolerable dose $>2000 \mathrm{mg} \mathrm{kg}{ }^{-1}$, compound 6 made 68 and 32\% reduction in formalin-induced analgesia and carrageenan-induced inflammation in Swiss albino mice.

\section{INTRODUCTION}

Inflammation is a preeminent host defense to injury, infectious agents, and autoimmune responses. ${ }^{1}$ However, the chronic inflammation leads to the emergence of various diseases such as rheumatoid arthritis, neurodegenerative disorder, and cancer and cardiovascular diseases. ${ }^{2}$ The most important markers of inflammation include cytokine receptors, nitric oxide synthase (NOS), nuclear factor kappa-B, chemokines, tumor necrosis factor alpha, interferons, and proinflammatory enzymes cyclooxygenase-2 (COX-2) and lipoxygenase. ${ }^{3}$ Among these mediators, cyclooxygenases or prostaglandin endoperoxide synthases, taking part in arachidonic acid (AA) metabolism for the formation of inflammation causing prostaglandins, ${ }^{4}$ are the decisive players. Of the two isoforms of cyclooxygenases, cyclooxygenase-1 (COX-1) and COX-2 are almost identical in structure but have distinct biological functions. ${ }^{5}$ The inducible enzyme COX-2 mediates the synthesis of proinflammatory prostaglandins and thromboxanes, ${ }^{6}$ and it becomes the major therapeutic target for the treatment of inflammatory diseases.
On the other hand, housekeeping enzyme COX-1 helps in homeostasis and blood clotting. As far as the treatment of inflammatory diseases is concerned, it has mostly been dependent on the use of nonsteroidal anti-inflammatory drugs including COX-1/2 nonselective inhibitors such as aspirin, ibuprofen, indomethacin, and diclofenac and selective COX-2 inhibitors (COXIBS) such as celecoxib. ${ }^{7}$ However, the severe side effects including gastrointestinal lesions, renal injury, and cardiovascular diseases associated with the clinical usage of these therapeutic agents ${ }^{8}$ have necessitated the search for new chemical entities with higher efficacy and low/no side effects.

The pattern of exhibiting diverse biological activities by the heterocyclic moieties has imparted them paramount importance in constituting the skeleton of several medicinally

Received: March 8, 2018

Accepted: May 17, 2018

Published: May 30, 2018 
significant compounds. ${ }^{9}$ Specifically, the aza-heterocycles such as indole, pyrimidine, pyrazole, morpholine, piperidine, pyrrolidine, and triazine are serving as templates of a number of clinically used anti-inflammatory, antifungal, antileukemic, and neuroprotective agents ${ }^{10}$ and antiamoebic, anticancer, antileishmanial, antimalarial, antiviral, antitubercular, carbonic anhydrase inhibitor, cathepsin B inhibitor, and antimicrobial agents. ${ }^{11-14}$ In the context of these reports, it was envisaged that a hybrid molecule obtained by the combination of two/ three aza-heterocycles may prove more efficacious than those drugs, which are made up of the individual aza-heterocycle moieties. Therefore, in continuation to the efforts for the development of indole-pyrazole/indolinone-chrysin-based conjugates as selective COX-2 inhibitors (A-D Figure 1), ${ }^{15}$

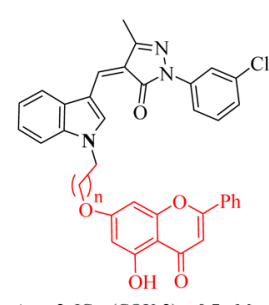

$\mathrm{A}, \mathrm{n}=2, \mathrm{IC}_{50}(\mathrm{COX}-2)=0.7 \mu \mathrm{M}$

$\mathrm{B}, \mathrm{n}=3, \mathrm{IC}_{50}(\mathrm{COX}-2)=6.2 \mu \mathrm{M}$

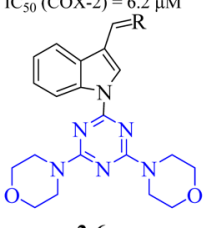

2-6

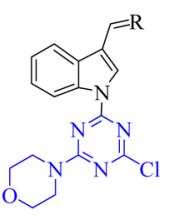

7, 18-20
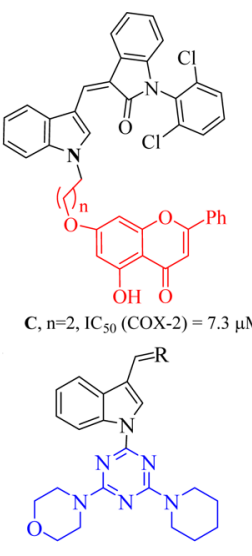

8-12

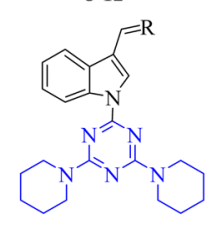

21-22

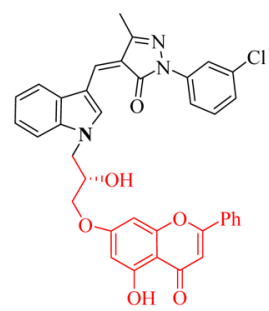

D, $\mathrm{IC}_{50}(\mathrm{COX}-2)=0.13 \mu \mathrm{M}$

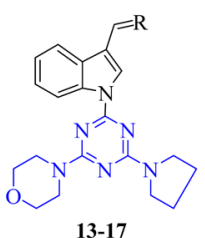

$2,7,8,13,21: R=0$

3, 9, 14, 18: $\quad R=$ indolinone

4, 10, 15, 19: $R=$ oxindole

5, 11, 16, 20: $R=1,3-$ dimethyl

barbituric acid

$6,12,17,22: \quad R=$ pyrazole
Figure 1. Previously reported molecules A-D and the library of newly designed compounds 2-22.

it was further planned to replace the chrysin moiety of the molecules with the substituted triazine. Hence, the replacement of the red colored part of molecules A-D with the blue colored component (consisting of indole, triazine, morpholine, piperidine, pyrrolidine, pyrimidine, and pyrazole heterocycles) led to the design of compounds 2-22 (Figure 1). These compounds were synthesized and screened for anti-inflammatory activity by using enzyme immunoassays and animal models. COX-2 as the cellular target of the molecules was confirmed by the in vivo mechanistic experiments supported by the physicochemical and the molecular modeling studies.

\section{RESULTS AND DISCUSSION}

2.1. Chemistry. The reaction of morpholine and cyanuric chloride provided di- and monosubstituted products $\mathbf{1 a}$ and $\mathbf{1 b}$ (Scheme 1). Taken in acetonitrile (ACN) in the presence of $\mathrm{NaH}$, compound 1a was treated with indole-3-carboxaldehyde at room temperature ( $\mathrm{rt}$ ) and compound 2 was procured. Treatment of compound 2 with 1-(2,6-dichlorophenyl)-1,3dihydroindol-2-one(indolinone)/1,3-dihydroindol-2-one(oxindole)/N,N-dimethylbarbituric acid/1-(3-chlorophenyl)-3- methyl-2-pyrazolin-5-one under microwave irradiation in the presence of piperidine afforded compounds 3-6 (Scheme 1).

Similar to the reaction of $\mathbf{1 a}$, treatment of compound $\mathbf{1 b}$ with indole-3-carboxaldehyde provided compound 7. Reaction of compound 7 with 1-(3-chlorophenyl)-3-methyl-2-pyrazolin-5one/N,N-dimethyl barbituric acid/oxindole/indolinone under microwave irradiation in the presence of piperidine afforded compounds 8-12, respectively. Likewise, compounds 13-17 were prepared when compound 7 was reacted with 1-(3chlorophenyl)-3-methyl-2-pyrazolin-5-one/ $N, N$-dimethyl barbituric acid/oxindole/indolinone in the presence of pyrrolidine under microwave irradiation (Scheme 2). Interestingly, the incorporation of a heterocycle moiety at the $\mathrm{CHO}$ group of 7 and replacement of its $\mathrm{Cl}$ with piperidine/pyrrolidine occurred in one pot. However, stepwise reaction of 7 , first with piperidine/pyrrolidine and then with the heterocycle moiety or vice versa, was also successful.

Compounds 18-20 were obtained by heating compound 7 (1 mmol) with 1-(3-chlorophenyl)-3-methyl-2-pyrazolin-5one/ $N, N$-dimethyl barbituric acid/oxindole $(1 \mathrm{mmol})$ at 155-160 ${ }^{\circ} \mathrm{C}$ for $25-30 \mathrm{~min}$ (Scheme 3).

Reaction of piperidine $(2 \mathrm{mmol})$ with cyanuric chloride (1 mmol) provided product 23 (Scheme 4). Treatment of compound 23 with indole-3-carboxaldehyde resulted into the formation of compound 21. Compound 21 on further reaction with 1-(3-chlorophenyl)-3-methyl-2-pyrazolin-5-one under microwave irradiation in the presence of piperidine provided compound 22 (Scheme 4).

Interestingly, the treatment of cyanuric chloride with indole3-carboxaldehyde provided compound 24 (Scheme 5). However, because of the high melting point $\left(>300{ }^{\circ} \mathrm{C}\right)$ and insolubility of compound $\mathbf{2 4}$ in most of the polar and nonpolar solvents, we were not able to make further derivatization of this compound.

All the compounds were characterized by using NMR, IR, and high-resolution mass spectral techniques. NMR spectral data have unambiguously assigned Z-configuration at the double bond across C9-C10 (Figure 2). On the basis of various $1 \mathrm{D}$ and $2 \mathrm{D}$ NMR experiments including ${ }^{1} \mathrm{H},{ }^{13} \mathrm{C}$, nuclear Overhauser enhancement spectroscopy (NOESY), correlation spectroscopy, heteronuclear single quantum coherence (HSQC), and heteronuclear multiple bond correlation (HMBC) (Figures 2 and 3), all the proton and carbon resonance frequencies of compound 6 were assigned. Characteristically, the peak at $\delta 8.12$ is assigned to olefinic proton (H-9). The NOESY spectrum of compound 6 clearly showed the presence of NOE between H-9 and H-15 as well as between $\mathrm{H}-9$ and $\mathrm{H}-1$ (Figures 3 and S33), which confirmed the Z-configuration at the bridged $\mathrm{C}=\mathrm{C}(\mathrm{C} 9-\mathrm{C} 10)$. Likewise, the $\mathrm{H}$ and $\mathrm{C}$ resonances of other compounds and their geometry across the bridged $\mathrm{C}=\mathrm{C}$ bond were assigned.

2.2. Biological Studies. 2.2.1. In Vitro COX inhibitory Activity. By using the protocol available with the assay kits, ${ }^{16}$ COX-1 and COX-2 inhibitory activities of compounds 2-22 were checked. The enzyme inhibition assay was based on the quantification of the prostaglandins produced by the COX in AA metabolism, in the absence and presence of the test compounds. All the compounds were tested in triplicate at $10^{-4}, 10^{-5}, 10^{-6}, 10^{-7}$, and $10^{-8} \mathrm{M}$ concentration, and the $50 \%$ inhibitory concentration $\left(\mathrm{IC}_{50}\right)$ for each of the compounds was calculated. The difference in the $\mathrm{IC}_{50}$ of the three enzyme assays was $<3 \%$, and the average of the three is reported in Table 1. 
Scheme 1. Synthesis of Compounds 2-6

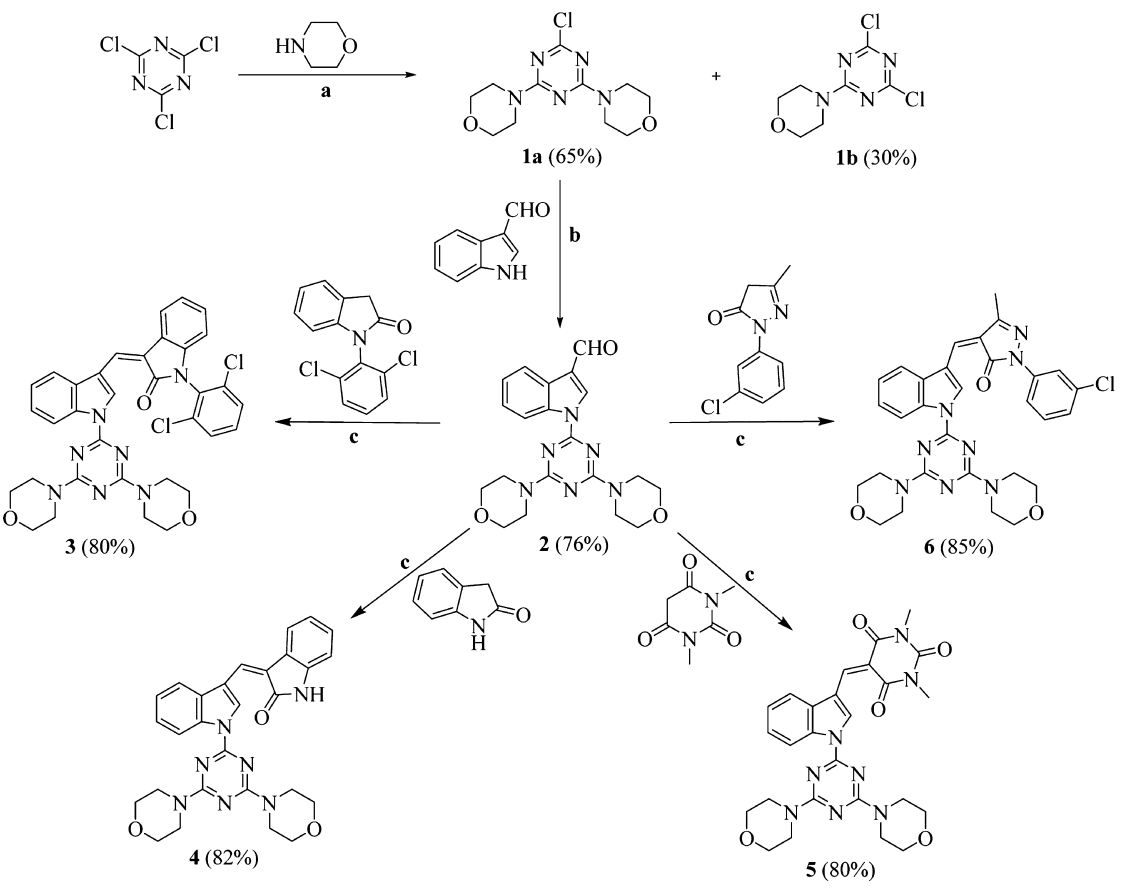

${ }^{a}$ Reagents and conditions: (a) $\mathrm{Et}_{3} \mathrm{~N}$, acetone, $4 \mathrm{~h}, 0{ }^{\circ} \mathrm{C}$ to rt; (b) $\mathrm{NaH}, \mathrm{ACN}, 3 \mathrm{~h}$, rt; and (c) $\mathrm{MWI}, \mathrm{CHCl}_{3}$, piperidine, $2 \mathrm{~h}, 100{ }^{\circ} \mathrm{C}$.

Scheme 2. Synthesis of Compounds $7-17^{a}$

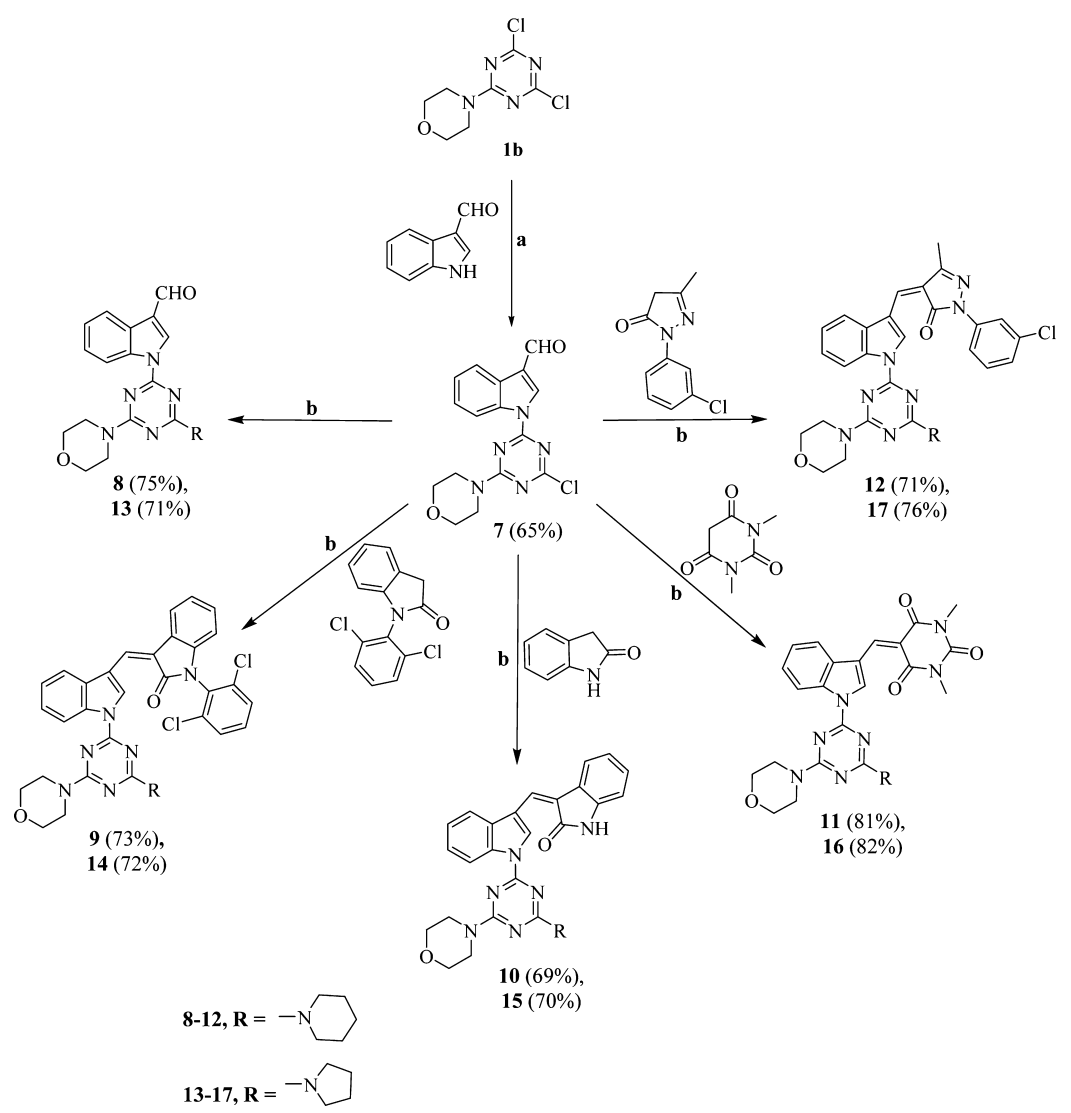

${ }^{a}$ Reagents and conditions: (a) $\mathrm{NaH}, \mathrm{ACN}, 3 \mathrm{~h}$, rt and (b) microwave irradiation (MWI), $\mathrm{CHCl}_{3}$, piperidine/pyrrolidine, $2 \mathrm{~h}, 100{ }^{\circ} \mathrm{C}$.

Appreciable inhibition of the COX-2 activity was observed in the presence of compound 2, and its $\mathrm{IC}_{50}$ was calculated 0.03 $\mu \mathrm{M}$. Desirably, it was observed that compound $\mathbf{2}$ is selective for
COX-2 over COX-1 and that the selectivity index was higher than that seen in the case of diclofenac and less than that of celecoxib. The presence of two morpholine moieties in 
Scheme 3. Synthesis of Compounds 18-20

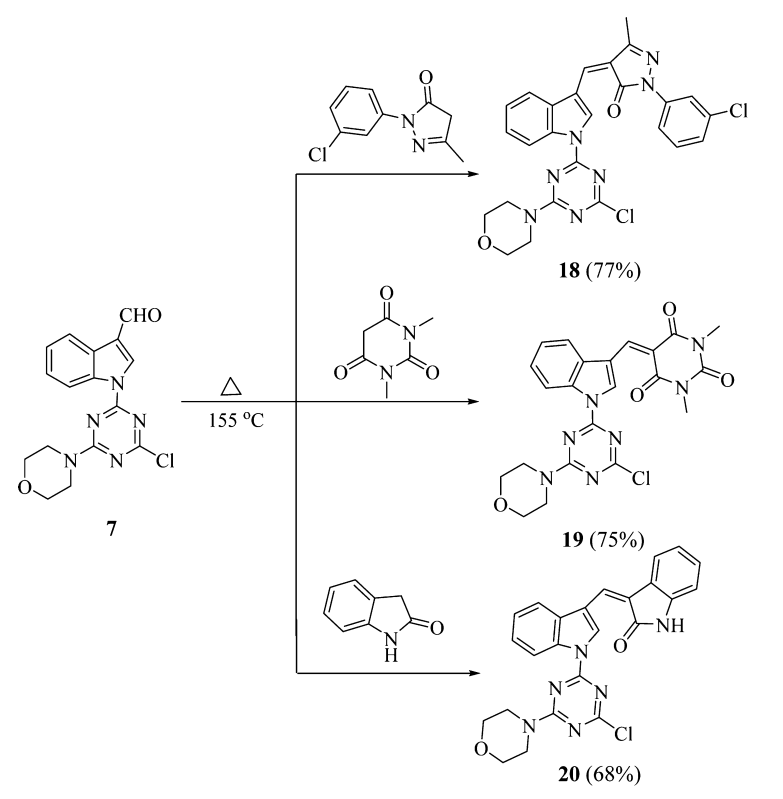

Scheme 4. Synthesis of Compounds 21-22

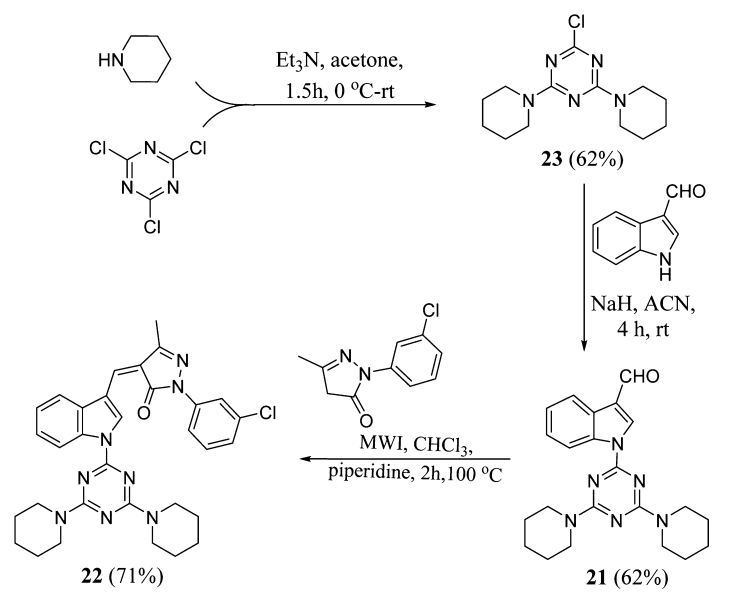

Scheme 5. Synthesis of Compound $24^{a}$

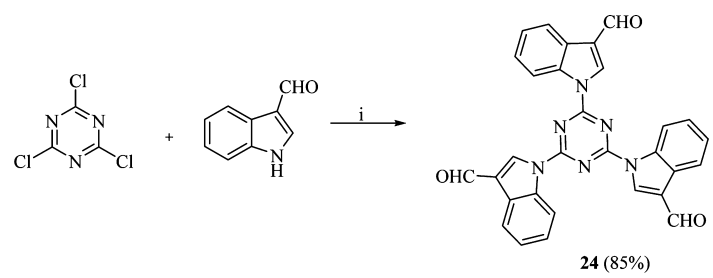

${ }^{a}$ Reagents and conditions: (i) $\mathrm{NaH}, \mathrm{ACN}, 0{ }^{\circ} \mathrm{C}, 0.5 \mathrm{~h}$.

compound 2 seems enviable for COX-2 inhibition because the analogue compounds $7,8,13$, and 21 exhibit higher $\mathrm{IC}_{50}$ than that of compound 2. Compounds 2, 7, 8, 13, and 21 were further derivatized by incorporating a heterocycle moiety at their $\mathrm{CHO}$ group.

Compounds 3-6 (obtained by the derivatization of compound 2) exhibited wide spectrum of their COX-2 inhibitory profile. Compound 6 has an $\mathrm{IC}_{50}$ of $0.02 \mu \mathrm{M}$ for COX-2, which is 2 -fold higher than that of celecoxib and is comparable to the $\mathrm{IC}_{50}$ of diclofenac. The selectivity index 150 of compound 6 for COX-2 was much better than that of

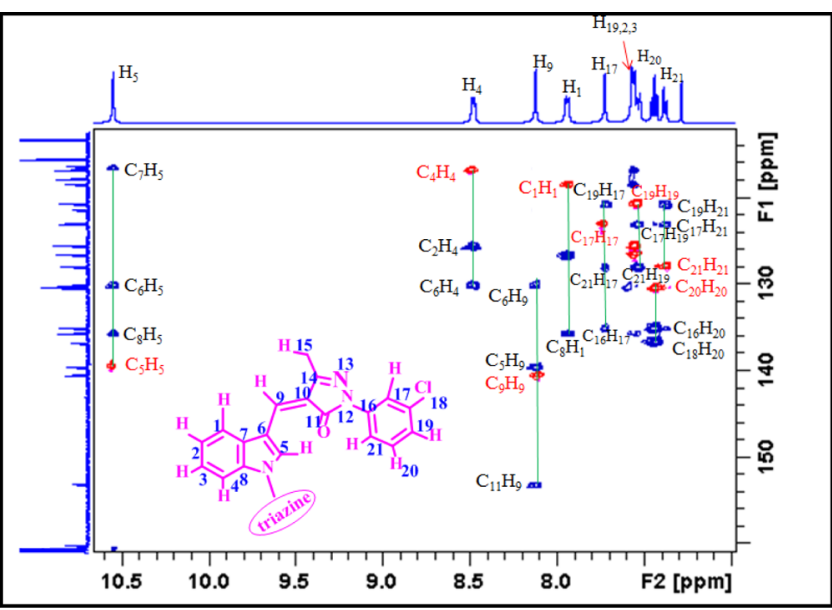

Figure 2. Overlay of HSQC (red contours) and HMBC (blue contours) NMR spectrum of compound 6.

diclofenac and indomethacin. Compound 3 with an $\mathrm{IC}_{50}$ of 0.4 $\mu \mathrm{M}$ was also found to exhibit appreciable inhibition of COX-2, whereas compound 4 exhibited an $\mathrm{IC}_{50}$ of $1 \mu \mathrm{M}$ for COX-2. The poor solubility of compound $\mathbf{5}$ in the assay medium did not allow its screening in the enzyme immunoassays.

Modification of compound 8 to compounds 9-12 also resulted into a significant variation in their $\mathrm{IC}_{50}$ for COX-2. Compounds 10, 11, and 12 exhibited $\mathrm{IC}_{50}$ values of $0.08,0.6$, and $0.05 \mu \mathrm{M}$, respectively, for COX-2. The selectivity index > 200 for compound $\mathbf{1 2}$ was appreciably higher than for diclofenac and indomethacin. However, the incorporation of a heterocycle moiety at the $\mathrm{CHO}$ group of compound 13 resulted into relatively less potent compounds 13-17. The derivatization of compound 7 into compounds 18-20 improved their COX-2 inhibitory profile. Conversion of compound $\mathbf{2 1}$ to compound 22 made 70 -fold increases in its $\mathrm{IC}_{50}$ for COX-2 (Table 1).

Apparently, the compounds 6, 18, 12, 17, and 22 obtained by the incorporation of 1-(3-chlorophenyl)-3-methyl-2-pyrazolin-5-one on compounds $2,7,8,13$, and 21, respectively, resulted into better inhibition of COX-2. Moreover, in addition to the contribution of the pyrazole moiety, the presence of two morpholine units in compound $\mathbf{6}$ also seems responsible for the higher efficacy of this compound. The role of a morpholine moiety was also apparent from the comparison of $\mathrm{IC}_{50}$ values of compound 3 with that of compounds 9 and 14. However, for compounds $4,10,15$, and 20, compound 10 with morpholine and piperidine moieties along with oxindole exhibited better $\mathrm{IC}_{50}(0.08 \mu \mathrm{M})$ for COX-2. In this group, compound 4 with two morpholine units along with oxindole has an $\mathrm{IC}_{50}$ value of $1 \mu \mathrm{M}$. Conspicuously, the presence of a pyrrolidine moiety in compounds 14, 15, and 17 increased the $\mathrm{IC}_{50}$ in comparison to that of compounds $3,9,4,10,6$, and 12 . Therefore, the analysis of the data given in Table 1 indicated that the morpholine/ piperidine/pyrrolidine moiety contributes for the COX-2 inhibition in association with the heterocycle unit present on C-3 of indole. Hence, the prevalence of significant structureactivity relationship in these compounds may not put them into the category of PAINS assay. ${ }^{17}$ Overall, the presence of two morpholine units and a pyrazole-bearing indole moiety on the triazine template was optimized for the COX-2 inhibitory activity. On the basis of the preliminary investigations, compounds $2,3,4,6,10,12,17,18$, and 22 were further 


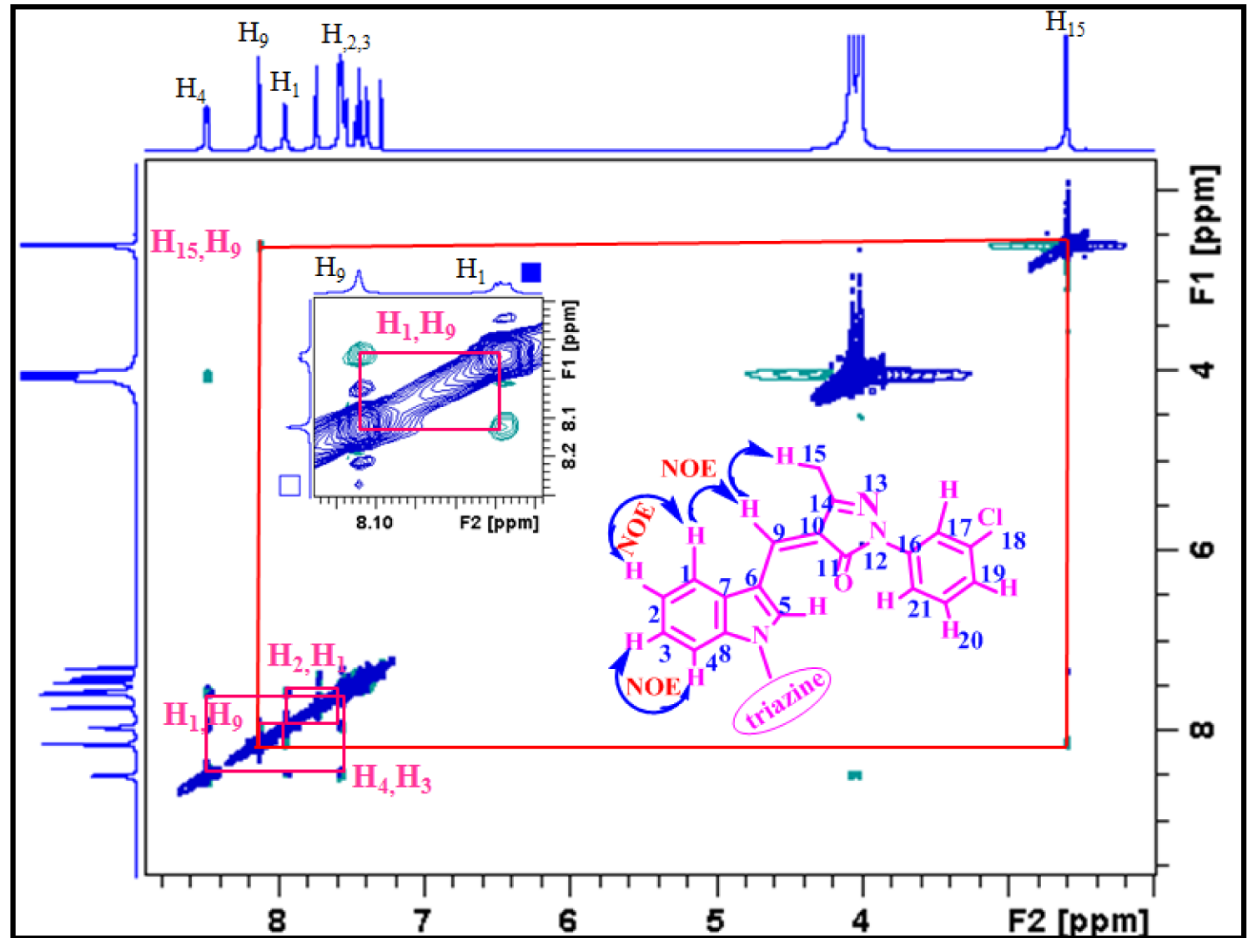

Figure 3. ${ }^{1} \mathrm{H}-{ }^{1} \mathrm{H}$ NOESY NMR spectrum of compound 6. Inset: expansion of a part of the spectrum.

screened over the animal models for their analgesic and antiinflammatory activity.

2.2.2. Human Whole Blood COX-1 and COX-2 Assay. Calcium ionophore (A23187)-stimulated production of thromboxane $\mathrm{B}_{2}\left(\mathrm{TXB}_{2}\right)$ in whole blood platelets was used to measure the activity of COX-1, whereas prostaglandin $\mathrm{E}_{2}$ $\left(\mathrm{PGE}_{2}\right)$ production in lipopolysaccharide (LPS)-stimulated whole blood was used to assess the COX-2 activity. ${ }^{18}$ In both the cases, enzyme-linked immunosorbent assays were performed. ${ }^{16,19}$ These assays measured the amount of $\mathrm{TXB}_{2}$ and $\mathrm{PGE}_{2}$ in the serum that was produced in the presence and absence of the compound.

$$
\text { Absorbance }=1 /\left[\mathrm{TXB}_{2}\right] \text { or }\left[\mathrm{PGE}_{2}\right]
$$

A23187-stimulation of human whole blood resulted in the increase in $\mathrm{TXB}_{2}$ production compared with the control blood sample (Table 2). Addition of $1 \mu \mathrm{M}$ of compounds 6, 10, 12, and $\mathbf{1 7}$ to the blood sample did not affect ionophore-stimulated $\mathrm{TXB}_{2}$ production, indicating that compounds $6,10,12$, and 17 exhibited almost negligible inhibition of COX-1. On the other hand, LPS stimulation of human whole blood increased the $\mathrm{PGE}_{2}$ production compared with the control blood sample (Table 2, Figure 4), and the addition of $1 \mu \mathrm{M}$ of compounds 6, 10, 12, and 17 significantly decreased the $\mathrm{PGE}_{2}$ production, hence indicating that compounds $6,10,12$, and 17 inhibited COX-2.

2.2.3. In Vivo Biological Studies. In vivo biological experiments were performed with the Swiss albino mice of either sex weighing 25-30 g. The study design was duly approved by the Institutional Animal Ethical Committee (IAEC). The formalin-induced hyperalgesia and carrageenaninduced paw inflammation models were used to study the analgesic and anti-inflammatory activities, respectively, of the compounds $2,3,4,6,10,12,17,18$, and $22 .{ }^{20}$ For analgesic activity, 11 groups of animals comprising five animals in each group were used. Group 1 was administered vehicle, group 2 diclofenac $\left(10 \mathrm{mg} \mathrm{kg}^{-1}\right)$, and groups 3-11 received compounds $2,3,4,6,10,12,17,18$, and 22 , respectively, at the dose of 10 $\mathrm{mg} \mathrm{kg} \mathrm{k}^{-1}$. All the compounds were administered intraperitoneally (i.p.) $30 \mathrm{~min}$ before formalin injection. For studying if COX, LOX, and nitric oxide pathways are the potential targets of the compounds, three groups including five animals per group were used. These groups received substance $\mathrm{P}$ (COX and LOX pathway stimulator), L-arginine (NO donor), and L-NAME (NOS inhibitor) $30 \mathrm{~min}$ before the most potent compound $\mathbf{6}$ was given and then were injected formalin after $30 \mathrm{~min}$. To check if voltage-gated sodium channels and calcium influx processes are targeted by the compounds, the animals were pretreated with veratrine and A23187, respectively. For anti-inflammatory activity, three groups were used. The first group served as control, the second group was treated with standard drug indomethacin $\left(10 \mathrm{mg} \mathrm{kg}^{-1}\right)$, and the third received the most potent compound $\mathbf{6}$, followed by carrageenan.

2.2.3.1. Formalin-Induced Analgesia. Administration of diclofenac and compounds 2, 3, 4, 6, 10, 12, 17, 18, and 22 significantly decreased the number of flinching in the inflammatory phase as compared to the control group (Figure 5, Table 3). The effect of compounds 6, 12, and 17 was relatively higher in the series, although the difference in the analgesic effect of the various other analogues was statistically nonsignificant. Compounds 6, 12, and 17 were found to decrease formalin-induced analgesia by $68.24,74.25$, and $69 \%$, respectively. The analgesic effect of compound 6 was significantly attenuated on pretreatment with substance $P$, whereas pretreatment with nitric oxide donor, L-arginine, or NOS inhibitor L-NAME did not alter the analgesic effect of compound 6 (Figure 6). Because substance $\mathrm{P}$ is known to stimulate COX-2 and LOX pathways ${ }^{15 b}$ and compound 6 did not inhibit 5-LOX activity (as determined by the enzyme 
Table 1. $\mathrm{IC}_{50}(\mu \mathrm{M})$ of Compounds $2-22$ against COX-1 and COX-2

\begin{tabular}{|c|c|c|c|c|c|c|}
\hline \multicolumn{4}{|c|}{ Compound } & \multicolumn{2}{|c|}{$\mathrm{IC}_{50}(\boldsymbol{\mu} \mathrm{M})$} & \multirow{2}{*}{$\begin{array}{l}\text { Selectivity } \\
\text { Index* }\end{array}$} \\
\hline No. & $\mathbf{X}$ & $\mathbf{R}_{1}$ & $\mathbf{R}_{2}$ & $\operatorname{cox}-1$ & COX-2 & \\
\hline 2 & $\mathrm{O}$ & & oxygen & 0.8 & 0.03 & 26.6 \\
\hline 3 & $\mathrm{O}$ & & $\begin{array}{l}\text { 1-(2,6-dichlorophenyl)-1,3- } \\
\text { dihydroindol-2-one } \\
\text { (indolinone) }\end{array}$ & 10 & 0.4 & 25 \\
\hline 4 & $\mathrm{O}$ & & $\begin{array}{l}\text { 1,3-dihydroindol-2-one } \\
\text { (oxindole) }\end{array}$ & $>100$ & 1 & $>100$ \\
\hline 5 & $\mathrm{O}$ & & N,N-dimethyl barbituric acid & nd & nd & nd \\
\hline 6 & $\mathrm{O}$ & & $\begin{array}{l}\text { 1-(3-chlorophenyl)-3- } \\
\text { methyl-2-pyrazolin-5-one }\end{array}$ & 3 & 0.02 & 150 \\
\hline 7 & $\mathrm{O}$ & $\mathrm{Cl}$ & oxygen & $>10$ & 10 & $>1$ \\
\hline 8 & $\mathrm{O}$ & & oxygen & 1 & 0.7 & 1.42 \\
\hline 9 & $\mathrm{O}$ & & indolinone & $>10$ & 1 & $>10$ \\
\hline 10 & $\mathrm{O}$ & & oxindole & $>10$ & 0.08 & $>125$ \\
\hline 11 & $\mathrm{O}$ & & $\mathrm{N}, \mathrm{N}$-dimethyl barbituric acid & $>10$ & 0.6 & $>16.6$ \\
\hline 12 & $\mathrm{O}$ & & $\begin{array}{l}\text { 1-(3-chlorophenyl)-3- } \\
\text { methyl-2-pyrazolin-5-one }\end{array}$ & $>10$ & 0.05 & $>200$ \\
\hline 13 & $\mathrm{O}$ & & oxygen & 5 & 2 & 2.5 \\
\hline 14 & $\mathrm{O}$ & & indolinone & 5 & 4 & 1.25 \\
\hline 15 & $\mathrm{O}$ & & oxindole & $>10$ & 8 & $>1.25$ \\
\hline 16 & $\mathrm{O}$ & & $\mathrm{N}, \mathrm{N}$-dimethyl barbituric acid & $>10$ & 6 & $>1.66$ \\
\hline 17 & $\mathrm{O}$ & & $\begin{array}{l}\text { 1-(3-chlorophenyl)-3- } \\
\text { methyl-2-pyrazolin-5-one }\end{array}$ & 7 & 1 & 7 \\
\hline 18 & $\mathrm{O}$ & $\mathrm{Cl}$ & $\begin{array}{l}\text { 1-(3-chlorophenyl)-3- } \\
\text { methyl-2-pyrazolin-5-one }\end{array}$ & $>10$ & 0.1 & $>100$ \\
\hline 19 & $\mathrm{O}$ & $\mathrm{Cl}$ & $\mathrm{N}, \mathrm{N}$-dimethyl barbituric acid & 0.6 & 0.1 & 6 \\
\hline 20 & $\mathrm{O}$ & $\mathrm{Cl}$ & oxindole & $>10$ & 2 & $>5$ \\
\hline 21 & $\mathrm{CH}_{2}$ & & oxygen & $>10$ & 7 & $>1.42$ \\
\hline 22 & $\mathrm{CH}_{2}$ & $\sqrt{n}>$ & $\begin{array}{l}\text { 1-(3-chlorophenyl)-3- } \\
\text { methyl-2-pyrazolin-5-one }\end{array}$ & 6 & 0.1 & 60 \\
\hline Diclofenac & & & & 0.07 & 0.02 & 3.5 \\
\hline Celecoxib & & & & 15 & 0.04 & 375 \\
\hline Indomethacin & & & & 0.08 & 0.96 & 0.08 \\
\hline
\end{tabular}

${ }^{a} \mathrm{IC}_{50}(\mathrm{COX}-1) / \mathrm{IC}_{50}(\mathrm{COX}-2)$.

immunoassay, $\mathrm{IC}_{50}>100 \mu \mathrm{M}$ ), the analgesic effect of this compound was probably due to the inhibition of the COX-2 pathway. Because the analgesic effect of compound 6 was not altered on L-arginine or L-NAME pretreatment, the nitric oxide pathway may not be involved in the observed effect (Figure 6). Moreover, TXA2 stimulator A23187 pretreatment did not alter the analgesic effect of compound $\mathbf{6}$, which indicated that compound 6 does not affect COX-1.

2.2.3.2. Anti-Inflammatory Studies. A marked increase in the paw thickness of the control animals was observed on carrageenan injection, and it was reached maximum by $30-45$ min of injection. Treatment of the animals with indomethacin and compounds 6 and $\mathbf{1 2}$ was found to decrease the paw thickness significantly as compared to the untreated control group (Figure 7 ). In our experiments, decrease of $18 \%$ (30 $\mathrm{min})$ and $14 \%(60 \mathrm{~min})$ in paw thickness at peak response time $(30-60 \mathrm{~min})$ was noticed in the presence of compound 6, whereas the presence of indomethacin decreased inflammation by $30 \%(30 \mathrm{~min})$ and $25 \%(60 \mathrm{~min})$ (Figure 7$)$.

2.2.3.3. Acute Toxicity Studies. OECD guidelines for the acute oral toxicity of 14 days duration were followed for checking the toxicity of compound $\mathbf{6 .}^{21}$ Briefly, four groups comprising three animals in each group were studied. Vehicle was given to the first group, whereas second, third, and fourth groups were treated with compound 6 at 50,300, and $2000 \mathrm{mg}$ $\mathrm{kg}^{-1}$ dose. As per the protocol of acute toxicity studies, there 
Table 2. Results of Enzyme Immunoassays Showing the Role of Compounds 6, 10, 12, and 17 (Final Concn $1 \mu \mathrm{M}$ ) in Inhibition of Calcium Ionophore-Stimulated $\mathrm{TXB}_{2}$ and LPSStimulated $\mathrm{PGE}_{2}$ in Whole Blood

\begin{tabular}{|c|c|c|c|c|}
\hline & \multicolumn{2}{|c|}{$\mathrm{TXB}_{2}(\mathrm{ng} / \mathrm{mL})$} & \multicolumn{2}{|c|}{$\mathrm{PGE}_{2}(\mathrm{ng} / \mathrm{mL})$} \\
\hline & $\begin{array}{c}\text {-calcium } \\
\text { ionophore }\end{array}$ & $\begin{array}{l}\text { +calcium } \\
\text { ionophore }\end{array}$ & -LPS & +LPS \\
\hline control & 0.16 & 2.00 & 0.145 & 1.98 \\
\hline indomethacin & & 1.05 & & 1.35 \\
\hline 6 & & 1.85 & & 0.91 \\
\hline 10 & & 1.55 & & 1.02 \\
\hline 12 & & 1.75 & & 0.95 \\
\hline 17 & & 1.70 & & 1.00 \\
\hline
\end{tabular}

was no mortality or any gross behavioral impairment after the 14th day. The tissue histology revealed no significant lesions except for some degree of congestion especially in the renal photomicrograph, and also the mesangium appeared shrunken and increased capsular space was seen in comparison to the control group (Figure 8). Hence, desirably, compound 6 did not exhibit toxicity even at a dose of $2000 \mathrm{mg} \mathrm{kg}^{-1}$.

2.3. In Vivo Pharmacokinetic Studies. The in vivo pharmacokinetic studies of compound 6 were carried out by using a male wistar rat $(250-300 \mathrm{~g})$. The compound was suspended in $0.1 \%$ critical micelle concentration (CMC) and administered i.p. to the rats at a dose of $10 \mathrm{mg} \mathrm{kg}^{-1}$. The animals were anesthetized with ketamine $\left(50 \mathrm{mg} \mathrm{kg}^{-1}\right.$ i.p.). The blood samples were withdrawn from the jugular vein at an interval of 30 and $60 \mathrm{~min}$ and 2, 3, 4, 6, 8, 11, and $24 \mathrm{~h}$ of compound administration. The concentration of compound in the serum was determined using liquid chromatography-mass spectrometry (LC-MS). The different pharmacokinetic parameters were determined (Table 4, Figure 9) following non compartmental analysis in $\mathrm{PK}$ solver software. Compound 6 exhibited half-life $5.5 \mathrm{~h}$ and $C_{\max } 58.5 \mu \mathrm{g} \mathrm{mL}{ }^{-1}$.

2.4. Isothermal Titration Calorimetric (ITC) and UVVis Experiments. Because the biological results were in favor of COX-2 as the cellular target of compound 6 , the binding affinity of the compound with the enzyme was checked with ITC experiments. Isothermal titration calorimetry measures the magnitude of the two thermodynamic terms: the enthalpy $(\Delta H)$ and entropy $(\Delta S)$ change in a single experiment and the combination of these two parameters defines the binding affinity (binding constant, $K$ ) between the two chemical entities. The solution of enzyme in phosphate buffer at $\mathrm{pH} 7.4$ was put in the sample cell, and the solution of compound 6 (in the syringe) was injected stepwise $(2 \mu \mathrm{L}$ of $50 \mu \mathrm{M})$ after an

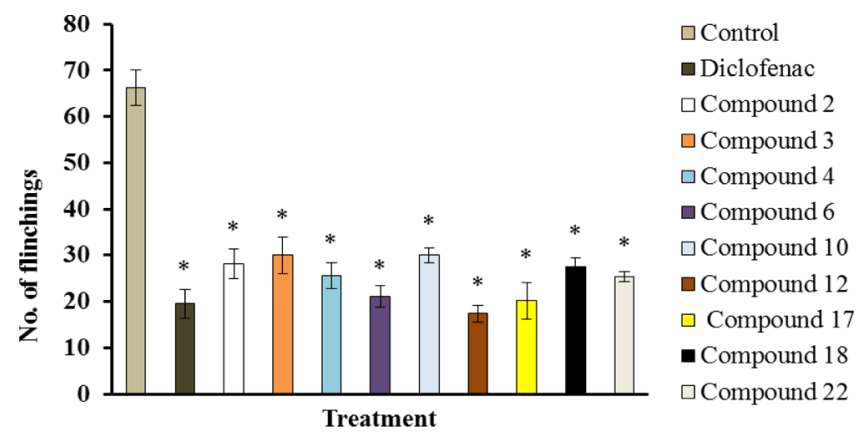

Figure 5. Graph showing change in formalin-induced hyperalgesia in the presence of compounds $2,3,4,6,10,12,17,18$, and 22. The values are given as mean $\pm \mathrm{SD}, *$ is $p<0.05$ vs control.

Table 3. Analgesic Activity of Compounds 2, 3, 4, 6, 10, 12 , 17,18 , and 22

\begin{tabular}{cc} 
compd & \% inhibition of algesia (analgesic effect) \\
$\mathbf{2}$ & 57.41 \\
$\mathbf{3}$ & 55.56 \\
$\mathbf{4}$ & 61.34 \\
$\mathbf{6}$ & 68.24 \\
$\mathbf{1 0}$ & 54.85 \\
$\mathbf{1 2}$ & 74.25 \\
$\mathbf{1 7}$ & 69.02 \\
$\mathbf{1 8}$ & 58.95 \\
$\mathbf{2 2}$ & 61.94 \\
\hline
\end{tabular}

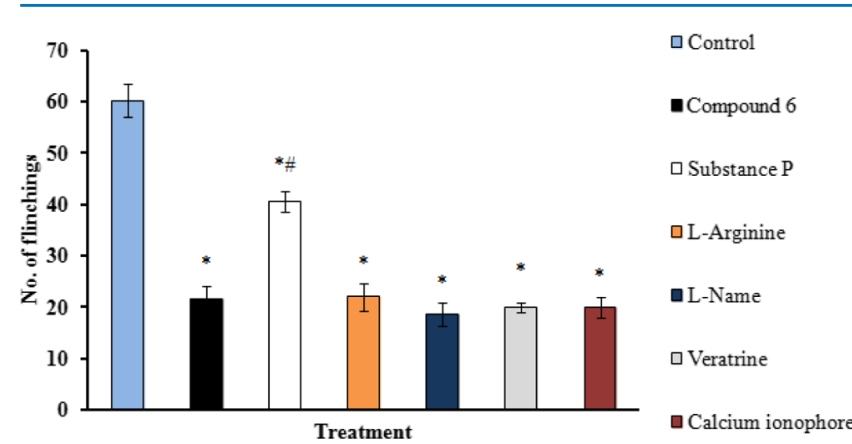

Figure 6. Study of the mechanism of analgesic effect of compound 6 by using substance $\mathrm{P}$, L-arginine, L-NAME, veratrine, and calcium ionophore. All values are given as mean $\pm \mathrm{SD}$, \# is $p<0.05$ vs compound 6.

interval of $120 \mathrm{~s}$. For one experiment, 19 consecutive additions of the compound were made, and $K_{a}, \Delta \mathrm{H}$, and $\Delta S$ were measured. The heat change $Q$ involved in the active cell during
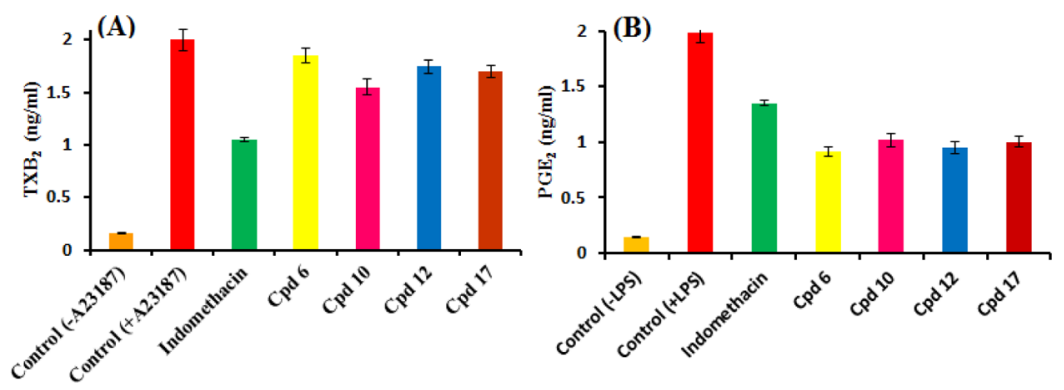

Figure 4. Graphical representation of the data given in Table 2. (A) $\mathrm{TXB}_{2}$ production in the presence of compounds is the same as in the control experiment, indicating that compounds did not inhibit COX-1. (B) $\mathrm{PGE}_{2}$ production in the presence of compounds is significantly lower than the control experiment indicating the inhibition of COX-2. 


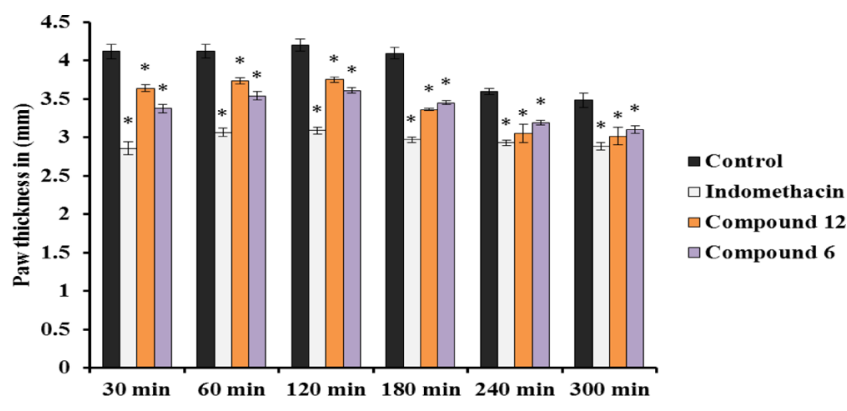

Figure 7. Effect of compounds $\mathbf{6}$ and $\mathbf{1 2}$ on carrageenan-induced paw inflammation in mice. The values are taken as mean \pm SEM. ${ }^{*} p<0.05$ vs control group.

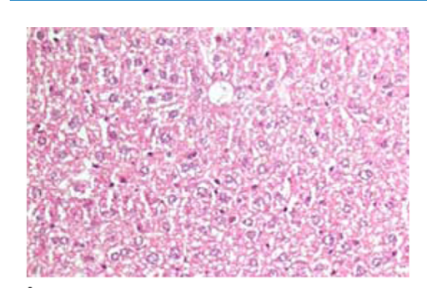

A

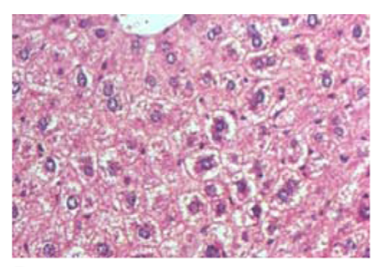

B

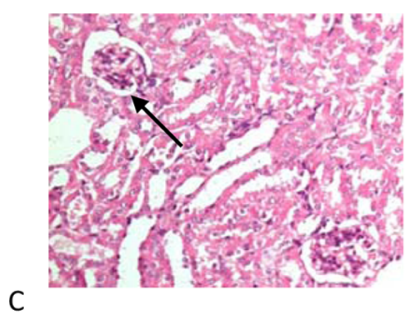

C

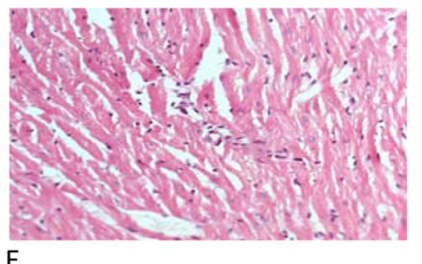

$\mathrm{E}$

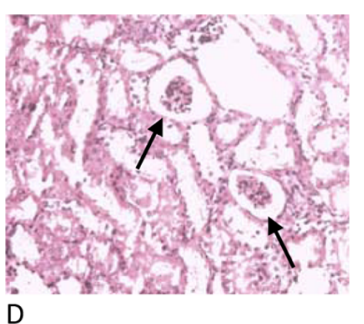

D

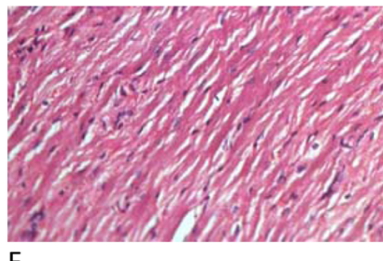

$\mathrm{F}$

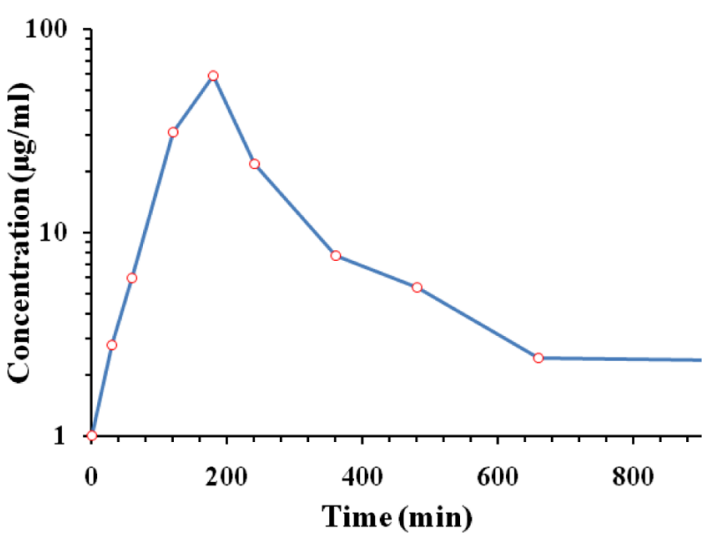

Figure 9. Pharmacokinetic study of compound 6.

For the $i$ th injection of the compound with volume $\mathrm{d} V_{i}$ to the cell-containing enzyme, the enthalpy change $\Delta H(i)$ is given by eq 2 and the values of different parameters are given in Table 5.

$$
\begin{aligned}
\Delta H(i)= & Q(i)+\mathrm{d} V_{i} / V_{\mathrm{o}}[Q(i)-Q(i-1) / 2] \\
& -Q(i-1)
\end{aligned}
$$

The negative values of free energy $(\Delta G=-33.41 \mathrm{~kJ} / \mathrm{mol})$ and enthalpy $(\Delta H=-40.52 \mathrm{~kJ} / \mathrm{mol})$ indicated that the binding of compound 6 with COX-2 is spontaneous and exothermic.

UV-vis spectral studies with the solution of compound 6 and COX-2 were also performed, and the binding constant of the compound with COX-2 was calculated using the BenesiHildebrand equation.

$$
\left.1 /\left(A_{\mathrm{f}}-A_{\mathrm{obs}}\right)=1 /\left(A_{\mathrm{f}}-A_{\mathrm{fc}}\right)+1 / K\left(A_{\mathrm{f}}-A_{\mathrm{fc}}\right) \text { [ligand }\right]
$$

where $A_{\mathrm{f}}$ is the absorbance of the free host, $A_{\mathrm{obs}}$ is the absorbance observed, $A_{\mathrm{fc}}$ is the absorbance at saturation, $K$ is the binding constant, and $L$ is the ligand concentration. Compound 6 showed significant interaction with COX-2 with a binding constant, $K_{\mathrm{a}} 1.92 \times 10^{5} \mathrm{M}^{-1}$.

2.5. Docking Studies and Molecular Dynamics (MD) Simulation. Molecular docking of the compounds in the enzyme active site was performed so that the nature of interactions between the compounds and the active site amino acid residues of the enzyme is explored. A $2.4 \AA$ resolution structure of ovine COX-2 in complex with AA (PDB ID $1 \mathrm{CVU})^{22}$ and a $3.0 \AA$ A resolution structure of COX-1 in complex with AA (PDB ID 1DIY $)^{23}$ were taken from the protein data bank (www.rcsb.org). After refinement, these proteins were used for performing molecular docking and MD experiments. Flexibly docking mode of Schrodinger software package ${ }^{24}$ was used for molecular docking, and the nature of interactions of compounds with the surrounding amino acids was parameterized by using the binding modes and binding affinities in the active site of COX-2. Docking procedure was validated by docking AA in the active site of COX-2, and its root-meansquare deviation (rmsd) from the native AA was $1.18 \AA$ (Figure S152). Compound 6 exhibited two H-bond interactions through its carbonyl oxygen and one of the three nitrogens of triazine with $\operatorname{S530}(2.25 \AA)$ and R120 (2.79 A) 一the amino acids which play major role during the catalytic phase of COX-2 (Figure 10a). It also displayed $\pi-\pi$ interactions with Y355 and cation $-\pi$ interaction with R513 (Figure 10a,b). Compounds 3, $4,8,10,11,12,13,17,18,19$, and 22 also showed well-docked poses in the COX-2 active site (Figures S153-S198, Supporting Information) exhibiting $\mathrm{H}$-bond and hydrophobic 
Table 5. Isothermal Calorimetric Data of Compound 6 during Its Interaction with COX-1 and COX-2

\begin{tabular}{ccc}
\hline Physical parameters & COX-1 & COX-2 \\
\hline $\mathrm{K}_{\mathrm{a}}\left(\mathrm{M}^{-1}\right)$ & $(3.25 \pm 0.285) \times 10^{4}$ & $(4.83 \pm 0.432) \times 10^{5}$ \\
$\Delta \mathrm{H}(\mathrm{kJ} / \mathrm{mol})$ & $-32.29 \pm 1.5$ & $-40.52 \pm 1.3$ \\
$\mathrm{~T} \Delta \mathrm{S}(\mathrm{kJ} / \mathrm{mol})$ & -5.459 & -7.107 \\
$\Delta \mathrm{G}(\mathrm{kJ} / \mathrm{mol})$ & -26.84 & -33.413
\end{tabular}

Binding Isotherm for COX-1

(a)

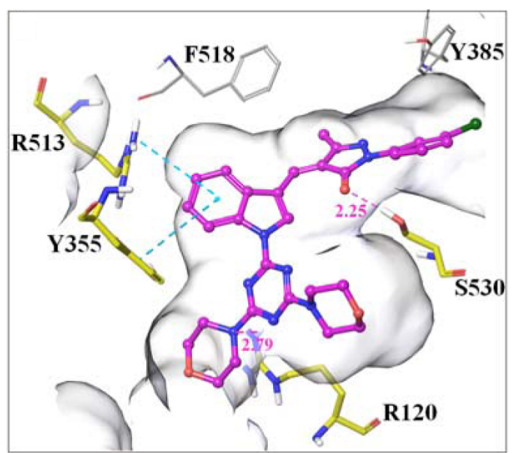

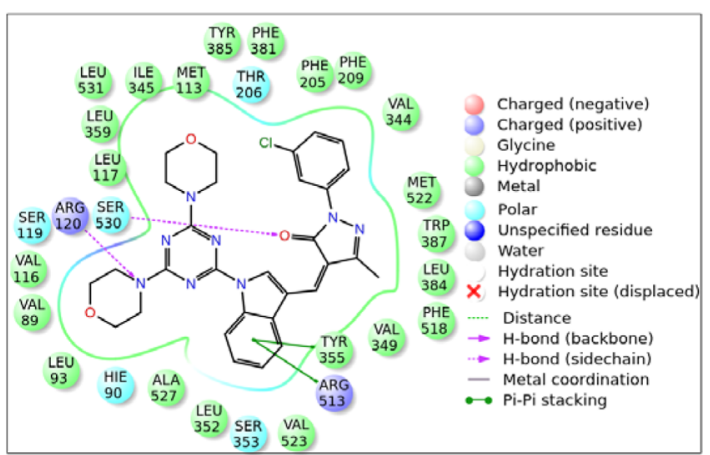

(b)

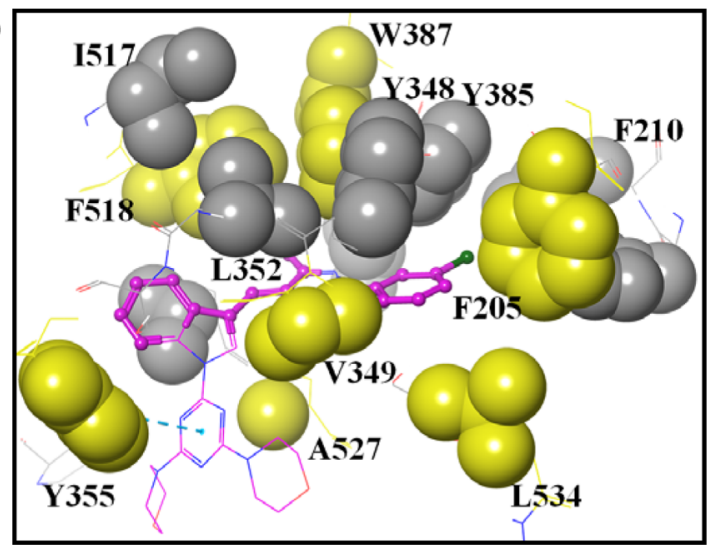

Figure 10. (a) Crystal coordinates of compound 6 in association with the COX-2 active site (PDB ID 1CVU): (A) 3D view and (B) 2D view. (b) Hydrophobic interactions of compound 6 with the active site residues of COX-2.

interactions. However, compounds $\mathbf{9}$ and $\mathbf{1 4}$ did not dock in the active site pocket of COX-2.

To elucidate the importance of protein flexibility in the ligand binding site and to observe the dynamics of proteinligand interactions, the energy-minimized docked complex of compound 6 with COX-2 was subjected to MD simulations in an aqueous solution environment for $50 \mathrm{~ns}$. The overall stability of the system under simulation was evaluated using the rmsd of the backbone atoms. It was found that the rmsd of the protein backbone is significantly stable over the course of the MD simulation (Figure 11). The oxygen atom of morpholine and the nitrogen atom of the triazine ring of compound $\mathbf{6}$ effectively interact with the surrounding water molecules, which in turn are involved in the formation of hydrogen bonds with E524 and R513 (Figure 12). The stacked bar charts were normalized over the course of the trajectory. V523 formed strong hydrophobic interactions with compound 6 , which were conserved along the simulations. Compound $\mathbf{6}$ formed hydrogen bonds and hydrophobic interactions with Y355 and L352 for more than $50 \%$ of the simulation time (Figure 13). N87 also contributed in $\mathrm{H}$-bonding and water bridges with the ligand. Moreover, H90, P86, Y385, F518, and A527 exhibited polar and nonpolar interactions for $<50 \%$ of the $\mathrm{MD}$ time.

Compound 10 also showed well-docked pose in the COX-2 active site. $\mathrm{H}$-bonding interactions through one of the nitrogens of triazine with phenolic - $\mathrm{OH}$ of $\mathrm{Y} 355$ side chain $(2.23 \AA)$ and 


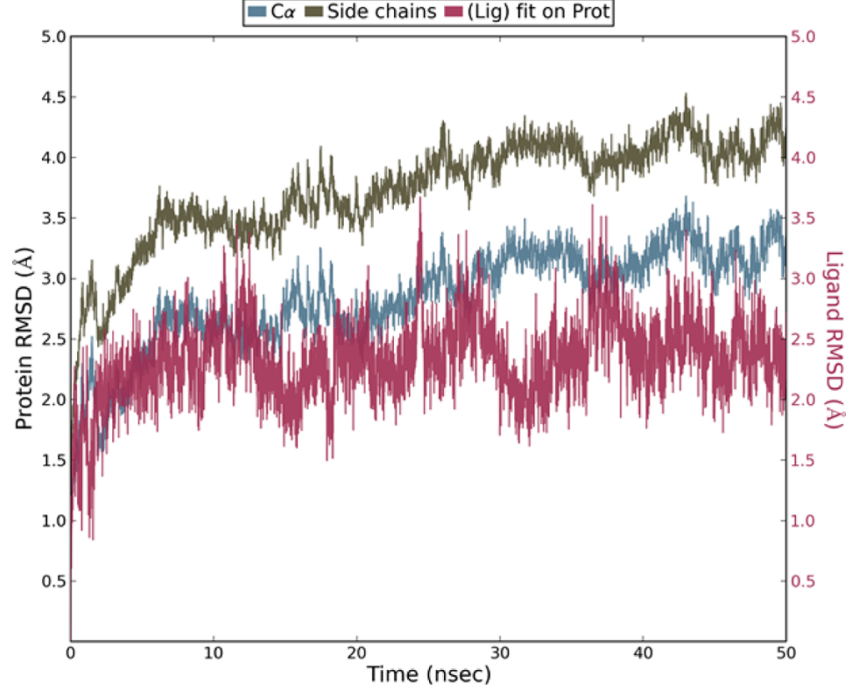

Figure 11. Rmsd of backbone atoms during evolution of trajectory of $\mathrm{C} \alpha$ (blue), side chain of protein (brown), and atoms of ligand 6 (pink) are shown

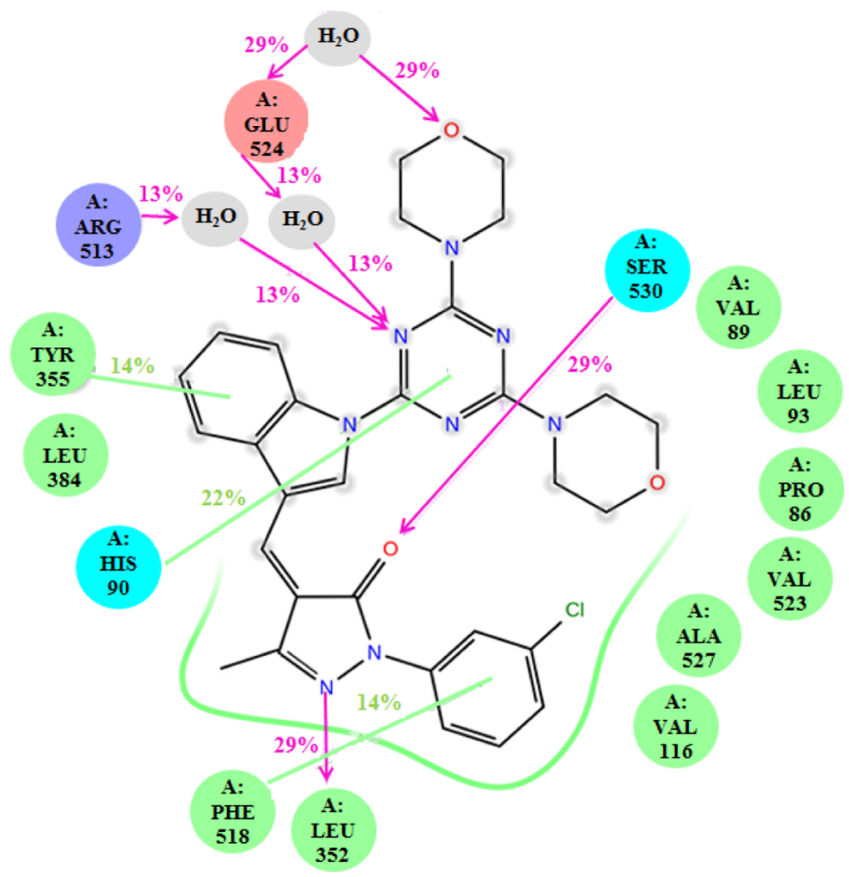

Figure 12. Interactions of compound 6 with the protein residues during evolution of trajectory $(0.00-50 \mathrm{~ns})$ that occur more than $10 \%$.

another through its carbonyl oxygen with S530 (2.35 ̊) were observed (Figure 14A). It also exhibited $\pi-\pi$ interactions between 1,3,5-triazine ring and Y355 and between the aromatic ring of oxindole part and W387 and Y385 of COX-2 (Figure $14 \mathrm{~A}, \mathrm{~B})$. The aromatic ring of indole was also involved in $\pi-\pi$ interactions with Y355 and F518 of COX-2.

2.6. NMR Experiments for Enzyme-Ligand Interactions. To corroborate the results of docking studies, solutionphase NMR experiments of compound $\mathbf{1 0}$ in the absence and presence of COX-2 were performed. ${ }^{1} \mathrm{H}$ chemical shift and spin-lattice relaxation time $\left(T_{1}\right)$ of various protons were measured by $1 \mathrm{D}{ }^{1} \mathrm{H}$ NMR and inversion recovery NMR experiments. The ${ }^{1} \mathrm{H}$ NMR spectrum of 10 (12 mM) was recorded in $0.5 \mathrm{~mL}$ of DMSO- $d_{6}$ at $25^{\circ} \mathrm{C}$ (blue trace, Figure

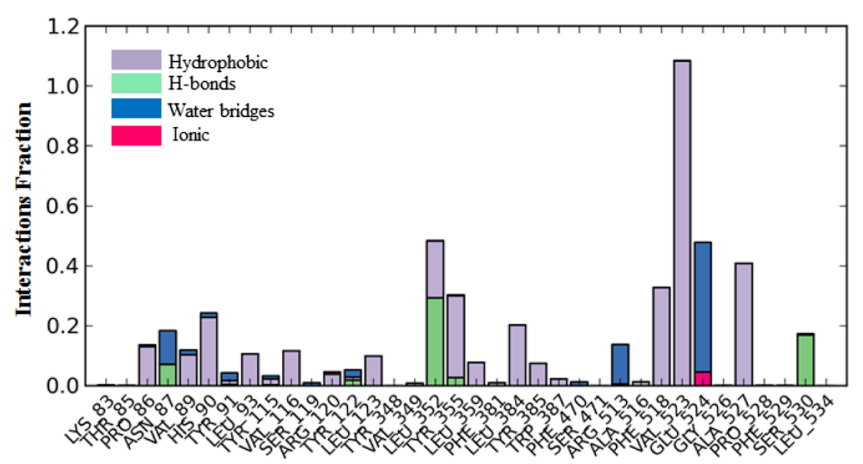

Figure 13. Interaction analysis between protein and compound 6 throughout the simulation over the period $0.00-50 \mathrm{~ns}$. The stacked bar charts were normalized throughout the trajectory.

$15)$. Addition of $5 \mu \mathrm{L}$ of COX-2 to the solution of compound 10 resulted in significant upfield shift of aromatic protons $\mathrm{H}-5$, $\mathrm{H}-9, \mathrm{H}-4$, and $\mathrm{H}-16$ (Figure 15), whereas no visible change in the $\mathrm{CH}_{2}$ protons of morpholine and piperidine ring was observed. These observations indicated that compound $\mathbf{1 0}$ interacts with COX-2. The protons $\mathrm{H}-5, \mathrm{H}-9, \mathrm{H}-4$, and $\mathrm{H}-16$ are probably under the shielding effect of hydrophobic residues of COX-2. The binding of compound with the enzyme was also confirmed by $T_{1}$ experiments where spin-lattice relaxation time $\left(T_{1}\right)$ of various protons of compound $\mathbf{1 0}$ was measured (Figure 16). Characteristically, supporting the chemical shifts data, the relaxation time of $\mathrm{H}-5, \mathrm{H}-9, \mathrm{H}-1, \mathrm{H}-4$, and $\mathrm{H}-16$ protons was considerably decreased in the presence of COX-2. Hence, the results of $\mathrm{T}_{1}$ measurement experiments indicated that an aromatic ring of indole and oxindole part of molecule $\mathbf{1 0}$ interacts with COX-2. All these protons were found to interact with the amino acid residues during the docking of compound 10 in the active site of COX-2 (Figure 17). Probably, these protons come under the shielding effect of the hydrophobic residues of the enzyme, and this was evident from the upfield shift of their resonance frequencies in the presence of the enzyme. Because of the less solubility of compound 6 in comparison to the solubility of $\mathbf{1 0}$ for NMR experiments, we did not perform ${ }^{1} \mathrm{H}$ NMR and $T_{1}$ experiments with 6 .

2.7. 3D-Quantitative Structure-Activity Relationship Study Model. Using partial least square (PLS) factor of two, the field-based 3D-quantitative structure-activity relationship (QSAR) model was generated by correlating the activity with steric, electrostatic, hydrophobic, hydrogen bond donor (HBD), and hydrogen bond acceptor (HBA) factors (Figures 18 and S205). Leave-one-out cross-validation and non-crossvalidation analysis gave $R^{2} C V$ and $R^{2} 0.66$ and 0.96 , respectively. The standard error of the estimate was 0.18 , and the $F$ ratio was 102.0 (Tables 6 and S3). It was observed that the steric, electrostatic, hydrophobic, HBA, and HBD fields contribute $0.46,0.093,0.209,0.227$, and 0.00 , respectively, for the activity of the compound. The green region in Figure 18a represents that bulky substituents are favorable for the activity, whereas the negative effect of the steric substituents is represented by the yellow region. The diagrammatic representation of the electrostatic factor is shown in Figure $18 \mathrm{~b}$ where the blue contours indicate electropositive groups that may increase the activity of the compound and the red region displays electronegative groups. Desirably, the electropositive region of compounds 6,12 , and 17 represented by $\mathrm{Ph}$ and $\mathrm{CH}_{3}$ groups falls in the blue region, whereas the electronegative part of nitrogens is placed in the red contours 

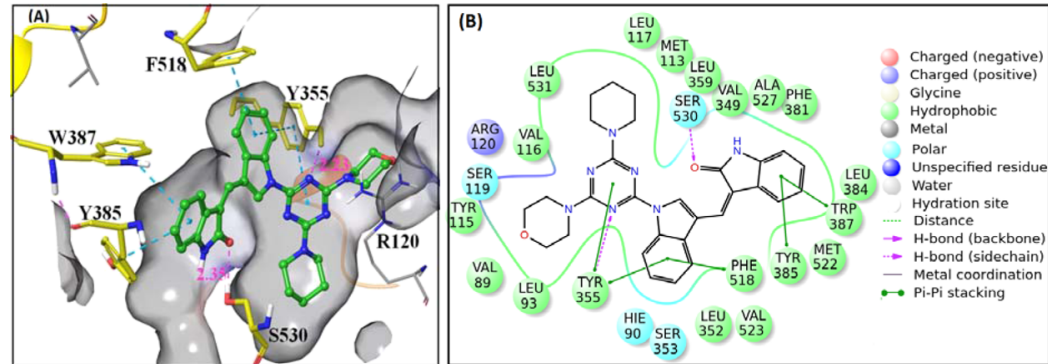

Figure 14. (A) Crystal coordinates of compound 10 and COX-2 active site (PDB ID 1CVU). (B) Interactions of compound 10 with the amino acids.

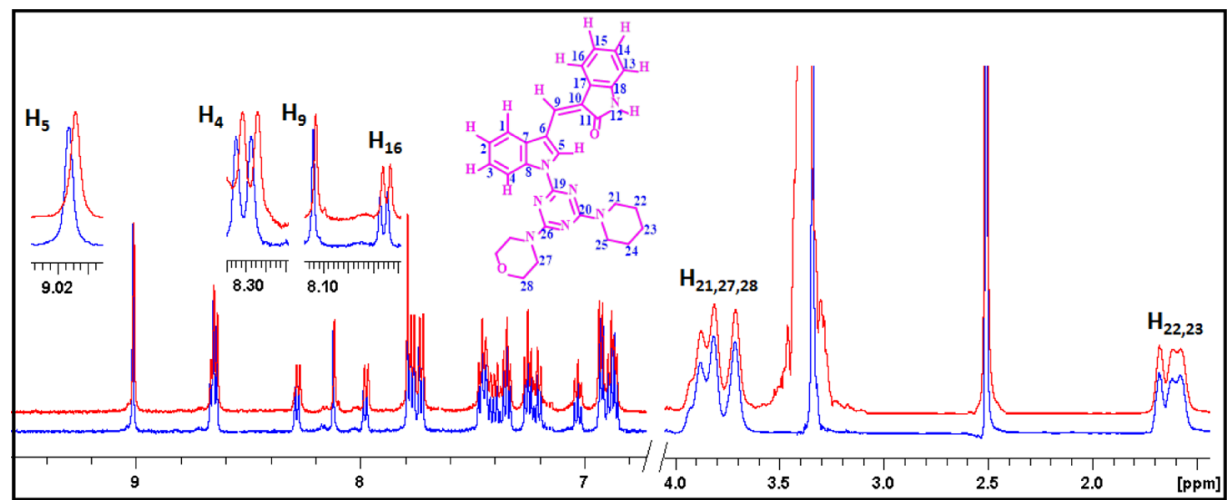

Figure 15. Part of ${ }^{1} \mathrm{H}$ NMR spectrum of compound 10 (blue trace) and compound 10 in the presence of COX-2 (red trace).

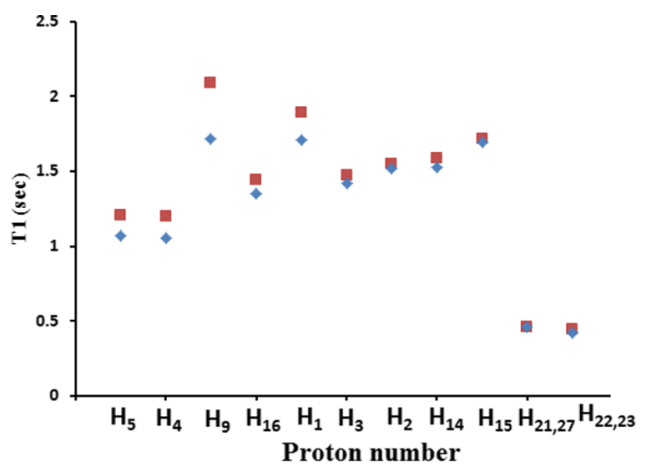

Figure 16. ${ }^{1} \mathrm{H} T_{1}$ relaxation times of compound $10(12 \mathrm{mM})$ in the absence (red dots) and presence (blue dots) of COX-2.

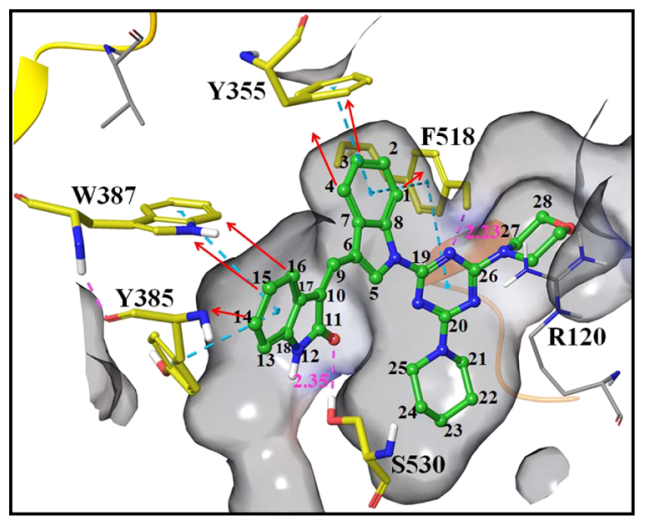

Figure 17. Compound 10 was positioned in the interacting pocket of COX-2 (PDB ID 1CVU). Arrows indicate the protons interacting with the amino acid residues. The same protons undergo change in the chemical shift and $T_{1}$ in the presence of COX-2.

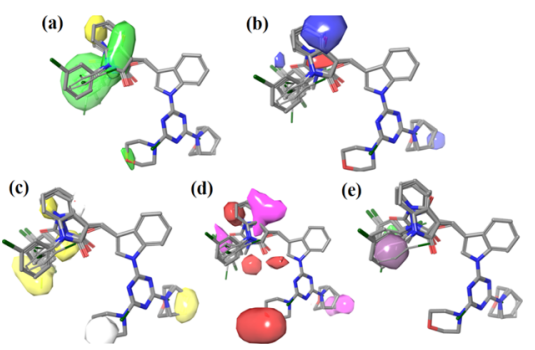

Figure 18. QSAR contour maps showing contribution of various descriptors: (a) steric factor-yellow represents negative saturation and green represents positive saturation; (b) electrostatic factor-blue indicates positive effect and red represents negative saturation; (c) hydrophobic contours-white region represents negative and yellow represents positive saturation; (d) HBA-magenta region shows negative effect and maroon indicates positive saturation; (e) HBDgreen represents negative saturation and blue-violet represents positive saturation. The molecules with better activity are shown in the form of a tube and inactive molecules in the form of thin wires.

of the map. In compounds 16 and 19, the electronegative oxygen part of the molecules lies in the unfavorable blue region, which might be leading to the decrease in their activity. The placement of Cl-phenyl/2,6-dichlorophenyl ring of compounds $3,6,9,12,18$, and 22 in the yellow contours might be responsible for the higher activity of these molecules (Figure 18c). The docked complex of compound 6 with COX-2 (Figure 10b) also shows the hydrophobic interaction through Cl-phenyl ring and hence complies to the comparative molecular field analysis (CoMFA) model of the compound. The red color in Figure 18d favors the HBA group/s, whereas the presence of HBA group/s in the magenta contours is disfavored and may lead to reduced activity. In most of our compounds, the nitrogen atom of triazine ring and carbonyl 
Table 6. PLS-Based Statistical Parameters for the Selected 3D-QSAR Model ${ }^{a}$

$\begin{array}{cccccccccccc}\text { PLS factors } & \mathrm{SD} & R^{2} & R^{2} C V & R^{2} \text { scramble } & \text { stability } & F & Q^{2} & \text { Pearson- } R \\ 1 & 0.4160 & 0.7322 & 0.5459 & 0.3537 & 0.955 & 32.8 & 9.49 \times 10^{-5} & 0.38 & 0.4999 & 0.7701 \\ 2 & 0.1899 & 0.9688 & 0.6599 & 0.6149 & 0.798 & 102 & 7.92 \times 10^{-8} & 0.27 & 0.7452 & 0.9163\end{array}$

${ }^{a} \mathrm{SD}$, standard deviation of regression; $R$, squared value of $R^{2}$ for the regression; $F$, variance ratio. Large value of $F$ indicates more statistical regression; $P$, significance level of variance ratio. Smaller value indicates a greater degree of confidence; rmse, root-mean-square error; $Q$ squared value of $Q^{2}$ for the predicted activities; Pearson- $R$, Pearson- $R$ value for the correlation between the predicted and observed activity for the test set.
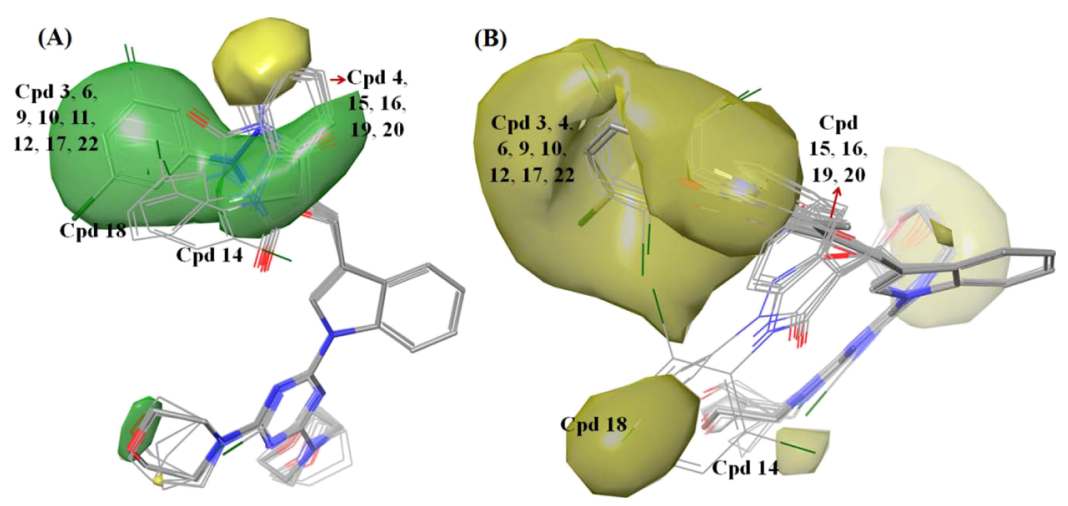

Figure 19. Steric (A) and hydrophobic (B) contour fields generated around all compounds.

oxygen is involved in hydrogen bonding with R120, S530, Y385, and Y355. Representing HBD contribution, the blueviolet region in Figure 18e favors the activity of the compound, whereas green color disfavors the activity. Because no HBD group is present in the blue contours, the contribution of $\mathrm{HBD}$ in the present CoMFA model is 0.00 .

Barring the HBD descriptor that was contributing equally in all the compounds, the collective role of steric and hydrophobic parameters is shown in Figure 19. The large green contour present at the center of Cl-phenyl ring and 2,6-dichlorophenyl ring shows steric contribution to the activity of compounds 3 , $6,9,10,11,17$, and 22, whereas in compound 14, 2,6dichlorophenyl ring did not fall in the green region. For the contribution of hydrophobicity, the favorable yellow region was found around the Cl-phenyl ring and 2,6-dichlorophenyl ring of compounds 3, 4, 6, 9, 10, 12, 17, and 22. Moreover, the hydrophobic contours partially overlap with sterically favorable region. Therefore, the COX-2 inhibitory activity of compounds $3,4,6,9,10,12,17$, and 22 seems to be influenced by the synergistic effect of steric and hydrophobic parameters.

Significant fitness between the experimental activity and the predicted activity of the training and test set was observed in the QSAR model (Table S3) (Figures 20 and 21). A common pharmacophore model was generated by aligning all the active and inactive ligands to the pharmacophore (Figure 22).

\section{CONCLUSIONS}

With the help of in vitro and in vivo experiments on a series of compounds, we were able to identify compound $\mathbf{6}$ as a new lead for anti-inflammatory drugs. Compound 6 exhibited $\mathrm{IC}_{50} 20$ $\mathrm{nM}$ and $K_{\mathrm{a}} 4.83 \times 10^{5} \mathrm{M}^{-1}$ for COX-2. The hydrophobic interactions of $\mathbf{6}$ with the enzyme were apparent from the change in chemical shifts and $T_{1}$ of aromatic protons. Significant analgesic and anti-inflammatory activity of compound 6 with minimum toxicity risk was observed over Swiss albino mice. We observed a close correlation between the results of solution-phase NMR experiments and the molecular modeling studies, which could be helpful for the further refinement of the structure of the molecule.

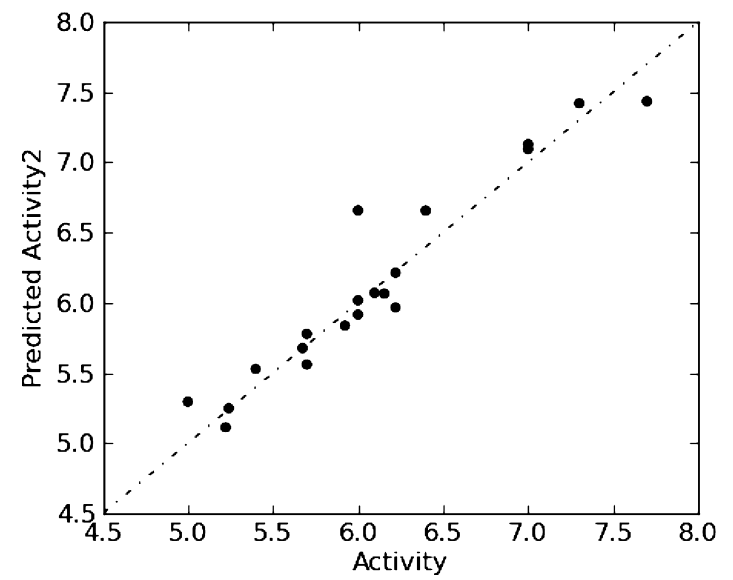

Figure 20. Scatter plot of observed versus predicted activity for training and test set compounds.

\section{EXPERIMENTAL SECTION}

4.1. General. Melting points of the solid compounds were determined in capillaries. Using $\mathrm{CDCl}_{3}$ and/or dimethyl sulfoxide (DMSO) $-d_{6}$ as the solvent and tetramethylsilane as the internal reference, ${ }^{1} \mathrm{H}$ and ${ }^{13} \mathrm{C}$ NMR spectra were recorded on Bruker 500 and $125 \mathrm{MHz}$ NMR spectrometers. The chemical shifts are in parts per million, and coupling constants are given in hertz. For representing the multiplicity of signals in ${ }^{1} \mathrm{H}$ NMR, s was used for singlet, $\mathrm{d}$ for doublet, dd for doubledoublet, $\mathrm{t}$ for triplet, and $\mathrm{m}$ for multiplet. A Bruker micrOTOF Q II mass spectrometer was used for recording mass spectra. All the compounds were procured as single geometrical isomer (Z-isomer) except in the case of compounds 9 and 14 where inseparable E- and Z-isomers were obtained in a 2:1 ratio. The purity of the compounds $(P \%)$ was assessed by the $\mathrm{q}^{1} \mathrm{H}$ NMR method (absolute $\mathrm{q}^{1} \mathrm{H}$ NMR with internal calibration), ${ }^{25}$ and it was $>98 \%$.

$$
[P \%]=n_{\mathrm{IC}} \cdot \operatorname{Int}_{\mathrm{t}} \cdot \mathrm{MW}_{\mathrm{t}} \cdot m_{\mathrm{IC}} / n_{\mathrm{t}} \cdot \mathrm{Int}_{\mathrm{IC}} \cdot \mathrm{MW}_{\mathrm{IC}} \cdot m_{\mathrm{s}} \times P_{\mathrm{IC}}
$$



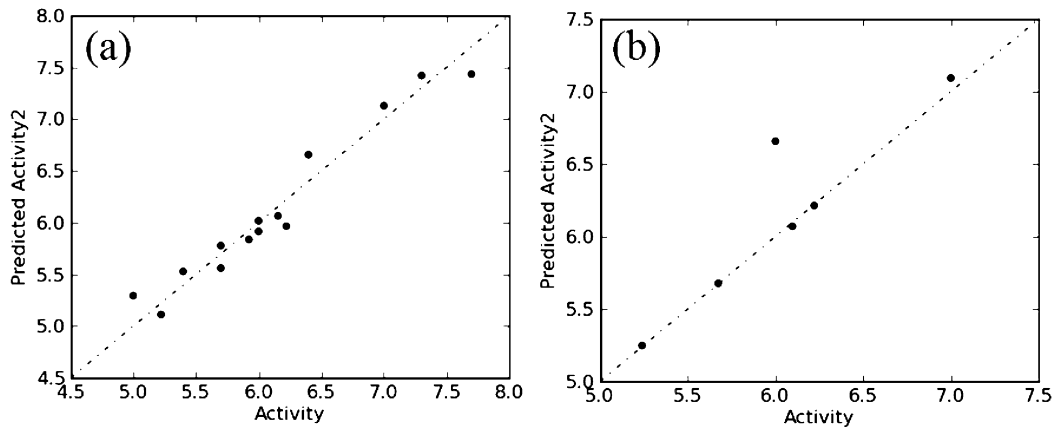

Figure 21. Plot between observed and predicted COX-2 inhibitory activity of training set (a) and test set molecules (b) using a field-based 3DQSAR model.

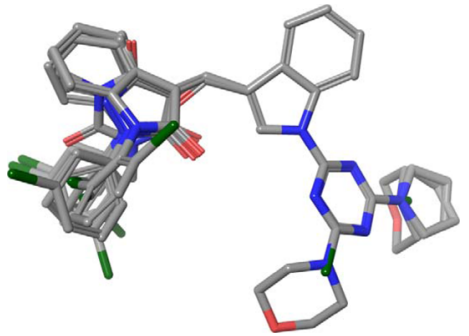

Figure 22. Alignment of all ligands (active and inactive) to the pharmacophore.

where MW is the molecular weight; $P$ is the purity of the internal calibrant; $m_{\mathrm{IC}}$ represents the amount of internal calibrant; $m_{\mathrm{s}}$ is the amount of sample (compound); Int is the integral; and $n$ is the number of protons for an NMR signal. IC is the internal calibrant, and $\mathrm{t}$ is the target analyte or compound.

4.1.1. Synthesis of Compounds $1 a$ and $1 b$. Cyanuric chloride $(1 \mathrm{~g}, 5.43 \mathrm{mmol})$ was taken in acetone $(40 \mathrm{~mL})$ at 0 ${ }^{\circ} \mathrm{C}$, and morpholine $(0.94 \mathrm{~g}, 10.86 \mathrm{mmol})$ was added dropwise followed by the addition of triethylamine $(1.09 \mathrm{~g}, 10.86 \mathrm{mmol})$. Then, the reaction mixture was stirred at $25-28{ }^{\circ} \mathrm{C}$ for $1 \mathrm{~h}$. The reaction was quenched with water and extracted with ethyl acetate $(4 \times 25 \mathrm{~mL})$. The organic layer was separated, dried over $\mathrm{Na}_{2} \mathrm{SO}_{4}$, and concentrated in vacuum to procure crude product that was column-chromatographed using ethyl acetate and hexane as eluents to procure products $\mathbf{1 a}$ and $\mathbf{1} \mathbf{b}$.

4.1.2. Synthesis of Compounds 3-6: General Procedure. Compounds 3-6 were prepared through Knoevenagel condensation of compound $2(1 \mathrm{mmol})$ with active methylene compounds including 1-(3-chlorophenyl)-3-methyl-2-pyrazolin-5-one; $N, N$-dimethylbarbituric acid; and oxindole and indolinone $(1 \mathrm{mmol})$ in the presence of piperidine in $\mathrm{CHCl}_{3}$ at $100{ }^{\circ} \mathrm{C}$ for $2 \mathrm{~h}$ under microwave irradiation. The completion of the reaction was monitored with thin-layer chromatography (TLC). After completion of the reaction, the reaction mixture was quenched with water and extracted with $\mathrm{CHCl}_{3}(4 \times 25$ $\mathrm{mL})$. The organic layer was separated, dried over $\mathrm{Na}_{2} \mathrm{SO}_{4}$, and concentrated in vacuum to procure crude product. The crude product was further purified by diethyl ether or by recrystallization in chloroform: methanol $(2: 8)$ to obtain compounds 3-6 with yield $80-85 \%$.

4.1.3. Synthesis of Compounds 9-12: General Procedure. Compounds 9-12 were prepared through Knoevenagel condensation of compound 7 (1 mmol) with active methylene compounds including 1-(3-chlorophenyl)-3-methyl-2-pyrazolin-5-one; $N, N$-dimethylbarbituric acid; and oxindole and indolinone $(1 \mathrm{mmol})$ in the presence of piperidine in $\mathrm{CHCl}_{3}$ at $100{ }^{\circ} \mathrm{C}$ for $2 \mathrm{~h}$ under microwave irradiation. After completion of the reaction (TLC), the reaction mixture was quenched with water and extracted with $\mathrm{CHCl}_{3}(4 \times 25 \mathrm{~mL})$. The chloroform layers were collected, dried over $\mathrm{Na}_{2} \mathrm{SO}_{4}$, and concentrated in vacuum to procure crude product that was purified by washing with ether or by recrystallization in chloroform: methanol $(2: 8)$ to obtain compounds 9-12 with yield $70-85 \%$.

4.1.4. Synthesis of Compounds 13-17: General Procedure. Compounds 13-17 were prepared by the reaction of compound 7 (1 mmol) with active methylene compounds including 1-(3-chlorophenyl)-3-methyl-2-pyrazolin-5-one; $\mathrm{N}, \mathrm{N}$ dimethylbarbituric acid; and oxindole and indolinone $(1 \mathrm{mmol})$ in the presence of pyrrolidine in $\mathrm{CHCl}_{3}$ at $100{ }^{\circ} \mathrm{C}$ for $2 \mathrm{~h}$ under microwave irradiation. After the reaction is completed (TLC), the reaction mixture was quenched with water and extracted with $\mathrm{CHCl}_{3}(4 \times 25 \mathrm{~mL})$. The chloroform part was dried over $\mathrm{Na}_{2} \mathrm{SO}_{4}$ and concentrated in vacuum to procure crude product. The crude product was further purified by washing with ether or by recrystallization in chloroform: methanol $(2: 8)$ to obtain compounds $13-17$ with yield $70-85 \%$.

4.1.5. Synthesis of Compounds 18-20: General Procedure. A finely ground mixture of $7(1 \mathrm{mmol})$ and 1-(3chlorophenyl)-3-methyl-2-pyrazolin-5-one/1,3-dimethyl barbituric acid/oxindole $(1 \mathrm{mmol})$ was heated at $155-160{ }^{\circ} \mathrm{C}$ for 25-30 min. After completion of the reaction (TLC), the crude reaction mass was washed with diethyl ether to procure pure compounds 18-20.

4.1.5.1. 2-Chloro-4,6-dimorpholino-1,3,5-triazine (1a). Compound 1a was procured as per the procedure given above. Colorless solid, yield $65 \%, \mathrm{mp} 175-176{ }^{\circ} \mathrm{C} .{ }^{1} \mathrm{H}$ NMR $\left(500 \mathrm{MHz}, \mathrm{CDCl}_{3}\right): \delta 3.70-3.80\left(\mathrm{~m}, 16 \mathrm{H}, 8 \times \mathrm{CH}_{2}\right) \cdot{ }^{13} \mathrm{C}$ NMR $\left(125 \mathrm{MHz}, \mathrm{CDCl}_{3}\right): \delta 43.86\left(-\mathrm{ve}, \mathrm{CH}_{2}\right), 66.53$ (-ve, $\mathrm{CH}_{2}$ ), 66.71 (-ve, $\mathrm{CH}_{2}$ ), 164.48 (ab, ArC), 169.69 (ab, ArC). HRMS (microTOF-QII, MS, ESI): calcd for $\mathrm{C}_{11} \mathrm{H}_{16} \mathrm{~N}_{5} \mathrm{O}_{2} \mathrm{Cl}$ $\left([\mathrm{M}+\mathrm{H}]^{+}\right), 286.1065$; found, 286.1049.

4.1.5.2. 2,4-Dichloro-6-morpholino-1,3,5-triazine (1b). Compound $\mathbf{1 b}$ was procured as per the procedure given above. Colorless solid, yield $30 \%, \mathrm{mp} 161-162{ }^{\circ} \mathrm{C} .{ }^{1} \mathrm{H}$ NMR $\left(500 \mathrm{MHz} \mathrm{CDCl}_{3}\right): \delta 3.76\left(\mathrm{t}, 4 \mathrm{H}, J=9.82 \mathrm{~Hz}, 2 \times \mathrm{CH}_{2}\right), 3.90$ $\left(\mathrm{t}, 4 \mathrm{H}, J=9.82 \mathrm{~Hz}, 2 \times \mathrm{CH}_{2}\right) \cdot{ }^{13} \mathrm{C} \mathrm{NMR}\left(125 \mathrm{MHz} \mathrm{CDCl}_{3}\right): \delta$ 44.47 (-ve, $\mathrm{CH}_{2}$ ), 66.38 (-ve, $\mathrm{CH}_{2}$ ), 164.10 (ab, $\mathrm{ArC}$ ), 170.44 (ab, ArC). HRMS (ESI): calcd for $\mathrm{C}_{7} \mathrm{H}_{8} \mathrm{~N}_{4} \mathrm{OCl}_{2}\left([\mathrm{M}+\mathrm{H}]^{+}\right)$, 235.0147; found, 235.0123 .

4.1.5.3. 1-(4,6-Dimorpholino-1,3,5-triazin-2-yl)-1H-indole3-carbaldehyde (2). $\mathrm{NaH}(1.2 \mathrm{mmol})$ was washed 3-4 times with dry hexane for the removal of paraffin coating, and then it 
was suspended in dry ACN (20 mL). Indole-3-carboxaldehyde (1 mmol) was added to $\mathrm{NaH}$ suspension in $\mathrm{ACN}$, and the reaction mixture was stirred at $0{ }^{\circ} \mathrm{C}$ for $5-10 \mathrm{~min}$ until the whole reactant gets dissolved. Then, compound $1 \mathrm{a}(1.2 \mathrm{mmol})$ was added with continuous stirring. On completion of the reaction (TLC), the reaction was quenched by adding ice cold water. The reaction mixture was extracted with ethyl acetate. After drying over anhydrous $\mathrm{Na}_{2} \mathrm{SO}_{4}$, ethyl acetate was removed under vacuum. The residue was column-chromatographed by using ethyl acetate-hexane as eluents to procure pure product 2 . Colorless solid, yield $76 \%$, mp $244-245^{\circ} \mathrm{C}$. IR (KBr): 3135, 2961, 2902, 2860, 1730, 1684, $1571 \mathrm{~cm}^{-1} .{ }^{1} \mathrm{H}$ NMR (500 MHz, $\left.\mathrm{CDCl}_{3}\right): \delta 3.82-3.95\left(\mathrm{~m}, 16 \mathrm{H}, 8 \times \mathrm{CH}_{2}\right)$, $7.41-7.44$ (m, 2H, ArH), 8.35 (d, $1 \mathrm{H}, J=7.18 \mathrm{~Hz}, \mathrm{ArH}), 8.61$ (d, $1 \mathrm{H}, J=7.99 \mathrm{~Hz}, \mathrm{ArH}), 8.84(\mathrm{~s}, 1 \mathrm{H}, \mathrm{CH}), 10.16(\mathrm{~s}, 1 \mathrm{H}$, $\mathrm{CHO}) .{ }^{13} \mathrm{C}$ NMR $\left(125 \mathrm{MHz}, \mathrm{CDCl}_{3}\right): \delta 43.93\left(-\mathrm{ve}, \mathrm{CH}_{2}\right)$, 66.73 (-ve, $\mathrm{CH}_{2}$ ), 116.30 (+ve, $\left.\mathrm{ArCH}\right), 120.74(\mathrm{ab}, \mathrm{ArC})$, 122.02 (+ve, $\mathrm{ArCH}$ ), 124.10 (+ve, $\mathrm{ArCH}$ ), 125.29 (+ve, $\operatorname{ArCH}), 127.01$ (ab, ArC), 136.33 (ab, ArC), 136.82 (+ve, $\mathrm{ArCH}), 162.74$ (ab, ArC), 165.13 (ab, ArC), $185.82(\mathrm{C}=\mathrm{O})$. HRMS (ESI): calcd for $\mathrm{C}_{20} \mathrm{H}_{22} \mathrm{~N}_{6} \mathrm{O}_{3}\left([\mathrm{M}+\mathrm{H}]^{+}\right), 395.1826$; found, 395.1819 .

4.1.5.4. (Z)-1-(2,6-Dichlorophenyl)-3-((1-(4,6-dimorpholino-1,3,5-triazin-2-yl)1H-indolyl)methylene)indolin-2-one (3). According to the general procedure given above, compound 3 was procured by the reaction of compound 2 and 1-(2,6dichlorophenyl)indolin-2-one. Yellow solid, yield $80 \%, \mathrm{mp}>$ $300{ }^{\circ} \mathrm{C}$. IR (KBr): 3174, 3052, 1607, 1570, $1407 \mathrm{~cm}^{-1} .{ }^{1} \mathrm{H}$ NMR (500 MHz, $\left.\mathrm{CDCl}_{3}\right): \delta 3.79-3.96\left(\mathrm{~m}, 16 \mathrm{H}, 8 \times \mathrm{CH}_{2}\right)$, $6.46(\mathrm{~d}, 1 \mathrm{H}, J=7.63 \mathrm{~Hz}, \mathrm{ArH}), 7.17(\mathrm{t}, 1 \mathrm{H}, J=7.60 \mathrm{~Hz}, \mathrm{ArH})$, $7.23(\mathrm{t}, 1 \mathrm{H}, J=7.60 \mathrm{~Hz}, \mathrm{ArH}), 7.39-7.42(\mathrm{~m}, 3 \mathrm{H}, \mathrm{ArH}), 7.54-$ 7.57 (m, 2H, ArH), 7.77 (d, 1H, J = 7.23 Hz, ArH), 7.93-7.94 (m, $1 \mathrm{H}, \operatorname{ArH}), 8.03(\mathrm{~s}, 1 \mathrm{H}$, bridged $\mathrm{H}), 8.65-8.67(\mathrm{~m}, 1 \mathrm{H}$, $\mathrm{ArH}), 10.23$ (s, 1H, CH). ${ }^{13} \mathrm{C}$ NMR $\left(125 \mathrm{MHz}, \mathrm{CDCl}_{3}\right): \delta$ 43.98 (-ve, $\mathrm{CH}_{2}$ ), 66.80 (-ve, $\mathrm{CH}_{2}$ ), 108.85 (+ve, $\mathrm{ArCH}$ ), 113.83 (ab, C), 116.61 (+ve, $\operatorname{ArCH}), 117.88$ (+ve, $\mathrm{ArCH}$ ), 118.72 (+ve, $\mathrm{ArCH}$ ), 121.68 (ab, ArC), 122.28 (+ve, $\mathrm{ArCH}$ ), 122.88 (+ve, $\mathrm{ArCH}$ ), 124.19 (+ve, $\mathrm{ArCH}$ ), 126.40 (+ve, $\mathrm{ArCH}$ ), 127.85 (+ve, $\mathrm{ArCH}), 128.89$ (ab, ArC), 129.02 (+ve, $\mathrm{ArCH}), 129.13$ (+ve, $\mathrm{ArCH}), 130.42$ (+ve, $\mathrm{ArCH}), 131.25$ (ab, ArC), 133.76 (+ve, $\operatorname{ArCH}), 135.46(\mathrm{ab}, \mathrm{ArC}), 136.06(\mathrm{ab}$, $\operatorname{ArC}), 139.75$ ( $a b, \operatorname{ArC}), 163.01(a b, \operatorname{ArC}), 165.27(\mathrm{C}=\mathrm{O})$. HRMS (ESI): calcd for $\mathrm{C}_{34} \mathrm{H}_{29} \mathrm{~N}_{7} \mathrm{O}_{3} \mathrm{Cl}_{2}\left([\mathrm{M}+\mathrm{H}]^{+}\right), 654.1781$; found, 654.1768 .

4.1.5.5. (Z)-3-((1-(4,6-Dimorpholino-1,3,5-triazin-2-yl)-1Hindol-3-yl)methylene)indolin-2-one (4). As per the general procedure given above, compound 4 was synthesized by using 2 and indolin-2-one. Yellow solid, yield $82 \%, \mathrm{mp}>300{ }^{\circ} \mathrm{C}$. IR (KBr): 3430, 3127, 3064, 1697, 1605, $1410 \mathrm{~cm}^{-1} .{ }^{1} \mathrm{H}$ NMR $\left(500 \mathrm{MHz}, \mathrm{CDCl}_{3}\right): \delta 4.01-4.07\left(\mathrm{~m}, 16 \mathrm{H}, 8 \times \mathrm{CH}_{2}\right), 7.00(\mathrm{t}$, $1 \mathrm{H}, J=7.60 \mathrm{~Hz}, \mathrm{ArH}), 7.14(\mathrm{~d}, 1 \mathrm{H}, J=7.97 \mathrm{~Hz}, \operatorname{ArH}), 7.35(\mathrm{t}$, $1 \mathrm{H}, J=8.64 \mathrm{~Hz}, \operatorname{ArH}), 7.48(\mathrm{t}, 1 \mathrm{H}, J=7.60 \mathrm{~Hz}, \operatorname{ArH}), 7.54(\mathrm{t}$, $1 \mathrm{H}, J=7.60 \mathrm{~Hz}, \mathrm{ArH}), 7.72-7.77(\mathrm{~m}, 2 \mathrm{H}, \mathrm{ArH}), 8.07(\mathrm{~s}, 1 \mathrm{H}$, $\mathrm{NH}), 8.41(\mathrm{~d}, 1 \mathrm{H}, J=8.41 \mathrm{~Hz}, \operatorname{ArH}), 8.69(\mathrm{~s}, 1 \mathrm{H}$, bridged $\mathrm{H})$, $9.73(\mathrm{~s}, 1 \mathrm{H}, \mathrm{CH}) .{ }^{13} \mathrm{C} \mathrm{NMR}\left(125 \mathrm{MHz}, \mathrm{CDCl}_{3}\right): \delta 45.72$ (-ve, $\mathrm{CH}_{2}$ ), 65.97 (-ve, $\mathrm{CH}_{2}$ ) 110.93 (ab, $\mathrm{ArC}$ ), 111.91 (+ve, $\mathrm{ArH}$ ), 113.19 (ab, ArC), 115.46 (ab, ArC), 116.36 (+ve, ArH), 117.72 (ab, ArC), 118.39 (ab, ArC), 120.83 (+ve, ArH), 121.52 (ab, ArC), 123.28 (+ve, ArH), 125.23 (+ve, ArH), 126.45 (+ve, $\mathrm{ArH}), 127.12$ (ab, ArC), 127.70 (+ve, ArH), 130.08 (+ve, $\operatorname{ArH}$ ), 130.17 (ab, ArC), 130.50 (+ve, ArH), 135.33 (ab, ArC), 140.10 (ab, ArC), 157.13 (ab, ArC), 159.63 (ab, ArC), 160.60 (ab, ArC), 160.94 (ab, ArC), 161.02 (ab, ArC), 161.28 (ab,
$\operatorname{ArC}), 161.36(\mathrm{ab}, \operatorname{ArC}), 161.62(\mathrm{ab}, \operatorname{ArC}), 161.70(\mathrm{C}=\mathrm{O})$, 172.31 (ab, ArC). HRMS (ESI): calcd for $\mathrm{C}_{28} \mathrm{H}_{27} \mathrm{~N}_{7} \mathrm{O}_{3}([\mathrm{M}+$ $\left.\mathrm{H}]^{+}\right)$, 510.2248; found, 510.2234.

4.1.5.6. 1,3-Dimethyl-5-((1-(4,6-dimorpholino-1,3,5-triazin-2-yl)-1H-indol-3-yl)methylene)pyrimidine-2,4,6(1,3,5H)trione (5). In accordance to the general procedure given above, compound 5 was synthesized by using 2 and 1,3-dimethyl barbituric acid. Yellow solid, yield $80 \%, \mathrm{mp}>300{ }^{\circ} \mathrm{C}$. IR (KBr): 3194, 2983, 2840, 1662, 1572, $1496 \mathrm{~cm}^{-1} .{ }^{1} \mathrm{H}$ NMR $\left(500 \mathrm{MHz}, \mathrm{CDCl}_{3}\right): \delta 3.45\left(\mathrm{~s}, 3 \mathrm{H}, \mathrm{CH}_{3}\right), 3.46\left(\mathrm{~s}, 3 \mathrm{H}, \mathrm{CH}_{3}\right)$, 3.84-4.01 (m, 16H, $\left.8 \times \mathrm{CH}_{2}\right), 7.42-7.45(\mathrm{~m}, 2 \mathrm{H}, \mathrm{ArH})$, 7.96-7.98 (m, 1H, ArH), 8.63-8.64 (m, 1H, ArH), 8.99 (s, $1 \mathrm{H}$, bridged $\mathrm{H}), 10.43(\mathrm{~s}, 1 \mathrm{H}, \mathrm{CH}) .{ }^{13} \mathrm{C}$ NMR $(125 \mathrm{MHz}$, $\mathrm{CDCl}_{3}$ ): $\delta 28.19$ (+ve, $\left.\mathrm{CH}_{3}\right), 28.92\left(+\mathrm{ve}, \mathrm{CH}_{3}\right), 43.93$ (-ve, $\mathrm{CH}_{2}$ ), 44.12 (-ve, $\mathrm{CH}_{2}$ ), 66.76 (-ve, $\mathrm{CH}_{2}$ ), 112.24 (ab, $\left.\mathrm{ArC}\right)$, 113.84 (ab, ArC), 116.69 (+ve, $\mathrm{ArCH}), 118.31$ (+ve, $\mathrm{ArCH}$ ), 123.88 (+ve, $\operatorname{ArCH}$ ), 124.95 (+ve, $\operatorname{ArCH}$ ), 131.76 (ab, $\operatorname{ArC}$ ), 135.64 (ab, ArC), 139.01 (+ve, $\mathrm{ArCH}$ ), 146.25 (+ve, $\mathrm{ArCH}$ ), 151.65 (ab, ArC), $161.50(\mathrm{ab}, \operatorname{ArC}), 162.91(\mathrm{C}=\mathrm{O}), 163.37$ $(\mathrm{C}=\mathrm{O})$. HRMS (ESI): calcd for $\mathrm{C}_{26} \mathrm{H}_{28} \mathrm{~N}_{8} \mathrm{O}_{5}\left([\mathrm{M}+\mathrm{Na}]^{+}\right)$, 555.2074; found, 555.2131.

4.1.5.7. (4Z)-1-(3-Chlorophenyl)-3-methyl-4-((1-(4,6-dimorpholino-1,3,5-triazin-2-yl)-1H-indol-3-yl)methylene)- $1 \mathrm{H}$ pyrazol-5(4H)-one (6). Using the general procedure given above, compound 6 was synthesized from 2 and 1-(3chlorophenyl)-3-methyl-1H-pyrazol-5(4H)-one. Yellow solid, yield $85 \%$, mp > $300{ }^{\circ} \mathrm{C}$. IR (KBr): 3158, 3040, 2894, 1681, 1593, 1569, $1390 \mathrm{~cm}^{-1} .{ }^{1} \mathrm{H}$ NMR $\left(500 \mathrm{MHz}, \mathrm{CDCl}_{3}\right): \delta 2.59$ (s, $\left.3 \mathrm{H}, \mathrm{CH}_{3}\right), 4.00-4.06\left(\mathrm{~m}, 16 \mathrm{H}, 8 \times \mathrm{CH}_{2}\right), 7.37-7.38(\mathrm{~m}$, $1 \mathrm{H}, \mathrm{ArH}), 7.43(\mathrm{t}, 1 \mathrm{H}, J=8.14 \mathrm{~Hz}, \operatorname{ArH}), 7.52-7.56(\mathrm{~m}, 3 \mathrm{H}$, ArH), 7.73 (s, 1H, ArH), 7.93-7.95 (m, 1H, ArH), 8.12 (s, 1H, bridged $\mathrm{H}), 8.47-8.49(\mathrm{~m}, 1 \mathrm{H}, \mathrm{ArH}), 10.55(\mathrm{~s}, 1 \mathrm{H}, \mathrm{CH}) .{ }^{13} \mathrm{C}$ NMR (125 MHz, $\mathrm{CDCl}_{3}$ ): $\delta 12.35$ (+ve, $\mathrm{CH}_{3}$ ), 44.89 (-ve, $\mathrm{CH}_{2}$ ), 66.31 (-ve, $\mathrm{CH}_{2}$ ), 110.95 (ab, ArC), 113.22 (ab, ArC), 115.49 (ab, ArC), 116.31 (ab, ArC), 116.72 (+ve, $\mathrm{ArCH}$ ), 117.75 (ab, ArC), 118.38 (+ve, ArCH), 120.59 (+ve, $\mathrm{ArCH}$ ), 121.35 (ab, ArC), 122.93 (+ve, $\mathrm{ArCH}), 125.46$ (+ve, $\mathrm{ArCH}$ ), 126.48 (+ve, $\mathrm{ArCH}$ ), 127.89 (+ve, $\mathrm{ArCH}), 130.09$ (ab, ArC), 130.35 (+ve, $\operatorname{ArCH}$ ), 134.98 (ab, $\operatorname{ArC}$ ), 135.67 (ab, $\operatorname{ArC}$ ), 136.70 (ab, ArC), 139.49 (+ve, $\mathrm{ArCH}$ ), 140.44 (+ve, $\mathrm{ArCH}$ ), $153.05(\mathrm{ab}, \mathrm{ArC}), 162.46(\mathrm{C}=\mathrm{O})$. HRMS (ESI): calcd for $\mathrm{C}_{30} \mathrm{H}_{29} \mathrm{~N}_{8} \mathrm{O}_{3} \mathrm{Cl}\left([\mathrm{M}+\mathrm{H}]^{+}\right)$, 585.2123; found, 585.2156.

4.1.5.8. 1-(4-Chloro-6-morpholino-1,3,5-triazin-2-yl)-1Hindole-3-carbaldehyde (7). After washing 3-4 times with dry hexane, $\mathrm{NaH}(1.22 \mathrm{mmol})$ was suspended in dry ACN (20 $\mathrm{mL}$ ). To this suspension, $1 \mathrm{mmol}$ indole-3-carboxaldehyde was added and stirred at $0{ }^{\circ} \mathrm{C}$ for 5-10 min until the whole reactant was dissolved. Compound $\mathbf{1 b}(1.2 \mathrm{mmol})$ was added to the above reaction mixture, and it was stirred continuously. On completion of the reaction (TLC), ice cold water was added and washed with ethyl acetate. The combined organic layers were dried over anhydrous $\mathrm{Na}_{2} \mathrm{SO}_{4}$ and concentrated under vacuum. The residue was column-chromatographed by using ethyl acetate-hexane as eluents to procure pure product 7 . White solid, yield $65 \%, \mathrm{mp} 235-236{ }^{\circ} \mathrm{C}$. IR (KBr): 3146, 2959, 2899, 2858, 1678, 1573, $1460 \mathrm{~cm}^{-1}$. ${ }^{1} \mathrm{H}$ NMR (500 MHz, $\left.\mathrm{CDCl}_{3}\right): \delta 3.83\left(\mathrm{t}, 2 \mathrm{H}, J=4.76 \mathrm{~Hz}, \mathrm{CH}_{2}\right), 3.88(\mathrm{t}, 2 \mathrm{H}, J=4.39$ $\left.\mathrm{Hz}, \mathrm{CH}_{2}\right), 3.98-4.02\left(\mathrm{~m}, 4 \mathrm{H}, 2 \times \mathrm{CH}_{2}\right), 7.41-7.46(\mathrm{~m}, 2 \mathrm{H}$, ArH), 8.34 (d, 1H, J = $7.63 \mathrm{~Hz}, \operatorname{ArH}), 8.57$ (d, $1 \mathrm{H}, J=8.12 \mathrm{~Hz}$, $\mathrm{ArH}), 8.78$ (s, 1H, CH), 10.15 (s, $1 \mathrm{H}, \mathrm{CHO}) .{ }^{13} \mathrm{C}$ NMR $(125$ $\mathrm{MHz}, \mathrm{CDCl}_{3}$ ): $\delta 44.4\left(-\mathrm{ve}, \mathrm{CH}_{2}\right.$ ), 44.5 (-ve, $\mathrm{CH}_{2}$ ), 66.2 (-ve, $\mathrm{CH}_{2}$ ), 66.5 (-ve, $\mathrm{CH}_{2}$ ), 116.5 (+ve, $\mathrm{ArCH}$ ), 122.1 (+ve, $\mathrm{ArCH}), 122.3$ (+ve, $\mathrm{ArCH}$ ), 124.9 (+ve, $\mathrm{ArCH}$ ), 126.0 (+ve, 
$\mathrm{ArCH}), 127.1$ (ab, ArC), 136.0 (ab, ArC), 136.2 (+ve, $\mathrm{ArCH})$, 162.6 (ab, ArC), 164.6 (ab, ArC), 170.5 (ab, ArC), $185.7(\mathrm{C}=$ O). HRMS (ESI): calcd for $\mathrm{C}_{16} \mathrm{H}_{14} \mathrm{~N}_{5} \mathrm{O}_{2} \mathrm{Cl}\left([\mathrm{M}+\mathrm{H}]^{+}\right)$ 344.0908; found, 344.0938 .

4.1.5.9. 1-(4-Morpholino-6-(piperidin-1-yl)-1,3,5-triazin-2yl)-1H-indole-3-carbaldehyde (8). Compound 8 was prepared by the nucleophilic substitution of chlorine of compound 7 (1 $\mathrm{mmol}$ ) with piperidine by performing the reaction in $\mathrm{CHCl}_{3}$ at $100{ }^{\circ} \mathrm{C}$ for $0.5 \mathrm{~h}$ under microwave irradiation. After completion of the reaction (TLC), water was added to the reaction mixture and washed with $\mathrm{CHCl}_{3}(4 \times 25 \mathrm{~mL})$. The combined organic layers were dried over $\mathrm{Na}_{2} \mathrm{SO}_{4}$ and concentrated in vacuum to procure crude product. The crude product was further purified by washing with ether to obtain pure compound 8 . Creamish white solid, yield $75 \%$, mp $236-237{ }^{\circ} \mathrm{C}$. IR ( $\left.\mathrm{KBr}\right): 3143,2939$, 2854, 1667, 1591, 1572, 1444, $1408 \mathrm{~cm}^{-1} .{ }^{1} \mathrm{H}$ NMR (500 MHz, $\left.\mathrm{CDCl}_{3}\right): \delta 1.68-1.75\left(\mathrm{~m}, 6 \mathrm{H}, 3 \times \mathrm{CH}_{2}\right), 3.82-3.92(\mathrm{~m}, 12 \mathrm{H}, 6$ $\left.\times \mathrm{CH}_{2}\right), 7.36-7.44(\mathrm{~m}, 2 \mathrm{H}, \mathrm{ArH}), 8.34(\mathrm{~d}, 1 \mathrm{H}, J=7.37 \mathrm{~Hz}$, $\mathrm{ArH}), 8.64$ (d, $1 \mathrm{H}, J=8.19 \mathrm{~Hz}, \mathrm{ArH}), 8.86(\mathrm{~s}, 1 \mathrm{H}, \mathrm{CH}), 10.16$ (s, 1H, CHO). ${ }^{13} \mathrm{C}$ NMR $\left(125 \mathrm{MHz} \mathrm{CDCl}_{3}\right): \delta 24.7$ (-ve, $\mathrm{CH}_{2}$ ), 25.7 (-ve, $\mathrm{CH}_{2}$ ), 43.9 (-ve, $\mathrm{CH}_{2}$ ), 44.5 (-ve, $\mathrm{CH}_{2}$ ), 44.8 (-ve, $\mathrm{CH}_{2}$ ), 66.7 (-ve, $\mathrm{CH}_{2}$ ), 116.3 (+ve, $\left.\mathrm{ArCH}\right), 120.5$ (ab, ArC), 121.9 (+ve, $\mathrm{ArCH}$ ), 123.9 (+ve, $\mathrm{ArCH}$ ), 125.1 (+ve, $\mathrm{ArCH}), 126.9$ (ab, ArC), 136.4 (ab, ArC), 137.0 (+ve, $\mathrm{ArCH}$ ), 162.7 (ab, ArC), $165.3(\mathrm{ab}, \operatorname{ArC}), 185.8(\mathrm{C}=\mathrm{O})$. HRMS (ESI): calcd for $\mathrm{C}_{21} \mathrm{H}_{24} \mathrm{~N}_{6} \mathrm{O}_{2}\left([\mathrm{M}+\mathrm{H}]^{+}\right)$, 393.2033; found, 393.2022.

4.1.5.10. (Z)-1-(2,6-Dichlorophenyl)-3-((1-(4-morpholino6-(piperidin-1-yl)-1,3,5-triazin-2-yl)- $1 \mathrm{H}$-indol-3-yl)methylene)indolin-2-one (9). Compound 9 was synthesized as two inseparable Z- and E-isomers (1:2, ${ }^{1} \mathrm{H}$ NMR) according to the general procedure given above using compound 7 and 1(2,6-dichlorophenyl)indolin-2-one. Yellow solid, yield 73\%, mp $>300{ }^{\circ} \mathrm{C}$. IR (KBr): 3170, 3051, 2933, 2852, 1717, 1608, 1570, 1445, 1406, $1361 \mathrm{~cm}^{-1} .{ }^{1} \mathrm{H} \mathrm{NMR}\left(500 \mathrm{MHz}, \mathrm{CDCl}_{3}\right): \delta 1.70-$ $1.75\left(\mathrm{~m}, 9 \mathrm{H}, 3 \times \mathrm{CH}_{2(\text { maj })}+3 \times \mathrm{CH}_{2(\min )}\right), 3.78-3.94(\mathrm{~m}$, $\left.18 \mathrm{H}, 6 \times \mathrm{CH}_{2(\text { maj })}+6 \times \mathrm{CH}_{2(\min )}\right), 6.45-6.47(\mathrm{~m}, 1 \mathrm{H}$, $\left.\mathrm{ArH}_{\text {min }}\right), 6.48-6.49\left(\mathrm{~m}, 1 \mathrm{H}, \mathrm{ArH}_{\mathrm{maj}}\right), 7.00(\mathrm{t}, 1 \mathrm{H}, J=7.70 \mathrm{~Hz}$, $\left.\mathrm{ArH}_{\text {maj }}\right), 7.17\left(\mathrm{t}, 1 \mathrm{H}, J=7.7 \mathrm{~Hz}, \mathrm{ArH}_{\text {min }}\right), 7.22(\mathrm{t}, 2 \mathrm{H}, J=7.7$ $\left.\mathrm{Hz}, \mathrm{ArH}_{\text {maj }}+\mathrm{ArH}_{\text {min }}\right), 7.35-7.38$ (m, 1H, $\left.\mathrm{ArH}_{\text {maj }}\right), 7.39-7.49$ $\left(\mathrm{m}, 4 \mathrm{H}, 2 \times \mathrm{ArH}_{\text {maj }}+2 \times \mathrm{ArH}_{\text {min }}\right), 7.54-7.57$ (m, 4H, $2 \times$ $\left.\mathrm{ArH}_{\text {maj }}+2 \times \mathrm{ArH}_{\text {min }}\right), 7.76\left(\mathrm{~d}, 1 \mathrm{H}, J=7.4 \mathrm{~Hz}, \operatorname{ArH}_{\text {min }}\right), 7.82$ $\left(\mathrm{d}, 1 \mathrm{H}, J=8.08 \mathrm{~Hz}, \mathrm{ArH}_{\text {maj }}\right), 7.92-7.94\left(\mathrm{~m}, 1 \mathrm{H}, \mathrm{ArH}_{\text {min }}\right), 8.04$ (s, $1 \mathrm{H}$, bridged $\mathrm{H}_{\text {min }}$ ), 8.13 (d, $1 \mathrm{H}, J=8.08 \mathrm{~Hz}, \mathrm{ArH}_{\text {maj }}$ ), 8.21 (s, $1 \mathrm{H}$, bridged $\left.\mathrm{H}_{\text {maj }}\right), 8.71\left(\mathrm{~d}, 2 \mathrm{H}, J=8.08 \mathrm{~Hz}, \mathrm{ArH}_{\text {maj }}+\right.$ $\left.\mathrm{ArH}_{\text {min }}\right), 9.11\left(\mathrm{~s}, 1 \mathrm{H}, \mathrm{CH}_{\text {maj }}\right), 10.23\left(\mathrm{~s}, 1 \mathrm{H}, \mathrm{CH}_{\text {min }}\right) .{ }^{13} \mathrm{C} \mathrm{NMR}$ $\left(125 \mathrm{MHz}, \mathrm{CDCl}_{3}\right): \delta 24.8$ (-ve, $\left.\mathrm{CH}_{2}\right), 25.8\left(-\mathrm{ve}, \mathrm{CH}_{2}\right), 43.8$ (-ve, $\mathrm{CH}_{2}$ ), 44.5 (-ve, $\mathrm{CH}_{2}$ ), 44.8 (-ve, $\mathrm{CH}_{2}$ ), 66.8 (-ve, $\mathrm{CH}_{2}$ ), 108.8 (+ve, $\mathrm{ArCH}$ ), 109.1 (+ve, $\mathrm{ArCH}$ ), 113.5 (ab, $\mathrm{ArC}), 114.5$ (ab, ArC), 116.5 (+ve, $\mathrm{ArCH}), 116.6$ (+ve, $\mathrm{ArCH}$ ), 117.7 (+ve, $\mathrm{ArCH}$ ), 118.6 (+ve, $\mathrm{ArCH}$ ), 119.8 (+ve, $\mathrm{ArCH}$ ), 121.3 (ab, ArC), 122.2 (+ve, $\mathrm{ArCH}$ ), 122.28 (ab, $\mathrm{ArC}), 122.7$ (+ve, $\mathrm{ArCH}$ ), 122.9 (+ve, $\mathrm{ArCH}$ ), 123.1 (+ve, $\mathrm{ArCH}$ ), 123.8 (ab, ArC), 124.0 (+ve, $\mathrm{ArCH}$ ), 124.6 (+ve, $\mathrm{ArCH}$ ), 125.0 (+ve, $\mathrm{ArCH}$ ), 127.7 (+ve, $\mathrm{ArCH}$ ), 128.8 (+ve, $\mathrm{ArCH}$ ), 128.9 (+ve, $\mathrm{ArCH}$ ), 128.97 (+ve, $\mathrm{ArCH}$ ), 129.0 (+ve, $\mathrm{ArCH}$ ), 129.2 (+ve, $\mathrm{ArCH}$ ), 130.3 (+ve, $\mathrm{ArCH}$ ), 130.4 (ab, $\mathrm{ArC}), 130.6$ (+ve, $\mathrm{ArCH}), 130.8$ (ab, ArC), 131.1 (ab, ArC), $131.3(\mathrm{ab}, \mathrm{ArC})$, 133.9 (+ve, $\mathrm{ArCH}$ ), 135.5 (ab, ArC), 135.6 (ab, ArC), 135.9 (ab, ArC), 136.0 (ab, ArC), 139.7 (ab, ArC), 141.7 (ab, ArC), 162.7 (ab, ArC), 163.0 (ab, ArC), 164.7 (ab, ArC), 164.8 (ab, $\operatorname{ArC}), 165.3(\mathrm{ab}, \operatorname{ArC}), 165.4(\mathrm{C}=\mathrm{O}), 167.5(\mathrm{C}=\mathrm{O})$. HRMS
(ESI): calcd for $\mathrm{C}_{35} \mathrm{H}_{31} \mathrm{~N}_{7} \mathrm{O}_{2} \mathrm{Cl}_{2}\left([\mathrm{M}+\mathrm{H}]^{+}\right), 652.1989$; found, 652.1955.

4.1.5.11. (Z)-3-((1-(4-Morpholino-6-(piperidin-1-yl)-1,3,5triazin-2-yl)-1H-indol-3-yl)methylene)indolin-2-one (10). As per the general procedure, compound 10 was synthesized using 7 and indolin-2-one. Yellow solid, yield 69\%, mp $294-296^{\circ} \mathrm{C}$. IR (KBr): 3001, 2936, 2850, 1697, 1605, 1570, 1447, 1408 $\mathrm{cm}^{-1} \cdot{ }^{1} \mathrm{H}$ NMR $\left(500 \mathrm{MHz}, \mathrm{CDCl}_{3}\right): \delta 1.82\left(\mathrm{~m}, 6 \mathrm{H}, 3 \times \mathrm{CH}_{2}\right)$, 3.93-4.04 (m, 12H, $\left.6 \times \mathrm{CH}_{2}\right), 7.00(\mathrm{t}, 1 \mathrm{H}, J=6.7 \mathrm{~Hz}, \mathrm{ArH})$, 7.09 (d, $1 \mathrm{H}, J=7.81 \mathrm{~Hz}, \operatorname{ArH}), 7.33(\mathrm{t}, 1 \mathrm{H}, J=7.81 \mathrm{~Hz}, \operatorname{ArH})$, 7.46-7.47 (m, 1H, ArH), 7.51-7.53 (m, 1H, ArH), 7.73 (d, $1 \mathrm{H}, J=7.81 \mathrm{~Hz}, \operatorname{ArH}), 7.82(\mathrm{~d}, 1 \mathrm{H}, J=7.81 \mathrm{~Hz}, \operatorname{ArH}), 8.05$ (s, $1 \mathrm{H}$, bridged $\mathrm{H}), 8.45(\mathrm{~d}, 1 \mathrm{H}, J=7.81 \mathrm{~Hz}, \operatorname{ArH}), 8.75(\mathrm{~s}, 1 \mathrm{H}$, $\mathrm{NH}), 9.69$ (s, $1 \mathrm{H}, \mathrm{CH}) .{ }^{13} \mathrm{C} \mathrm{NMR}\left(125 \mathrm{MHz}, \mathrm{CDCl}_{3}\right): \delta 23.4$ (-ve, $\mathrm{CH}_{2}$ ), 25.4 (-ve, $\mathrm{CH}_{2}$ ), 46.0 (-ve, $\mathrm{CH}_{2}$ ), 47.5 (-ve, $\mathrm{CH}_{2}$ ), 65.9 (-ve, $\mathrm{CH}_{2}$ ) 111.2 (ab, $\mathrm{ArC}$ ), 111.5 (+ve, $\mathrm{ArCH}$ ), 113.4 (ab, ArC), 115.7 (ab, ArC), 116.5 (+ve, $\operatorname{ArCH}), 118.0$ (ab, ArC), 120.6 (+ve, $\mathrm{ArCH}$ ), 121.6 (ab, ArC), 123.0 (+ve, $\mathrm{ArCH}$ ), 123.2 (+ve, $\mathrm{ArCH}), 125.0$ (+ve, $\mathrm{ArCH}), 126.3$ (+ve, $\mathrm{ArCH}$ ), 127.8 (+ve, $\mathrm{ArCH}$ ), 129.6 (+ve, $\mathrm{ArCH}), 130.3$ (+ve, $\operatorname{ArCH}$ ), 135.3 (ab, ArC), 140.2 (ab, ArC), 154.9 (ab, ArC), $156.3(\mathrm{C}=\mathrm{O}), 172.2(\mathrm{ab}, \mathrm{ArC})$. HRMS (ESI): calcd for $\mathrm{C}_{29} \mathrm{H}_{29} \mathrm{~N}_{7} \mathrm{O}_{2}\left([\mathrm{M}+\mathrm{H}]^{+}\right)$, 508.2455; found, 508.2434.

4.1.5.12. 1,3-Dimethyl-5-((1-(4-morpholino-6-(piperidin-1yl)-1,3,5-triazin-2-yl)-1H-indol-3-yl)methylene)pyrimidine2,4,6(1,3,5H)-trione (11). Compound 11 was synthesized according to the general procedure given above using 7 and 1,3-dimethyl barbituric acid. Yellow solid, yield $81 \%, \mathrm{mp}>300$ ${ }^{\circ} \mathrm{C}$. IR (KBr): 3193, 2924, 2849, 1662, 1595, 1496, 1450, 1388 $\mathrm{cm}^{-1}$. ${ }^{1} \mathrm{H}$ NMR $\left(500 \mathrm{MHz}, \mathrm{CDCl}_{3}\right): \delta 1.74-1.75(\mathrm{~m}, 6 \mathrm{H}, 3 \times$ $\left.\mathrm{CH}_{2}\right), 3.45\left(\mathrm{~s}, 3 \mathrm{H}, \mathrm{CH}_{3}\right), 3.46\left(\mathrm{~s}, 3 \mathrm{H}, \mathrm{CH}_{3}\right), 3.83-3.97(\mathrm{~m}$, $\left.12 \mathrm{H}, 6 \times \mathrm{CH}_{2}\right), 7.41-7.43(\mathrm{~m}, 2 \mathrm{H}, \mathrm{ArH}), 7.96-7.97(\mathrm{~m}, 1 \mathrm{H}$, ArH), 8.65-8.67 (m, 1H, ArH), 8.99 (s, 1H, bridged $\mathrm{H}), 10.45$ $(\mathrm{s}, 1 \mathrm{H}, \mathrm{CH}) \cdot{ }^{13} \mathrm{C}$ NMR $\left(125 \mathrm{MHz}, \mathrm{CDCl}_{3}\right): \delta 24.7$ (-ve, $\mathrm{CH}_{2}$ ), 25.7 (-ve, $\mathrm{CH}_{2}$ ), 28.1 (+ve, $\mathrm{CH}_{3}$ ), 28.9 (+ve, $\mathrm{CH}_{3}$ ), 43.9 (-ve, $\mathrm{CH}_{2}$ ), 44.5 (-ve, $\mathrm{CH}_{2}$ ), 44.9 (-ve, $\mathrm{CH}_{2}$ ), 66.8 (-ve, $\mathrm{CH}_{2}$ ), 111.9 (ab, ArC), 113.6 (ab, ArC), 116.7 (+ve, $\mathrm{ArCH}), 118.1$ (+ve, $\mathrm{ArCH}$ ), 123.7 (+ve, $\mathrm{ArCH}$ ), 124.8 (+ve, $\mathrm{ArCH}$ ), 131.7 (ab, $\mathrm{ArC}$ ), 135.7 (ab, $\mathrm{ArC}$ ), 139.3 (+ve, $\mathrm{ArCH}$ ), 146.2 (+ve, $\mathrm{ArCH}$ ), 151.7 (ab, $\mathrm{ArC}), 161.5$ (ab, $\mathrm{ArC}), 162.9$ (ab, ArC), $163.4(\mathrm{ab}, \operatorname{ArC}), 164.7(\mathrm{C}=\mathrm{O}), 165.3(\mathrm{C}=\mathrm{O})$. HRMS (ESI): calcd for $\mathrm{C}_{27} \mathrm{H}_{30} \mathrm{~N}_{8} \mathrm{O}_{4}\left([\mathrm{M}+\mathrm{H}]^{+}\right)$, 531.2462; found, 531.2494.

4.1.5.13. (Z)-1-(3-Chlorophenyl)-3-methyl-4-((1-(4-morpholino-6-(piperidin-1-yl)-1,3,5-triazin-2-yl)-1H-indol-3-yl)methylene)-1H-pyrazol-5(4H)-one (12). As per the procedure given above, compound 12 was synthesized using 7 and 1-(3chlorophenyl)-3-methyl-1H-pyrazol-5(4H)-one. Orange solid, yield $75 \%, \mathrm{mp}>300{ }^{\circ} \mathrm{C}$. IR $(\mathrm{KBr}): 3156,2922,2851,1682$, $1592,1570,1500,1445,1401,1288 \mathrm{~cm}^{-1} .{ }^{1} \mathrm{H}$ NMR $(500 \mathrm{MHz}$, $\left.\mathrm{CDCl}_{3}\right): \delta 1.72-1.76\left(\mathrm{~m}, 6 \mathrm{H}, 3 \times \mathrm{CH}_{2}\right), 2.40\left(\mathrm{~s}, 3 \mathrm{H}, \mathrm{CH}_{3}\right)$, $3.86\left(\mathrm{~m}, 12 \mathrm{H}, 6 \times \mathrm{CH}_{2}\right), 7.14(\mathrm{~d}, 1 \mathrm{H}, J=6.82 \mathrm{~Hz}, \mathrm{ArH}), 7.34$ $(\mathrm{t}, 1 \mathrm{H}, J=7.96 \mathrm{~Hz}, \mathrm{ArH}), 7.38-7.42(\mathrm{~m}, 2 \mathrm{H}, \mathrm{ArH}), 7.68(\mathrm{~s}$, $1 \mathrm{H}$, bridged $\mathrm{H}$ ), 7.79 (d, $1 \mathrm{H}, J=6.82 \mathrm{~Hz}, \mathrm{ArH}), 7.94$ (d, $1 \mathrm{H}, J$ $=7.96 \mathrm{~Hz}, \mathrm{ArH}), 8.28(\mathrm{~s}, 1 \mathrm{H}, \mathrm{ArH}), 8.67(\mathrm{~d}, 1 \mathrm{H}, J=7.96 \mathrm{~Hz}$, $\mathrm{ArH}), 10.83$ (s, $1 \mathrm{H}, \mathrm{CH}) .{ }^{13} \mathrm{C} \mathrm{NMR}\left(125 \mathrm{MHz}, \mathrm{CDCl}_{3}\right): \delta$ 13.1 (+ve, $\mathrm{CH}_{3}$ ), 24.8 (-ve, $\mathrm{CH}_{2}$ ), 25.8 (-ve, $\mathrm{CH}_{2}$ ), 43.9 (-ve, $\mathrm{CH}_{2}$ ), 44.7 (-ve, $\mathrm{CH}_{2}$ ), $66.8\left(-\mathrm{ve}, \mathrm{CH}_{2}\right), 113.8(\mathrm{ab}, \mathrm{ArC})$, 116.1 (+ve, $\mathrm{ArCH}$ ), 116.9 (+ve, $\mathrm{ArCH}), 117.6$ (+ve, $\mathrm{ArCH}$ ), 118.4 (+ve, $\mathrm{ArCH}$ ), 122.6 (ab, ArC), 123.3 (+ve, $\mathrm{ArCH}$ ), 123.9 (+ve, $\mathrm{ArCH}$ ), 124.6 (+ve, $\mathrm{ArCH}), 129.6$ (+ve, $\mathrm{ArCH}$ ), 130.5 (ab, ArC), 134.3 (ab, ArC), 134.8 (+ve, $\operatorname{ArCH}), 135.7$ (ab, $\mathrm{ArC}$ ), 138.2 (+ve, $\operatorname{ArCH}$ ), 140.0 (ab, $\operatorname{ArC}$ ), 150.6 (ab, $\mathrm{ArC}$ ), 
162.7 (ab, ArC), $162.9(\mathrm{C}=\mathrm{O}), 164.7$ (ab, $\operatorname{ArC}), 165.2$ (ab, ArC). HRMS (ESI): calcd for $\mathrm{C}_{31} \mathrm{H}_{31} \mathrm{~N}_{8} \mathrm{O}_{2} \mathrm{Cl}\left([\mathrm{M}+\mathrm{H}]^{+}\right)$, 583.2331; found, 583.2308.

4.1.5.14. 1-(4-Morpholino-6-(pyrrolidin-1-yl)-1,3,5-triazin2-yl)-1H-indole-3-carbaldehyde (13). Compound 13 was prepared by the nucleophilic substitution of the chlorine atom of compound 7 ( $1 \mathrm{mmol})$ with pyrrolidine by performing the reaction in $\mathrm{CHCl}_{3}$ at $100{ }^{\circ} \mathrm{C}$ for $0.5 \mathrm{~h}$ under microwave irradiation. After completion of the reaction (TLC), water was added and extracted with $\mathrm{CHCl}_{3}(4 \times 25 \mathrm{~mL})$. The combined organic layers were dried over $\mathrm{Na}_{2} \mathrm{SO}_{4}$ and concentrated in vacuum to procure crude product. The crude product was further purified by washing with ether to obtain pure compound 13. Creamish white solid, yield 71\%, mp 215-216 ${ }^{\circ} \mathrm{C}$. IR (KBr): 3137, 2958, 2863, 1663, 1572, 1510, 1446, 1409 $\mathrm{cm}^{-1} .{ }^{1} \mathrm{H}$ NMR $\left(500 \mathrm{MHz}, \mathrm{CDCl}_{3}\right): \delta 2.01-2.07(\mathrm{~m}, 4 \mathrm{H}, 2 \times$ $\left.\mathrm{CH}_{2}\right), 3.61-3.64\left(\mathrm{~m}, 2 \mathrm{H}, \mathrm{CH}_{2}\right), 3.75-3.93(\mathrm{~m}, 12 \mathrm{H}, 6 \times$ $\left.\mathrm{CH}_{2}\right), 7.36-7.43(\mathrm{~m}, 2 \mathrm{H}, \mathrm{ArH}), 8.34(\mathrm{~d}, 1 \mathrm{H}, J=7.61 \mathrm{~Hz}$, $\mathrm{ArH}$ ), 8.74 (d, $1 \mathrm{H}, J=7.61 \mathrm{~Hz}, \mathrm{ArH}), 8.88(\mathrm{~s}, 1 \mathrm{H}, \mathrm{CH}), 10.15$ (s, $1 \mathrm{H}, \mathrm{CHO}) .{ }^{13} \mathrm{C} \mathrm{NMR}\left(125 \mathrm{MHz}, \mathrm{CDCl}_{3}\right): \delta 25.1$ (-ve, $\mathrm{CH}_{2}$ ), 25.3 (-ve, $\mathrm{CH}_{2}$ ), 43.9 (-ve, $\mathrm{CH}_{2}$ ), 46.3 (-ve, $\mathrm{CH}_{2}$ ), 46.5 (-ve, $\mathrm{CH}_{2}$ ), 66.7 (-ve, $\mathrm{CH}_{2}$ ), 116.6 (+ve, $\left.\mathrm{ArCH}\right), 120.5$ (ab, $\mathrm{ArC}$ ), 121.8 (+ve, $\mathrm{ArCH}$ ), 123.9 (+ve, $\mathrm{ArCH}$ ), 125.1 (+ve, $\mathrm{ArCH}), 127.0$ (ab, ArC), 136.5 (ab, ArC), 136.8 (+ve, $\mathrm{ArCH})$, 162.3 (ab, ArC), 163.5 (ab, ArC), 164.9 (ab, ArC), 185.8 (C= O). HRMS (ESI): calcd for $\mathrm{C}_{20} \mathrm{H}_{22} \mathrm{~N}_{6} \mathrm{O}_{2}\left([\mathrm{M}+\mathrm{H}]^{+}\right)$, 379.1877; found, 379.1890 .

4.1.5.15. (Z)-1-(2,6-Dichlorophenyl)-3-((1-(4-morpholino6-(pyrrolidin-1-yl)-1,3,5-triazin-2-yl)-1H-indol-3-yl)methylene)indolin-2-one (14). Compound 14 was synthesized as inseparable E- and Z-isomers (2:1, $\left.{ }^{1} \mathrm{H} \mathrm{NMR}\right)$ according to the general procedure given above using compound 7 and 1(2,6-dichlorophenyl)indolin-2-one. Yellow solid, yield 72\%, mp 290-292 ${ }^{\circ} \mathrm{C}$. IR (KBr): 3165, 3049, 2961, 2857, 1713, 1607, 1568, 1511, 1446, 1404, $1361 \mathrm{~cm}^{-1} .{ }^{1} \mathrm{H}$ NMR (500 MHz, $\left.\mathrm{CDCl}_{3}\right): \delta 1.99-2.08\left(\mathrm{~m}, 6 \mathrm{H}, 2 \times \mathrm{CH}_{2(\mathrm{maj})}+2 \times \mathrm{CH}_{2(\mathrm{~min})}\right)$, 3.61-3.66 (m, 3H, CH C(maj $\left.)+\mathrm{CH}_{2(\min )}\right), 3.78-3.95(\mathrm{~m}, 15 \mathrm{H}, 5$ $\left.\times \mathrm{CH}_{2(\text { maj })}+5 \times \mathrm{CH}_{2(\text { min })}\right), 6.45-6.49\left(\mathrm{~m}, 2 \mathrm{H}, \mathrm{ArH}_{\text {maj }}+\right.$ $\left.\mathrm{ArH}_{\text {min }}\right), 7.01\left(\mathrm{t}, 1 \mathrm{H}, J=8.05 \mathrm{~Hz}, \mathrm{ArH}_{\text {maj }}\right), 7.15-7.18(\mathrm{~m}, 1 \mathrm{H}$, $\mathrm{ArH}_{\text {min }}$ ), 7.21-7.24 (m, 2H, $\mathrm{ArH}_{\text {maj }}+\mathrm{ArH}_{\text {min }}$ ), 7.35-7.38 (m, $\left.1 \mathrm{H}, \mathrm{ArH}_{\text {maj }}\right), 7.39-7.45\left(\mathrm{~m}, 4 \mathrm{H}, 2 \times \mathrm{ArH}_{\text {maj }}+2 \times \mathrm{ArH}_{\text {min }}\right)$, 7.54-7.57 (m, 4H, $\left.2 \times \mathrm{ArH}_{\text {maj }}+2 \times \mathrm{ArH}_{\text {min }}\right), 7.76(\mathrm{~d}, 1 \mathrm{H}, J=$ $7.3 \mathrm{~Hz}, \mathrm{ArH}_{\text {min }}$ ), 7.82 (d, $1 \mathrm{H}, J=7.82 \mathrm{~Hz}, \mathrm{ArH}_{\text {maj }}$ ), 7.92-7.94 $\left(\mathrm{m}, 1 \mathrm{H}, \mathrm{ArH}_{\text {min }}\right), 8.04\left(\mathrm{~s}, 1 \mathrm{H}\right.$, bridged $\left.\mathrm{H}_{\text {min }}\right), 8.14(\mathrm{~d}, 1 \mathrm{H}, J=$ $\left.7.82 \mathrm{~Hz}, \operatorname{ArH}_{\text {maj }}\right), 8.21\left(\mathrm{~s}, 1 \mathrm{H}\right.$, bridged $\left.\mathrm{H}_{\text {maj }}\right), 8.79-8.81(\mathrm{~m}$, $\left.2 \mathrm{H}, \mathrm{ArH}_{\text {maj }}+\mathrm{ArH}_{\text {min }}\right), 9.13\left(\mathrm{~s}, 1 \mathrm{H}, \mathrm{CH}_{\text {maj }}\right), 10.23(\mathrm{~s}, 1 \mathrm{H}$, $\left.\mathrm{CH}_{\text {min }}\right) .{ }^{13} \mathrm{C}$ NMR $\left(125 \mathrm{MHz}, \mathrm{CDCl}_{3}\right): \delta 25.2\left(-\mathrm{ve}, \mathrm{CH}_{2}\right)$, 25.3 (-ve, $\mathrm{CH}_{2}$ ), 43.9 (-ve, $\mathrm{CH}_{2}$ ), 46.2 (-ve, $\mathrm{CH}_{2}$ ), 46.5 (-ve, $\mathrm{CH}_{2}$ ), 66.8 (-ve, $\mathrm{CH}_{2}$ ), 108.7 (+ve, $\mathrm{ArCH}$ ), 109.1 (+ve, $\mathrm{ArCH}), 113.5$ (ab, ArC), 114.5 (ab, ArC), 116.8 (+ve, ArCH), 117.0 (+ve, $\mathrm{ArCH}$ ), 117.6 (+ve, $\mathrm{ArCH}), 118.6$ (+ve, $\mathrm{ArCH}$ ), 119.7 (+ve, $\mathrm{ArCH}$ ), 121.3 (ab, $\mathrm{ArC}$ ), 122.2 (+ve, $\mathrm{ArCH}), 122.3$ (ab, $\mathrm{ArC}), 122.7$ (+ve, $\mathrm{ArCH}), 122.9$ (+ve, $\mathrm{ArCH}), 123.1$ (+ve, $\mathrm{ArCH}), 123.8$ (ab, $\mathrm{ArC}), 124.0$ (+ve, $\mathrm{ArCH}), 124.6$ (+ve, $\mathrm{ArCH}), 125.1$ (ab, $\mathrm{ArC}), 126.5$ (+ve, $\mathrm{ArCH}), 127.7$ (+ve, $\mathrm{ArCH}$ ), 128.8 (+ve, $\mathrm{ArCH}$ ), 128.9 (+ve, $\mathrm{ArCH}$ ), 129.0 (+ve, $\mathrm{ArCH}), 129.3$ (+ve, $\mathrm{ArCH}), 130.3$ (+ve, $\mathrm{ArCH}), 130.4$ (ab, $\mathrm{ArC}$ ), 130.5 (+ve, $\mathrm{ArCH}$ ), 130.9 (ab, $\mathrm{ArC}$ ), 131.2 (ab, ArC), 131.3 (ab, ArC), 133.8 (+ve, $\mathrm{ArCH}$ ), 135.6 (ab, ArC), 135.7 (ab, ArC), 136.1 (ab, ArC), 139.7 (ab, ArC), 141.8 (ab, ArC), 162.3 (ab, ArC), 162.5 (ab, ArC), 163.6 (ab, ArC), 163.7 (ab, $\mathrm{ArC}), 165.0(\mathrm{ab}, \mathrm{ArC}), 165.2(\mathrm{C}=\mathrm{O}), 167.5(\mathrm{C}=\mathrm{O}) . \mathrm{HRMS}$
(ESI): calcd for $\mathrm{C}_{34} \mathrm{H}_{29} \mathrm{~N}_{7} \mathrm{O}_{2} \mathrm{Cl}_{2}\left([\mathrm{M}+\mathrm{H}]^{+}\right), 638.1832$; found, 638.1864 .

4.1.5.16. (Z)-3-((1-(4-Morpholino-6-(pyrrolidin-1-yl)-1,3,5triazin-2-yl)-1H-indol-3-yl)methylene)indolin-2-one (15). Compound $\mathbf{1 5}$ was synthesized according to the general procedure by using 7 and indolin-2-one. Yellow solid, yield 70\%, mp 260-262 ${ }^{\circ} \mathrm{C}$. IR (KBr): 3054, 2958, 2868, 1692, 1606, 1567, 1447, $1407 \mathrm{~cm}^{-1} .{ }^{1} \mathrm{H}$ NMR (500 MHz, $\left.\mathrm{CDCl}_{3}\right): \delta$ 2.01-2.05 (m, 4H, $\left.2 \times \mathrm{CH}_{2}\right), 3.62-3.65\left(\mathrm{~m}, 2 \mathrm{H}, \mathrm{CH}_{2}\right), 3.77-$ $3.84\left(\mathrm{~m}, 6 \mathrm{H}, 3 \times \mathrm{CH}_{2}\right), 3.94-3.97\left(\mathrm{~m}, 4 \mathrm{H}, 2 \times \mathrm{CH}_{2}\right), 6.90-$ $6.91(\mathrm{~m}, 1 \mathrm{H}, \mathrm{ArH}), 7.09(\mathrm{t}, 1 \mathrm{H}, J=7.86 \mathrm{~Hz}, \mathrm{ArH}), 7.21-7.24$ (m, 2H, ArH), 7.38-7.42 (m, 2H, ArH), 7.65 (d, 1H, J = 8.65 $\mathrm{Hz}, \mathrm{ArH}), 7.82$ (s, 1H, NH), 7.93 (s, 1H, bridged $\mathrm{H}), 8.82$ (d, $1 \mathrm{H}, J=7.35 \mathrm{~Hz}, \mathrm{ArH}), 10.35(\mathrm{~s}, 1 \mathrm{H}, \mathrm{CH}) .{ }^{13} \mathrm{C} \mathrm{NMR}(125$ $\mathrm{MHz}, \mathrm{CDCl}_{3}$ ): $\delta 25.2\left(-\mathrm{ve}, \mathrm{CH}_{2}\right.$ ), $25.4\left(-\mathrm{ve}, \mathrm{CH}_{2}\right.$ ), 43.8 (-ve, $\mathrm{CH}_{2}$ ), 45.0 (-ve, $\mathrm{CH}_{2}$ ), 46.2 (-ve, $\mathrm{CH}_{2}$ ), 46.5 (-ve, $\mathrm{CH}_{2}$ ), 66.8 (-ve, $\mathrm{CH}_{2}$ ), 109.2 (+ve, $\left.\mathrm{ArCH}\right), 113.6(\mathrm{ab}, \mathrm{ArC}), 116.8$ (ab, ArC), 117.0 (+ve, ArH), 117.6 (+ve, ArH), 118.6 (+ve, $\mathrm{ArH}), 121.5$ (+ve, $\mathrm{ArH}$ ), 122.1 (ab, ArC), 122.7 (+ve, $\mathrm{ArH}$ ), 124.1 (+ve, ArH), 125.7 (ab, ArC), 126.0 (+ve, ArH), 127.7 (+ve, ArH), 129.0 (ab, C), 133.6 (+ve, ArH), 135.6 (ab, ArC), 138.6 (ab, ArC), 162.5 (ab, ArC), 163.7 (ab, ArC), 165.0 (C= O), 168.3 (ab, ArC). HRMS (ESI): calcd for $\mathrm{C}_{28} \mathrm{H}_{27} \mathrm{~N}_{7} \mathrm{O}_{2}([\mathrm{M}$ $\left.+\mathrm{H}]^{+}\right)$, 494.2299; found, 494.2309.

4.1.5.17. 1,3-Dimethyl-5-((1-(4-morpholino-6-(pyrrolidin1-yl)-1,3,5-triazin-2-yl)-1H-indol-3-yl)methylene)pyrimidine$2,4,6(1,3,5 \mathrm{H})$-trione (16). As per the procedure given above, compound 16 was procured using 7 and 1,3-dimethyl barbituric acid. Yellow solid, yield $82 \%, \mathrm{mp} 253-254{ }^{\circ} \mathrm{C}$. IR (KBr): 3192 , 2963, 2868, 1663, 1570, 1501, 1448, $1388 \mathrm{~cm}^{-1}$. ${ }^{1} \mathrm{H}$ NMR (500 $\left.\mathrm{MHz}, \mathrm{CDCl}_{3}\right): \delta 2.02-2.09\left(\mathrm{~m}, 4 \mathrm{H}, 2 \times \mathrm{CH}_{2}\right), 3.46(\mathrm{~s}, 3 \mathrm{H}$, $\left.\mathrm{CH}_{3}\right), 3.46\left(\mathrm{~s}, 3 \mathrm{H}, \mathrm{CH}_{3}\right), 3.63-3.65\left(\mathrm{~m}, 2 \mathrm{H}, \mathrm{CH}_{2}\right), 3.79-3.82$ $\left(\mathrm{m}, 6 \mathrm{H}, 3 \times \mathrm{CH}_{2}\right), 3.91-3.96\left(\mathrm{~m}, 4 \mathrm{H}, 2 \times \mathrm{CH}_{2}\right), 7.41-7.43$ (m, 2H, ArH), 7.96-7.97 (m, 1H, ArH), 8.77-8.78 (m, 1H, ArH), 9.00 (s, 1H, bridged $\mathrm{H}), 10.47(\mathrm{~s}, 1 \mathrm{H}, \mathrm{CH}) .{ }^{13} \mathrm{C}$ NMR $\left(125 \mathrm{MHz}_{\mathrm{CDCl}}\right.$ ): $\delta 25.2\left(-\mathrm{ve}, \mathrm{CH}_{2}\right), 25.3\left(-\mathrm{ve}, \mathrm{CH}_{2}\right), 28.1$ (+ve, $\mathrm{CH}_{3}$ ), 28.9 (+ve, $\mathrm{CH}_{3}$ ), 43.8 (-ve, $\mathrm{CH}_{2}$ ), 46.2 (-ve, $\mathrm{CH}_{2}$ ), 46.3 (-ve, $\mathrm{CH}_{2}$ ), 46.5 (-ve, $\left.\mathrm{CH}_{2}\right), 66.8$ (-ve, $\mathrm{CH}_{2}$ ), 111.9 (ab, ArC), 113.6 (ab, ArC), 117.1 (+ve, $\operatorname{ArCH}), 118.1$ (+ve, $\mathrm{ArCH}$ ), 123.7 (+ve, $\mathrm{ArCH}$ ), 124.8 (+ve, $\mathrm{ArCH}$ ), 131.7 (ab, ArC), 135.8 (ab, ArC), 139.1 (+ve, $\operatorname{ArCH}$ ), 146.4 (+ve, $\mathrm{ArCH}), 151.7$ (ab, ArC), $161.5(\mathrm{ab}, \mathrm{ArC}), 162.4$ (ab, ArC), $163.4(\mathrm{ab}, \mathrm{ArC}), 163.5(\mathrm{C}=\mathrm{O}), 164.9(\mathrm{C}=\mathrm{O})$. HRMS (ESI): calcd for $\mathrm{C}_{26} \mathrm{H}_{28} \mathrm{~N}_{8} \mathrm{O}_{4}\left([\mathrm{M}+\mathrm{H}]^{+}\right)$, 517.2306; found, 517.2286.

4.1.5.18. (Z)-1-(3-Chlorophenyl)-3-methyl-4-((1-(4-morpholino-6-(pyrrolidin-1-yl)-1,3,5-triazin-2-yl)-1H-indol-3-yl)methylene)-1H-pyrazol-5(4H)-one (17). In accordance to the general procedure, compound $\mathbf{1 7}$ was synthesized using 7 and 1-(3-chlorophenyl)-3-methyl-1H-pyrazol-5(4H)-one. Orange solid, yield $76 \%$, mp $280-282{ }^{\circ} \mathrm{C}$. IR ( $\mathrm{KBr}$ ): 3151, 2956, 2864, 1682, 1592, 1571, 1525, 1446, $1390 \mathrm{~cm}^{-1} .{ }^{1} \mathrm{H}$ NMR (500 $\left.\mathrm{MHz}, \mathrm{CDCl}_{3}\right): \delta 2.01-2.09\left(\mathrm{~m}, 4 \mathrm{H}, 2 \times \mathrm{CH}_{2}\right), 2.41(\mathrm{~s}, 3 \mathrm{H}$, $\left.\mathrm{CH}_{3}\right), 3.60-3.63\left(\mathrm{~m}, 2 \mathrm{H}, \mathrm{CH}_{2}\right), 3.81-4.06(\mathrm{~m}, 10 \mathrm{H}, 5 \times$ $\mathrm{CH}_{2}$ ), $7.14(\mathrm{~d}, 1 \mathrm{H}, J=8.19 \mathrm{~Hz}, \mathrm{ArH}), 7.34(\mathrm{t}, 1 \mathrm{H}, J=8.19 \mathrm{~Hz}$, ArH), 7.39-7.42 (m, 2H, ArH), 7.70 (s, 1H, bridged $\mathrm{H}$ ), 7.79 (d, $1 \mathrm{H}, J=6.83 \mathrm{~Hz}, \mathrm{ArH}), 7.95$ (d, $1 \mathrm{H}, J=6.83 \mathrm{~Hz}, \operatorname{ArH}), 8.27$ (s, $1 \mathrm{H}, \operatorname{ArH}), 8.78$ (d, $1 \mathrm{H}, J=6.83 \mathrm{~Hz}, \operatorname{ArH}), 10.84(\mathrm{~s}, 1 \mathrm{H}$, $\mathrm{CH}) .{ }^{13} \mathrm{C}$ NMR (125 MHz, $\mathrm{CDCl}_{3}$ ): $\delta 13.2\left(+\mathrm{ve}, \mathrm{CH}_{3}\right), 25.2$ (-ve, $\mathrm{CH}_{2}$ ), 25.3 (-ve, $\mathrm{CH}_{2}$ ), 43.8 (-ve, $\mathrm{CH}_{2}$ ), 46.3 (-ve, $\mathrm{CH}_{2}$ ), 46.5 (-ve, $\mathrm{CH}_{2}$ ), 66.9 (-ve, $\mathrm{CH}_{2}$ ), 113.8 (ab, $\mathrm{ArC}$ ), 116.2 (+ve, $\mathrm{ArCH}$ ), 117.2 (+ve, $\mathrm{ArCH}), 117.5$ (+ve, $\mathrm{ArCH}$ ), 118.5 (+ve, $\mathrm{ArCH}$ ), 122.6 (ab, ArC), 123.3 (+ve, $\mathrm{ArCH}$ ), 123.9 (+ve, $\mathrm{ArCH}$ ), 124.6 (+ve, $\mathrm{ArCH}$ ), 129.5 (+ve, $\mathrm{ArCH}$ ), 130.5 
(ab, ArC), 134.3 (ab, ArC), 134.8 (+ve, $\mathrm{ArCH}$ ), 135.8 (ab, ArC), 138.0 (+ve, $\mathrm{ArCH}$ ), 140.0 (ab, ArC), 150.6 (ab, ArC), 162.3 (ab, ArC), $163.0(\mathrm{C}=\mathrm{O}), 163.6$ (ab, ArC), $164.8(\mathrm{ab}$, ArC). HRMS (ESI): calcd for $\mathrm{C}_{30} \mathrm{H}_{29} \mathrm{~N}_{8} \mathrm{O}_{2} \mathrm{Cl}\left([\mathrm{M}+\mathrm{H}]^{+}\right)$, 569.2174; found, 569.2145.

4.1.5.19. (Z)-4-((1-(4-Chloro-6-morpholino-1,3,5-triazin-2yl)-1H-indol-3-yl)methylene)-1-(3-chlorophenyl)-3-methyl$1 \mathrm{H}$-pyrazol-5(4H)-one (18). As per the general procedure, compound 18 was synthesized using 7 and 1-(3-chlorophenyl)3-methyl-1H-pyrazol-5(4H)-one. Orange solid, yield 77\%, mp 225-227 ${ }^{\circ} \mathrm{C}$. IR (KBr): 3152, 2960, 2917, 2858, 1678, 1594, 1572, 1494, 1448, $1389 \mathrm{~cm}^{-1} .{ }^{1} \mathrm{H}$ NMR $\left(500 \mathrm{MHz}, \mathrm{CDCl}_{3}\right): \delta$ $2.35\left(\mathrm{~s}, 3 \mathrm{H}, \mathrm{CH}_{3}\right), 3.79-3.81\left(\mathrm{~m}, 2 \mathrm{H}, \mathrm{CH}_{2}\right), 3.89-3.91(\mathrm{~m}$, $\left.4 \mathrm{H}, 2 \times \mathrm{CH}_{2}\right), 3.92-4.05\left(\mathrm{~m}, 2 \mathrm{H}, \mathrm{CH}_{2}\right), 7.16(\mathrm{~d}, 1 \mathrm{H}, \mathrm{J}=8.18$ $\mathrm{Hz}, \mathrm{ArH}), 7.33-7.42(\mathrm{~m}, 3 \mathrm{H}, \mathrm{ArH}), 7.47$ (s, 1H, bridged $\mathrm{H})$, 7.66 (d, $1 \mathrm{H}, J=7 \mathrm{~Hz}, \operatorname{ArH}), 7.92-7.93(\mathrm{~m}, 1 \mathrm{H}, \operatorname{ArH}), 8.20$ (s, $1 \mathrm{H}, \operatorname{ArH}), 8.64$ (d, $1 \mathrm{H}, J=8.18 \mathrm{~Hz}, \operatorname{ArH}), 10.51$ (s, $1 \mathrm{H}, \mathrm{CH})$. ${ }^{13} \mathrm{C}$ NMR (125 MHz, $\mathrm{CDCl}_{3}$ ): $\delta 13.0$ (+ve, $\mathrm{CH}_{3}$ ), 44.2 (-ve, $\mathrm{CH}_{2}$ ), 44.5 (-ve, $\mathrm{CH}_{2}$ ), 66.4 (-ve, $\mathrm{CH}_{2}$ ), 66.5 (-ve, $\mathrm{CH}_{2}$ ), 115.2 (ab, ArC), 116.2 (+ve, $\mathrm{ArCH}), 117.3$ (+ve, $\mathrm{ArCH}), 117.7$ (+ve, $\mathrm{ArCH}$ ), 118.4 (+ve, $\mathrm{ArCH}), 124.1$ (+ve, $\mathrm{ArCH}), 124.2$ (+ve, $\mathrm{ArCH}$ ), 125.3 (+ve, $\mathrm{ArCH}$ ), 126.8 (ab, ArC), 129.7 (+ve, $\mathrm{ArCH}), 130.1$ (ab, ArC), 130.4 (ab, ArC), 133.5 (+ve, $\mathrm{ArCH}$ ), 134.4 (ab, ArC), 135.3 (ab, $\operatorname{ArC}), 136.2$ (+ve, $\operatorname{ArCH}), 139.7$ (ab, ArC), 150.4 (ab, ArC), 162.5 (ab, ArC), $164.2(\mathrm{C}=\mathrm{O})$, 170.7 (ab, ArC). HRMS (ESI): calcd for $\mathrm{C}_{26} \mathrm{H}_{21} \mathrm{~N}_{7} \mathrm{O}_{2} \mathrm{Cl}_{2}([\mathrm{M}+$ $\left.\mathrm{H}]^{+}\right)$, 534.1206; found, 534.1184.

4.1.5.20. 5-((1-(4-Chloro-6-morpholino-1,3,5-triazin-2-yl)$1 \mathrm{H}$-indol-3-yl)methylene)-1,3-dimethylpyrimidine-2,4,6(1,3,5H)-trione (19). Compound 19 was synthesized using 7 and 1,3-dimethyl barbituric acid. Yellow solid, yield 75\%, mp 268-270 ${ }^{\circ} \mathrm{C}$. IR (KBr): 3186, 2962, 2851, 1726, 1669, 1577, $1499,1300 \mathrm{~cm}^{-1} .{ }^{1} \mathrm{H}$ NMR $\left(500 \mathrm{MHz}, \mathrm{CDCl}_{3}\right): \delta 3.46(\mathrm{~s}, 6 \mathrm{H}$, $\left.2 \times \mathrm{CH}_{3}\right), 3.84\left(\mathrm{t}, 2 \mathrm{H}, J=4.95 \mathrm{~Hz}, \mathrm{CH}_{2}\right), 3.90(\mathrm{t}, 2 \mathrm{H}, J=4.71$ $\left.\mathrm{Hz}, \mathrm{CH}_{2}\right), 4.00\left(\mathrm{t}, 2 \mathrm{H}, J=4.95 \mathrm{~Hz}, \mathrm{CH}_{2}\right), 4.06(\mathrm{t}, 2 \mathrm{H}, J=4.95$ $\left.\mathrm{Hz}, \mathrm{CH}_{2}\right), 7.45-7.47$ (m, 2H, ArH), 7.93-7.95 (m, 1H, ArH), 8.65-8.67 (m, 1H, ArH), $8.91(\mathrm{~s}, 1 \mathrm{H}$, bridged $\mathrm{H}), 10.28(\mathrm{~s}$, $1 \mathrm{H}, \mathrm{CH}) .{ }^{13} \mathrm{C} \mathrm{NMR}\left(125 \mathrm{MHz}, \mathrm{CDCl}_{3}\right): \delta 28.3\left(+\mathrm{ve}, \mathrm{CH}_{3}\right)$, 28.9 (+ve, $\mathrm{CH}_{3}$ ), 44.4 (-ve, $\left.\mathrm{CH}_{2}\right), 44.6$ (-ve, $\mathrm{CH}_{2}$ ), 66.4 (-ve, $\mathrm{CH}_{2}$ ), 66.5 (-ve, $\mathrm{CH}_{2}$ ), 113.9 (ab, $\left.\mathrm{ArC}\right), 115.0(\mathrm{ab}, \mathrm{ArC})$, 117.0 (+ve, $\mathrm{ArCH}$ ), 118.4 (+ve, $\mathrm{ArCH}), 124.5$ (+ve, $\mathrm{ArCH}$ ), 125.6 (+ve, $\mathrm{ArCH}$ ), 131.7 (ab, ArC), 135.3 (ab, ArC), 137.4 (+ve, $\operatorname{ArCH}$ ), 145.4 (+ve, $\operatorname{ArCH}$ ), 151.4 (ab, $\operatorname{ArC}$ ), 161.3 (ab, ArC), 162.8 (ab, ArC), $163.0(\mathrm{C}=\mathrm{O}), 164.5(\mathrm{C}=\mathrm{O}), 170.8$ (ab, ArC). HRMS (ESI): calcd for $\mathrm{C}_{22} \mathrm{H}_{20} \mathrm{~N}_{7} \mathrm{O}_{4} \mathrm{Cl}\left([\mathrm{M}+\mathrm{H}]^{+}\right)$, 482.1338; found, 482.1365 .

4.1.5.21. (Z)-3-((1-(4-Chloro-6-morpholino-1,3,5-triazin-2yl)-1H-indol-3-yl)methylene)indolin-2-one (20). Compound 20 was synthesized using 7 and indolin-2-one. Yellow solid, yield $68 \%$, mp $294-296{ }^{\circ} \mathrm{C}$. IR ( $\left.\mathrm{KBr}\right): 3160,3072$, 2862, 1696, 1608, 1565, 1502, $1451 \mathrm{~cm}^{-1} .{ }^{1} \mathrm{H}$ NMR $\left(500 \mathrm{MHz} \mathrm{CDCl}_{3}\right): \delta$ $3.73-3.96\left(\mathrm{~m}, 8 \mathrm{H}, 4 \times \mathrm{CH}_{2}\right), 6.87(\mathrm{~d}, 1 \mathrm{H}, J=7.78 \mathrm{~Hz}, \mathrm{ArH})$, $7.03(\mathrm{t}, 1 \mathrm{H}, J=7.75 \mathrm{~Hz}, \mathrm{ArH}), 7.23(\mathrm{t}, 1 \mathrm{H}, J=6.45 \mathrm{~Hz}, \mathrm{ArH})$, 7.44-7.48 (m, 2H, ArH), 7.97-7.99 (m, 1H, ArH), 8.06-8.08 (m, 1H, ArH), 8.28-8.31 (m, 1H, ArH), 8.60 (s, 1H, bridged $\mathrm{H}), 10.20(\mathrm{~s}, 1 \mathrm{H}, \mathrm{CH}), 10.69$ (s, 1H, NH). ${ }^{13} \mathrm{C}$ NMR $(125$ $\mathrm{MHz}, \mathrm{CDCl}_{3}$ ): $\delta 44.5\left(-\mathrm{ve}, \mathrm{CH}_{2}\right), 44.7\left(-\mathrm{ve}, \mathrm{CH}_{2}\right), 66.0$ (-ve, $\mathrm{CH}_{2}$ ), 66.1 (-ve, $\mathrm{CH}_{2}$ ), 109.8 (+ve, $\mathrm{ArCH}$ ), 115.7 (ab, $\mathrm{ArC}$ ), 117.0 (+ve, ArH), 119.7 (+ve, ArH), 120.4 (+ve, ArH), 121.3 (+ve, ArH), 124.3 (+ve, ArH), 125.1 (ab, ArC), 125.5 (+ve, ArH), 125.6 (+ve, ArH), 129.0 (+ve, $\operatorname{ArH}), 131.5$ (ab, C), 131.6 (+ve, ArH), 134.9 (ab, ArC), 140.7 (ab, ArC), 162.5 (ab, $\operatorname{ArC}), 164.5$ ( $\mathrm{C}=\mathrm{O}), 168.1$ ( $\mathrm{ab}, \operatorname{ArC}), 169.8$ (ab, ArC). HRMS
(ESI): calcd for $\mathrm{C}_{24} \mathrm{H}_{19} \mathrm{~N}_{6} \mathrm{O}_{2} \mathrm{Cl}\left([\mathrm{M}+\mathrm{H}]^{+}\right), 459.1330$; found, 459.1293.

4.1.5.22. 1-(4,6-Di(piperidin-1-yl)-1,3,5-triazin-2-yl)-1H-indole-3-carbaldehyde (21). $\mathrm{NaH}$ (1.2 mmol) was washed 3-4 times with dry hexane and then suspended in dry ACN (20 $\mathrm{mL}$ ). To the $\mathrm{NaH}$ suspension in dry $\mathrm{ACN}, 1 \mathrm{mmol}$ indole-3carboxaldehyde was added and stirred at $0{ }^{\circ} \mathrm{C}$ for 5-10 min. Then, compound $23(1.2 \mathrm{mmol})$ was added, and the reaction mixture was stirred continuously. On completion of the reaction (TLC), ice cold water was added and washed with ethyl acetate $(4 \times 25 \mathrm{~mL})$. The combined organic layers were dried over anhydrous $\mathrm{Na}_{2} \mathrm{SO}_{4}$ and concentrated in vacuum. The residue was column-chromatographed by using ethyl acetate-hexane as eluents to procure product 21. Creamish white solid, yield $62 \%, \mathrm{mp} 210-212{ }^{\circ} \mathrm{C}$. IR ( $\left.\mathrm{KBr}\right): 3130,3000$, 2928, 2851, 2209, 1584, 1513, 1446, 1406, $1287 \mathrm{~cm}^{-1} .{ }^{1} \mathrm{H}$ $\operatorname{NMR}\left(500 \mathrm{MHz}, \mathrm{CDCl}_{3}\right): \delta 1.67-1.74\left(\mathrm{~m}, 12 \mathrm{H}, 6 \times \mathrm{CH}_{2}\right)$, $3.88\left(\mathrm{~m}, 8 \mathrm{H}, 4 \times \mathrm{CH}_{2}\right), 7.35-7.42(\mathrm{~m}, 2 \mathrm{H}, \mathrm{ArH}), 8.34(\mathrm{~d}, 1 \mathrm{H}$, $J=7.5 \mathrm{~Hz}, \mathrm{ArH}), 8.68$ (d, $1 \mathrm{H}, J=8.4 \mathrm{~Hz}, \mathrm{ArH}), 8.89$ (s, 1H, $\mathrm{CH}), 10.16$ (s, 1H, CHO). ${ }^{13} \mathrm{C}$ NMR $\left(125 \mathrm{MHz} \mathrm{CDCl}_{3}\right): \delta$ 24.8 (-ve, $\mathrm{CH}_{2}$ ), 25.8 (-ve, $\mathrm{CH}_{2}$ ), 44.5 (-ve, $\mathrm{CH}_{2}$ ), 116.4 (+ve, $\mathrm{ArCH}$ ), 120.3 (+ve, $\mathrm{ArCH}$ ), 121.8 (+ve, $\mathrm{ArCH}$ ), 123.8 (+ve, $\mathrm{ArCH}$ ), 125.0 (+ve, $\mathrm{ArCH}$ ), 126.9 (ab, ArC), 136.4 (ab, $\mathrm{ArC}$ ), 137.2 (+ve, $\operatorname{ArCH}$ ), 162.7 (ab, $\operatorname{ArC}$ ), 164.8 (ab, $\mathrm{ArC}$ ), $185.9(\mathrm{C}=\mathrm{O})$. HRMS (ESI): calcd for $\mathrm{C}_{22} \mathrm{H}_{26} \mathrm{~N}_{6} \mathrm{O}([\mathrm{M}+$ $\mathrm{H}]^{+}$), 391.2240; found, 391.2262.

4.1.5.23. (Z)-1-(3-Chlorophenyl)-4-((1-(4,6-di(piperidin-1yl)-1,3,5-triazin-2-yl)-1H-indol-3-yl)methylene)-3-methyl-1Hpyrazol-5(4H)-one (22). Compound 22 was prepared through Knoevenagel condensation of compound 21 (1 mmol) with 1(3-chlorophenyl)-3-methyl-2-pyrazolin-5-one $(1 \mathrm{mmol})$ in the presence of piperidine in $\mathrm{CHCl}_{3}$ at $100{ }^{\circ} \mathrm{C}$ for $2 \mathrm{~h}$ under microwave irradiation. After completion of the reaction (TLC), water was added to the reaction mixture and extracted with $\mathrm{CHCl}_{3}(4 \times 25 \mathrm{~mL})$. The combined organic layers were dried over $\mathrm{Na}_{2} \mathrm{SO}_{4}$ and concentrated in vacuum to procure crude product that was further purified by recrystallization from chloroform/methanol $(2: 8)$ to obtain pure compound 22 . Orange solid, yield $71 \%$, mp $270-272{ }^{\circ} \mathrm{C}$. IR (KBr): 2934, 2850, 2209, 1688, 1592, 1571, 1499, 1445, 1404, $1286 \mathrm{~cm}^{-1} .{ }^{1} \mathrm{H}$ $\mathrm{NMR}\left(500 \mathrm{MHz}, \mathrm{CDCl}_{3}\right): \delta 1.79\left(\mathrm{~s}, 12 \mathrm{H}, 6 \times \mathrm{CH}_{2}\right), 2.54(\mathrm{~s}$, $\left.3 \mathrm{H}, \mathrm{CH}_{3}\right), 3.94\left(\mathrm{~s}, 8 \mathrm{H}, 4 \times \mathrm{CH}_{2}\right), 7.20-7.21(\mathrm{~m}, 1 \mathrm{H}, \mathrm{ArH})$, 7.31-7.41 (m, 2H, ArH), 7.48-7.55 (m, 2H, ArH), 7.75-7.77 (m, 1H, ArH), 7.84-7.91 (m, 1H, ArH), 8.02-8.06 (m, 1H, bridged $\mathrm{H}), 8.45-8.46(\mathrm{~m}, 1 \mathrm{H}, \mathrm{ArH}), 10.50(\mathrm{~s}, 1 \mathrm{H}, \mathrm{CH}) .{ }^{13} \mathrm{C}$ NMR $\left(125 \mathrm{MHz}, \mathrm{CDCl}_{3}\right): \delta 12.5$ (+ve, $\left.\mathrm{CH}_{3}\right), 23.4$ (-ve, $\mathrm{CH}_{2}$ ), 25.3 (-ve, $\mathrm{CH}_{2}$ ), 47.5 (-ve, $\mathrm{CH}_{2}$ ), 111.0 (ab, $\mathrm{ArC}$ ), 113.2 (ab, ArC), 115.5 (ab, ArC), 116.2 (ab, ArC), 116.7 (+ve, $\mathrm{ArCH}), 117.7$ (ab, ArC), 118.3 (+ve, $\mathrm{ArCH}), 119.9$ (+ve, $\mathrm{ArCH}$ ), 122.2 (+ve, $\mathrm{ArCH}$ ), 125.2 (+ve, $\mathrm{ArCH}), 126.2$ (+ve, $\mathrm{ArCH}), 127.2$ (ab, ArC), 130.0 (+ve, $\mathrm{ArCH}$ ), 130.2 (+ve, $\mathrm{ArCH}), 130.5$ (ab, ArC), 134.6 (ab, ArC), 135.4 (ab, ArC), 137.7 (+ve, $\mathrm{ArCH}$ ), 138.3 (+ve, $\mathrm{ArCH}$ ), 154.7 (ab, $\mathrm{ArC}), 162.7$ $(\mathrm{C}=\mathrm{O})$. HRMS (ESI): calcd for $\mathrm{C}_{32} \mathrm{H}_{33} \mathrm{~N}_{8} \mathrm{OCl}\left([\mathrm{M}+\mathrm{H}]^{+}\right)$, 581.2538; found, 581.2509.

4.1.5.24. 2-Chloro-4,6-di(piperidin-1-yl)-1,3,5-triazine (23). Piperidine $(0.92 \mathrm{~g}, 10.86 \mathrm{mmol})$ was added dropwise to the stirred solution of cyanuric chloride $(1 \mathrm{~g}, 5.43 \mathrm{mmol})$ in acetone $(40 \mathrm{~mL})$ at $0{ }^{\circ} \mathrm{C}$, followed by the addition of triethylamine $(1.09 \mathrm{~g}, 10.86 \mathrm{mmol})$. Then, the reaction mass was stirred at $\mathrm{rt}$ for $1 \mathrm{~h}$. The reaction was quenched with water and washed with ethyl acetate $(4 \times 25 \mathrm{~mL})$. The combined organic layers were dried over $\mathrm{Na}_{2} \mathrm{SO}_{4}$ and concentrated under 
vacuum to procure crude product. The crude product was further purified by washing with diethyl ether to obtain pure compound 23 . White solid, yield $62 \%, \mathrm{mp} 95-96{ }^{\circ} \mathrm{C}$. ${ }^{1} \mathrm{H}$ NMR $\left(500 \mathrm{MHz}, \mathrm{CDCl}_{3}\right): \delta 1.58-1.59\left(\mathrm{~m}, 8 \mathrm{H}, 4 \times \mathrm{CH}_{2}\right), 1.65-1.66$ $\left(\mathrm{m}, 8 \mathrm{H}, 4 \times \mathrm{CH}_{2}\right), 3.73\left(\mathrm{t}, 8 \mathrm{H}, \mathrm{J}=5.28 \mathrm{~Hz}, 4 \times \mathrm{CH}_{2}\right) \cdot{ }^{13} \mathrm{C}$ NMR $\left(125 \mathrm{MHz}, \mathrm{CDCl}_{3}\right.$ ): $\delta 24.6$ (-ve, $\mathrm{CH}_{2}$ ), 25.7 (-ve, $\mathrm{CH}_{2}$ ), 44.4 (-ve, $\mathrm{CH}_{2}$ ), 164.2 (ab, $\mathrm{ArC}$ ), 169.5 (ab, ArC). HRMS (MS, ESI): calcd for $\mathrm{C}_{13} \mathrm{H}_{20} \mathrm{~N}_{5} \mathrm{Cl}\left([\mathrm{M}+\mathrm{H}]^{+}\right)$, 282.1480; found, 282.1508 .

4.1.6. Synthesis of Compound 24. $\mathrm{NaH}(1.2 \mathrm{mmol})$ was washed with dry hexane and suspended in dry ACN $(20 \mathrm{~mL})$ to which indole-3-carboxaldehyde $(1 \mathrm{mmol})$ was added at $0{ }^{\circ} \mathrm{C}$. After stirring for 5-10 min, 1,3,5-triazine (1 mmol) was added to the reaction mixture. On completion of the reaction (TLC), ice cold water was added. The solid product was separated, which was filtered and dried under vacuum to procure pure product 24 . White solid, yield $45 \%, \mathrm{mp}>300{ }^{\circ} \mathrm{C}$. ${ }^{1} \mathrm{H}$ NMR $\left(500 \mathrm{MHz}, \mathrm{CDCl}_{3}+\mathrm{TFA}\right): \delta 7.58-7.61(\mathrm{~m}, 3 \mathrm{H}, \mathrm{ArH}), 7.65-$ $7.68(\mathrm{~m}, 3 \mathrm{H}, \mathrm{ArH}), 8.39$ (d, 3H, J = $7.66 \mathrm{~Hz}, \operatorname{ArH}), 8.76$ (d, $3 \mathrm{H}, J=8.39 \mathrm{~Hz}, \mathrm{ArH}), 9.11$ (s, 3H, ArH), 10.16 (s, 3H, CHO). ${ }^{13} \mathrm{C}$ NMR (125 MHz, $\left.\mathrm{CDCl}_{3}+\mathrm{TFA}\right): \delta 110.8$ (ab, C), 113.0 (ab, C), 115.3 (ab, C), 116.2 (+ve, ArCH), 117.6 (ab, C), 122.3 (ab, C), 122.9 (+ve, ArCH), 126.5 (ab, C), 126.5 (+ve, ArCH), 127.3 (+ve, $\operatorname{ArCH}$ ), 136.0 (ab, C), 138.4 (+ve, $\mathrm{ArCH}$ ), 189.9 $(\mathrm{C}=\mathrm{O})$. HRMS (APCI): calcd for $\mathrm{C}_{30} \mathrm{H}_{18} \mathrm{~N}_{6} \mathrm{O}_{3}\left([\mathrm{M}+\mathrm{H}]^{+}\right)$, 511.1513; found, 511.1521.

4.2. Docking Procedure. Schrodinger software package was used for performing the molecular docking of the compounds in the COX-2 (PDB ID 1CVU) and COX-1 (PDB ID 1DIY) active site by following the procedure reported in the previous paper. ${ }^{20}$

4.2.1. Field-Based 3D-QSAR Model. Field-based QSAR tool of Schrodinger 2015-4 was used for the 3D-QSAR analysis by following the reported procedure. ${ }^{20}$

4.3. Procedure for MD Simulation. The docked complex of compound 6 with COX-2 was optimized using MD simulation on DESMOND module in the Schrodinger Maestro 10.1 version with OPLS-2005 force field in explicit solvent with the TIP3P water model. The docked complex was placed in TIP3P water molecules adequately, the dimensions of each orthorhombic water box were $10 \AA \times 10 \AA \times 10 \AA$, and the systems were neutralized by adding $\mathrm{Na}^{+}$counterions to balance the net charges of the systems, and then $0.15 \mathrm{M} \mathrm{NaCl}$ was added. The generated solvent model for the docked complex contained about 59176 atoms. Before MD simulations, the systems were minimized and pre-equilibrated using the default relaxation protocol executed in DESMOND. NVT MD simulations were performed at $10 \mathrm{~K}$ for $100 \mathrm{ps}$ with restraints on heavy atoms. Then, the system was simulated for another 12 ps at $10 \mathrm{~K}$ with the same settings. This was followed by NPT equilibration at $10 \mathrm{~K}$ for $12 \mathrm{ps}$. Then, the system was simulated for $12 \mathrm{ps}$ at $300 \mathrm{~K}$ with restraints on heavy atoms. Finally, restraints on heavy atoms were removed, and the system was simulated for 24 ps at $300 \mathrm{~K}$ with a thermostat relaxation time of $1 \mathrm{ps}$ and a barostat relaxation time of 2 ps. After minimization and equilibration, $\mathrm{MD}$ simulations were performed at $300 \mathrm{~K}$ for $50 \mathrm{~ns}$ with the Martyna-Tobias-Klein method. Data were collected every 1.5 ps during the MD runs.

4.4. Procedure for COX-1 and COX-2 Enzyme Immunoassay. COX-1/2 inhibitory immunoassays were performed by following the already reported procedure. ${ }^{20}$
4.5. Human Whole Blood Assay. The human whole blood assay was performed by using the procedure given in the previous report. $^{20}$

4.6. Analgesic and Anti-Inflammatory Activity. Prior permission was sought from the Institutional Animal Ethical Committee of Guru Nanak Dev University, Amritsar, for using animals. The analgesic and anti-inflammatory activity of the compounds was determined by using male/female Swiss albino mice weighing $25-35 \mathrm{~g}$. The animals were given free supply of food and water and kept at $22 \pm 2{ }^{\circ} \mathrm{C}$ under $12 \mathrm{~h}$ light/dark cycle. A total of 12 groups of animals with five animals in each group and a previously described ${ }^{15 b, 19}$ procedure were used for screening the analgesic and anti-inflammatory activity of the compounds.

4.6.1. Mechanistic Studies. Three groups of mice, five in each group, were used to explore the mode of working of the compound. $^{20}$ Substance P, L-arginine, and NOS inhibitor, LNAME pretreatment, were given $30 \mathrm{~min}$ before administering compound 6.

4.6.2. Acute Toxicity Studies. Acute toxicity studies were performed with four groups of animals, three animals in each group. After $4 \mathrm{~h}$ of fasting, the first group of animals was given vehicle and served as the control group; the second, third, and the fourth groups were given compound 6 at doses of 50, 300, and $2000 \mathrm{mg} \mathrm{kg}^{-1}$, respectively. During the first $4 \mathrm{~h}$, the animals were observed continuously and periodically during the next 24 h. After 14 days, one animal each from the first and third group was sacrificed, and the histological studies were performed using $\mathrm{H}$ and $\mathrm{E}$ staining.

4.7. In Vivo Pharmacokinetic Studies. The in vivo pharmacokinetic properties were performed by using a male Wistar rat $(250-300 \mathrm{~g})$. A dose of $10 \mathrm{mg} \mathrm{kg}^{-1}$ of $0.1 \%$ CMC suspension of the compound was administered i.p. to the rats. The animals were anesthetized with ketamine $\left(50 \mathrm{mg} \mathrm{kg}^{-1}\right.$ i.p. $)$. The blood samples from the jugular vein were withdrawn in heparinized tubes at an interval of 30 and $60 \mathrm{~min}$ and 2, 3, 4, 6, 8,11 , and 24 h of compound administration. The samples were centrifuged at $8000 \mathrm{rpm}$ for $10 \mathrm{~min}$ at $-4{ }^{\circ} \mathrm{C}$, and the clear serum was separated and stored at $-20{ }^{\circ} \mathrm{C}$ until analyzed. The concentration of compound in the serum was determined using LC-MS after preparing the samples by the protein precipitation method. Plasma sample $(100 \mu \mathrm{L})$ was taken in $1.5 \mathrm{~mL}$ tube and vortexed for $3 \mathrm{~min}$. ACN $(300 \mu \mathrm{L})$ with internal standard was added to the above tube and vortexed for $5 \mathrm{~min}$. The tube was centrifuged at $4{ }^{\circ} \mathrm{C}, 16000 \mathrm{rpm}$ for 40 min. The compound with initial concentration $3 \mathrm{mg} \mathrm{mL}^{-1}$ followed by serial dilution was used for obtaining the standard curve. LC-MS was performed with a Dionex ultimate 3000 HPLC system attached to a Bruker MicroTof QII mass spectrometer. A $50 \mathrm{~mm}, 5 \mu \mathrm{m}$ PRP C18 column was used for high-performance liquid chromatography (HPLC), and the gradient mobile phase consisted of water and acetonitrile (each containing $0.1 \%$ formic acid). The initial composition was $20 \%$ acetonitrile and linearly increased to $100 \%$ in $30 \mathrm{~min}$. The column eluent was introduced to the ESI source of mass spectrometer operating in +ve mode. The different pharmacokinetic parameters such as $t_{1 / 2}(\mathrm{~min})$, area under curve (AUC), $C_{\max }(\mu \mathrm{g} / \mathrm{mL}), t_{\max }(\min )$, mean residence time $(\min )$, and clearance $(\mathrm{Cl})(\mathrm{mg}) /(\mu \mathrm{g} / \mathrm{mL}) / \mathrm{min}$ were determined following noncompartmental analysis in PK solver software. ${ }^{26}$

4.8. NMR Studies for Protein-Ligand Interactions. NMR experiments were performed on a Bruker AVANCE 500 NMR spectrometer at $298.2 \mathrm{~K}$. The diffusion measurements 
were carried out using "ledbpgppr2s" pulse program. The gradient pulse length (P30) and the diffusion time (D20) were kept fixed after optimizing the parameters. The values for $\delta$ and $\Delta$ are 1.5 and $50 \mathrm{~ms}$, respectively. A longitudinal eddy current delay (D21) of $5 \mathrm{~ms}$ was used. The sample temperature was kept constant at $298 \pm 0.1 \mathrm{~K}$.

The pseudo-2D data were processed. The diffusion coefficients were obtained with the help of the $T_{1} / T_{2}$ relaxation module of Topspin as described in the diffusion manual of this software, whereas the fitting-type "intensity" was used.

4.8.1. ${ }^{1} \mathrm{H} N \mathrm{NMR} T_{1}$ Relaxation Time Measurements. ${ }^{1} \mathrm{H}$ NMR $T_{1}$ relaxation time measurements were performed on a Bruker AVANCE 500 NMR spectrometer at $298.2 \mathrm{~K}$. The longitudinal relaxation time $\left(T_{1}\right)$ was determined by $180^{\circ}-90^{\circ}$ inversion recovery pulse sequence. Sixteen values of delay time $(\tau)$ were applied, and 16 scans for each $\tau$ value were recorded. The preacquisition delay $(D 1)$ was set to $2 \times T_{1}(5 \mathrm{~s})$ of the longest relaxation time. The value of the longitudinal relaxation time was obtained with the help of $T_{1} / T_{2}$ relaxation module of Topspin as described in the manual of this software, whereas the fitting function "invec" and fitting type "area" were used.

4.9. UV-Visible Spectral Studies. Enzyme ( $3 \mu \mathrm{L})$ was diluted to $100 \mu \mathrm{L}$ in Tris-HCl buffer, and $10 \mu \mathrm{M}$ solution of the compound was prepared in HPLC-grade DMSO and Tris- $\mathrm{HCl}$ buffer (1:9) $(\mathrm{pH} 7.4)$. Incremental addition of the enzyme solution to the compound solution $(10 \mu \mathrm{M})$ was made, and spectra were recorded.

4.10. ITC Experiments. Solution $(50 \mu \mathrm{M})$ of compound 6 in HPLC-grade ethanol and phosphate buffer (1:99) ( $\mathrm{pH} 7.4)$ was prepared. Enzyme $(10 \mu \mathrm{L})$ was diluted in $1 \mathrm{~mL}$ of phosphate buffer. The enzyme solution was taken in the sample cell to which 19 additions of compound 6 , each of $2 \mu \mathrm{L}$, were made at equal intervals of $120 \mathrm{~s}$. The experiments were performed in triplicate, and the difference between the values was $<1 \%$. The control experiments were performed with the same titrant (solution of compound 6) with buffer in the cell. Also, the successive buffer additions to the enzyme solution were carried out. The background heat of the control experiments was subtracted from the main experiment. To eliminate heat of mixing and heat of dilution, the total heat change $Q$ involved in the cell volume $V_{\mathrm{o}}$ at fractional saturation $Q$ after the $i$ th injection was determined. The binding parameters were read with origin 7.0 software of MicroCal, and a single binding site model was used to fit the data.

\section{ASSOCIATED CONTENT}

\section{S Supporting Information}

The Supporting Information is available free of charge on the ACS Publications website at DOI: 10.1021/acsomega.8b00445.

${ }^{1} \mathrm{H}$ and ${ }^{13} \mathrm{C}$ NMR spectra, mass spectra, IR spectra, QSAR data, and molecular docking data (PDF)

IC data of indole-triazines against COX-1 and COX-2 (CSV)

\section{AUTHOR INFORMATION}

\section{Corresponding Author}

*E-mail: palwinder_singh_2000@yahoo.com (P.S.).

\section{ORCID}

Gurjit Singh: 0000-0002-4648-0578

Palwinder Singh: 0000-0003-2332-5257

Notes

The authors declare no competing financial interest.

\section{ACKNOWLEDGMENTS}

Financial assistance from SERB-DST, New Delhi, and CSIR, New Delhi, is gratefully acknowledged. S.K. thanks CSIR, New Delhi, for SRF, and P.K. thanks SERB-DST for JRF. UGC, New Delhi, is gratefully acknowledged for grant to GNDU under University with Potential for Excellence Programme.

\section{ABBREVIATION}

$\mathrm{IC}_{50}$, concentration for $50 \%$ inhibition; DMSO, dimethyl sulfoxide; ACN, acetonitrile; DMF, dimethylformamide; TFA, trifluoro acetic acid; SEM, standard error mean; i.p., intraperitoneally; MWI, microwave irradiation; QSAR, quantitative structure-activity relationship; CoMFA, comparative molecular field analysis

\section{REFERENCES}

(1) (a) Ward, P. A. Fundamentals of Inflammation; Serhan, C. N., Ward, P. A., Gilroy, D. W., Eds.; Cambridge University Press: Cambridge, 2010; p 1-16. (b) Medzhitov, R. Inflammation 2010: New Adventures of an Old Flame. Cell 2010, 140, 771-776.

(2) (a) Abou-Raya, A.; Abou-Raya, S. Inflammation: A Pivotal Link between Autoimmune Disease and Artherosclerosis. Autoimmun. Rev. 2006, 5, 331-337. (b) Lucas, S.-M.; Rothwell, N. J.; Gibson, R. M. The role of inflammation in CNS Injury and Disease. Br. J. Pharmacol. 2006, 147, S232-S240. (c) Marnett, L. J. Inflammation and Cancer: Chemical Approaches to Mechanisms, Imaging, and Treatment. J. Org. Chem. 2012, 77, 5224-5238. (d) Coussens, L. M.; Werb, Z. Inflammation and Cancer. Nature 2002, 420, 860-867. (e) Ridker, P. M.; Cushman, M.; Stampfer, M. J.; Tracy, R. P.; Hennekens, C. H. Inflammation, Aspirin and The Risk of Cardiovascular disease in Apparently Healthy man. N. Engl. J. Med. 1997, 336, 973-979.

(3) (a) Ballantyne, C. M.; Nambi, V. Markers of Inflammation and their clinical significance. Atherosclerosis Suppl. 2005, 6, 21-29. (b) Ridker, P. M.; Hennekens, C. H.; Buring, J. E.; Rifai, N. CReactive Protein and Other Markers of Inflammation in the prediction of Cardiovascular disease in women. N. Engl. J. Med. 2000, 342, 836843. (c) Stanisic, M.; Lyngstadaas, S. P.; Pripp, A. H.; Aasen, A. O.; Lindegaard, K.-F.; Ivanovic, J.; Ilstad, E.; Konglund, A.; Sandell, T.; Ellingsen, O.; Sæhle, T. Chemokines as markers of local inflammation and angiogenesis in patients with chronic subdural hematoma: a prospective study. Acta Neurochir. 2012, 154, 113-120. (d) Teixeira, B. C.; Lopes, A. L.; Macedo, R. C. O.; Correa, C. S.; Ramis, T. R.; Ribeiro, J. L.; Reischak-Oliveira, A. Inflammatory markers, endothelial function and cardiovascular risk. J. Vasc. Bras. 2014, 13, 108-115. (e) Barnes, P. J.; Karin, M. Nuclear Factor- KB - A Pivotal Transcription Factor in Chronic Inflammatory Diseases. N. Engl. J. Med. 1997, 336, 1066-1071. (f) Lawrence, T. The Nuclear Factor NF-KB Pathway in Inflammation. Cold Spring Harb Perspect Biol. 2009, 1, a001651. (g) Szmitko, P. E.; Wang, C.-H.; Weisel, R. D.; de Almeida, J. R.; Anderson, T. J.; Verma, S. New Markers of Inflammation and Endothelial Cell Activation. Circulation 2003, 108, 1917-1923. (h) Libby, P.; Ridker, P. M. Novel Inflammatory Markers of Coronary Risk. Circulation 1999, 100, 1148-1150. (i) Lubrano, V.; Balzan, S. Consolidated and Emerging Inflammatory Markers in coronary artery disease. World J. Exp. Med. 2015, 5, 21-32. (j) Suzuki, H.; Kayama, Y.; Sakamoto, M.; Iuchi, H.; Shimizu, I.; Yoshino, T.; Katoh, D.; Nagoshi, T.; Tojo, K.; Minamino, T.; Yoshimura, M.; Utsunomiya, K. Arachidonate 12/15- Lipoxygenase-Induced Inflammation and Oxidative Stress Are Involved in the Development of Diabetic Cardiomyopathy. Diabetes 2015, 64, 618-630.

(4) (a) Rocca, B.; FitzGerald, G. A. Cyclooxygenases and Prostaglandins: shaping up the immune response. Int. Immunopharmacol. 2002, 2, 603-630. (b) Needleman, P.; Truk, J.; Jakschik, B. A.; Morrison, A. R; Lefkowith, J. B. Arachidonic acid metabolism. Annu. Rev. Biochem. 1986, 55, 69-102. (c) Smith, W. L.; Garavito, R. M.; DeWitt, D. L. Prostaglandin endoperoxide $\mathrm{H}$ synthases (cyclooxygenases)-1 and -2. J. Biol. Chem. 1996, 52, 33157-33160. 
(d) Dubois, R. N.; Abramson, S. B.; Crofford, L.; Gupta, R. A.; Simon, L. S.; Van De Putte, L. B. A.; Lipsky, P. E. Cyclooxygenase in biology and disease. Faseb. J. 1998, 12, 1063-1073. (e) Marnett, L. J.; Rowlinson, S. W.; Goodwin, D. C.; Kalgutkar, A. S.; Lanzo, C. A. Arachidonic acid oxygenation by COX-1 and COX-2. J. Biol. Chem. 1999, 274, 22903-22906. (f) Garavito, R. M.; DeWitt, D. L. The cyclooxygenase isoforms: structural insights into the conversion of arachidonic acid to prostaglandins. Biochim. Biophys. Acta 1999, 1441, 278-287.

(5) (a) Vane, J. R.; Bakhle, Y. S.; Botting, R. M. Cyclooxygenases 1 and 2. Annu. Rev. Pharmacol. Toxicol. 1998, 38, 97-120. (b) Pairet, M.; Engelhardt, G. Distinct isoforms (COX-1 and COX-2) of cyclooxygenase: possible physiological and therapeutic implications. Fundam. Clin. Pharmacol. 1996, 10, 1-15. (c) Rouzer, C. A.; Marnett, L. J. Cycooxygenases: structural and functional insights. J. Lipid Res. 2009, S29-S34.

(6) (a) Zidar, N.; Odar, K.; Glavac, D.; Jerse, M.; Zupanc, T.; Stajer, D. Cyclooxygenase in normal human tissues- is COX-1 really a constitutive isoform, and COX-2 an inducible form. J. Cell. Mol. Med. 2009, 13, 3753-3763. (b) Simmons, D. L.; Botting, R. M.; Hla, T. Cyclooxygenase Isozymes: The biology of prostaglandin synthesis and inhibition. Pharmacol. Rev. 2004, 56, 387-437. (c) Ricciotti, E.; FitzGerald, G. A. Prostaglandins and inflammation. Arterioscler. Thromb. Vasc. Biol. 2011, 31, 986-1000. (d) Gilroy, D. W.; ColvilleNash, P. R. New insights into role of COX-2 in inflammation. J. Mol. Med. 2000, 78, 121-129. (e) Tilley, S. L.; Coffman, T. M.; Koller, B. $\mathrm{H}$. Mixed messages: modulation of inflammation and immune responses by prostaglandins and thromboxanes. J. Clin. Invest. 2001, 108, 15-23. (f) Patrono, C.; Baigent, C. Low-dose aspirin, coxibs, and other NSAIDS: a clinical mosaic emerges. Mol. Interv. 2009, 9, 31-39. (g) Skoutakis, V. A.; Carter, C. A.; Mickle, T. R.; Smith, V. H.; Arkin, C. R.; Alissandratos, J.; Petty, D. E. Review of diclofenac and evaluation of its place in therapy as a nonsteroidal anti-inflammatory agent. Drug Intell. Clin. Pharm. 1988, 22, 850-859.

(7) (a) Brunton, L.; Chabner, B.; Knollman, B. Anti-Inflammatory, Antipyretic and Analgesic Agents. In The Pharmacological Basis of Therapeutics, 12th ed.; Goodman, L. S., Gilman, A., Eds.; McGraw-Hill Inc: New York, 2011; Chapter 34, pp 959-1003. (b) Shi, S.; Klotz, U. Clinical use and pharmacological properties of selective COX-2 inhibitors. Eur. J. Clin. Pharmacol. 2008, 64, 233-252. (c) Chan, F. K. L.; Hung, L. C. T.; Suen, B. Y.; Wu, J. C. Y.; Lee, K. C.; Leung, V. K. S.; Hui, A. J.; To, K. F.; Leung, W. L.; Wong, V. W. S.; Chung, S. C. S.; Sung, J. J. Y. Celecoxib versus diclofenac and omeprazole in reducing the risk of recurrent ulcer bleeding in patients with arthritis. N. Engl. J. Med. 2002, 347, 2104-2110. (d) Moore, R. A.; Derry, S.; Phillips, C. J.; McQuay, H. J. Nonsteroidal anti-inflammatory drugs (NSAIDs), cyclooxygenase-2 selective inhibitors (coxibs) and gastrointestinal harm: review of clinical trials and clinical practice. BMC Muscoskel. Disord. 2006, 7, 79. (e) Capone, M. L.; Tacconelli, S.; Sciulli, M. G.; Patrignani, P. Clinical pharmacology of selective COX-2 inhibitors. Int. J. Immunopathol. Pharmacol. 2003, 16, 49-58. (f) Dogné, J.-M.; Supuran, C. T.; Pratico, D. Adverse cardiovascular effects of the coxibs. J. Med. Chem. 2005, 48, 2251-2256. (g) Kawahito, Y. Clinical implications of cyclooxygenase-2 inhibitors. Inflamm. Regen. 2007, 27, 552-558.

(8) (a) White, W. B.; West, C. R.; Borer, J. S.; Gorelick, P. B.; Lavange, L.; Pan, S. X.; Weiner, E.; Verburg, K. M. Risk of cardiovascular events in patients receiving celecoxib: A meta-analysis of randomized clinical trials. Am. J. Cardiol. 2007, 99, 91-98. (b) Brueggemann, L. I.; Mackie, A. R.; Mani, B. K.; Cribbs, L. L.; Byron, K. L. Differential effects of selective cyclooxygenase-2 inhibitors on vascular smooth muscle ion channels may account for differences in cardiovascular risk profiles. Mol. Pharmacol. 2009, 76, 1053-1061. (c) FitzGerald, G. A. Cardiovascular pharmacology of nonselective nonsteroidal anti-inflammatory drugs and coxibs: clinical considerations. Am. J. Cardiol. 2002, 89, 26-32. (d) Solomon, S. D.; McMurray, J. J. V.; Pfeffer, M. A.; Wittes, J.; Fowler, R.; Finn, P.; Anderson, W. F.; Hawk, E.; Bertagnolli, M. Cardiovascular risk associated with celecoxib in a clinical trial for colorectal adenoma prevention. N. Engl. J. Med. 2005, 352, 1071-1080. (e) Cairns, J. A. The coxibs and traditional nonsteroidal anti-inflammatory drugs: A current perspective on cardiovascular risks. Can. J. Cardiol. 2007, 23, 125-131.

(9) (a) Li, J. J. Heterocyclic Chemistry in Drug Discovery; John Wiley and Sons Inc: Hoboken, New Jersey, 2013. (b) Biswal, S.; Sahoo, U.; Sethy, S.; Kumar, H. K. S.; Banerjee, M. Indole: The Molecule of Diverse Biological Activities. Asian J. Pharm. Clin. Res. 2012, 5, 1-6. (c) Kumar, J. R. Review of Imidazole Heterocyclic Ring containing Compounds with their Biological Activity. Pharmacophore 2010, 1, 167-177. (d) Dua, R.; Shrivastava, S.; Sonwane, S. K.; Srivastava, S. K. Pharmacological Significance of Synthetic Heterocycles Scaffold: A Review. Adv. Biol. Res. 2011, 5, 120-144.

(10) (a) Abdel-Megeed, A. M.; Abdel-Rahman, H. M.; Alkaramany, G.-E. S.; El-Glendy, M. A. Design, synthesis and molecular modeling study of acylated 1,2,4-triazole-3-acetates with potential antiinflammatory activity. Eur. J. Med. Chem. 2009, 44, 117-123. (b) Banerjee, A. G.; Das, N.; Shengule, S. A.; Srivastava, R. S.; Shrivastava, S. K. Synthesis, characterization, evaluation and molecular dynamics studies of 5, 6-diphenyl-1,2,4-triazine-3- $(2 \mathrm{H})$-one derivatives bearing 5esubstituted 1,3,4-oxadiazole as potential anti-inflammatory and analgesic agents. Eur. J. Med. Chem. 2015, 101, 81-95. (c) Dianzani, C.; Collino, M.; Gallicchio, M.; Fantozzi, R.; Samaritani, S.; Signore, G.; Menicagli, R. Evaluation of in-vitro antiinflammatory activity of some 2-alkyl-4,6-dimethoxy-1,3,5 triazines. J. Pharm. Pharmacol. 2006, 58, 219-226. (d) Shah, D. R.; Modh, R. P.; Chikhalia, K. H. Privileged $s$-triazines: structure and pharmacological applications. Future Med. Chem. 2014, 6, 463-477. (e) Zhou, C.-H.; Wang, Y. Recent Researches in Triazole Compounds as Medicinal Drugs. Curr. Med. Chem. 2012, 19, 239-280. (f) Singla, P.; Luxami, V.; Paul, K. Triazine as a promising scaffold for its versatile biological behavior. Eur. J. Med. Chem. 2015, 102, 39-57.

(11) Triazine based heterocycles: (a) Avupati, V. R.; Yejella, R. P.; Parala, V. R.; Killari, K. N.; Papasani, V. M. R.; Cheepurupalli, P.; Gavalapu, V. R.; Boddeda, B. Synthesis, characterization and in vitro biological evaluation of some novel 1,3,5-triazine-Schiff base conjugates as potential antimycobacterial agents. Bioorg. Med. Chem. Lett. 2013, 13, 5968-5970. (b) Pastorin, G.; Federico, S.; Paoletta, S.; Corradino, M.; Cateni, F.; Cacciari, B.; Klotz, K.-N.; Gao, Z.-G.; Jacobson, K. A.; Spalluto, G.; Moro, S. Synthesis and pharmacological characterization of a new series of 5,7-disubstituted-[1,2,4] triazolo[1,5a] $[1,3,5]$ triazine derivatives as adenosine receptor antagonists: A preliminary inspection of ligand-receptor recognition process. Bioorg. Med. Chem. 2010, 18, 2524-2536. (c) Wani, M. Y.; Bhat, A. R.; Azam, A.; Choi, I.; Athar, F. Probing the antiamoebic and cytotoxicity potency of novel tetrazole and triazine Derivatives. Eur. J. Med. Chem. 2012, 48, 313-320. (d) Popowycz, F.; Schneider, C.; DeBonis, S.; Skoufias, D. A.; Kozielski, F.; Galmarini, C. M.; Joseph, B. Synthesis and antiproliferative evaluation of pyrazolo[1,5-a]-1,3,5-triazine myoseverin derivatives. Bioorg. Med. Chem. 2009, 17, 3471-3478. (e) Sunduru, N.; Agarwal, A.; Katiyar, S. B.; Nishi; Goyal, N.; Gupta, S.; Chauhan, P. M. S. Synthesis of 2,4,6-trisubstituted pyrimidine and triazine heterocycles as antileishmanial agents. Bioorg. Med. Chem. 2006, 14, 7706-7715. (f) Vilaivan, T.; Saesaengseerung, N.; Jarprung, D.; Kamchonwongpaisan, S.; Sirawaraporn, W.; Yuthavong, Y. Synthesis of Solution-Phase Combinatorial Library of 4,6-Diamino1,2-dihydro-1,3,5-triazine and Identification of New Leads Against A16V+S108T Mutant Dihydrofolate Reductase of Plasmodium falciparum. Bioorg. Med. Chem. 2003, 11, 217-224. (g) Zhou, C.; Min, J.; Liu, Z.; Young, A.; Deshazer, H.; Gao, T.; Chang, Y.-T.; Kallenbach, N. R. Synthesis and biological evaluation of novel 1,3,5triazine derivatives as antimicrobial agents. Bioorg. Med. Chem. Lett. 2008, 18, 1308-1311. (h) Krečmerová, M.; Masojídková, M.; Holý, A. Acyclic nucleoside phosphonates with 5-azacytosine base moiety substituted in C-6 position. Bioorg. Med. Chem. 2010, 18, 387-395. (i) Sunduru, N.; Gupta, L.; Chaturvedi, V.; Dwivedi, R.; Sinha, S.; Chauhan, P. M. S. Discovery of new 1, 3, 5-triazine scaffolds with potent activity against Mycobacterium tuberculosis H37Rv. Eur. J. Med. Chem. 2010, 45, 3335-3345. (j) Garaj, V.; Puccetti, L.; Fasolis, 
G.; Winum, J.-Y.; Montero, J.-L.; Scozzafava, A.; Vullo, D.; Innocenti, A.; Supuran, C. T. Carbonic anhydrase inhibitors: Novel sulfonamides incorporating 1,3,5-triazine moieties as inhibitors of the cytosolic and tumour-associated carbonic anhydrase isozymes I, II and IX. Bioorg. Med. Chem. Lett. 2005, 15, 3102-3108. (k) Sosič, I.; Mirković, B.; Turk, S.; Štefane, B.; Kos, J.; Gobec, S. Discovery and kinetic evaluation of 6-substituted 4-benzylthio-1,3,5-triazin-2(1H)-ones as inhibitors of cathepsin B. Eur. J. Med. Chem. 2011, 46, 4648-4656.

(12) Indole based heterocycles: (a) Sharma, V.; Kumar, P.; Pathak, D. Biological Importance of the Indole Nucleus in Recent Years: A Comprehensive Review. J. Heterocycl. Chem. 2010, 47, 491-502. (b) Kaushik, N.; Kaushik, N.; Attri, P.; Kumar, N.; Kim, C. H.; Verma, A.; Choi, E. Biomedical Importance of Indoles. Molecules 2013, 18, 6620-6662.

(13) Pyrazole based heterocycles: (a) Chauhan, A.; Sharma, P. K.; Kaushik, N. Pyrazole: A Versatile Moiety. Int. J. Tech. Res. 2011, 3, 1117. (b) Shaveta; Singh, A.; Kaur, M.; Sharma, S.; Bhatti, R.; Singh, P. Rational design, synthesis and evaluation of chromone-indole and chromone-pyrazole based conjugates: Identification of a lead for antiinflammatory drug. Eur. J. Med. Chem. 2014, 77, 185-192. (c) Küçükgüzel, Ş. G.; Senkardes, S. Recent advances in bioactive pyrazoles. Eur. J. Med. Chem. 2015, 97, 786-815.

(14) (a) Khanum, S. A.; Begum, B. A.; Girish, V.; Khanum, N. F. Synthesis and Evaluation of Benzophenone-N-ethyl Morpholine Ethers as Anti-inflammatory Agents. Int. J. Biomed. Sci. 2010, 6, 6065. (b) Murhekar, M. M.; Padghan, P. D.; Mhaske, S. S.; Khadsan, R. E. Synthesis and Antimicrobial activity of new series of s-triazines and its derivatives Synthesis and Antimicrobial activity of new series of striazines and its derivatives. Der Pharma Chem. 2011, 3, 243-246. (c) Panneerselvam, P.; Priya, M.; Kumar, N.; Saravanan, G. Synthesis and Pharmacological Evaluation of Schiff Bases of 4-(2-Aminophenyl)Morpholines. Ind. J. Pharm. Sci. 2009, 71, 428-432.

(15) (a) Singh, P.; Shaveta; Sharma, S.; Bhatti, R. Rationally Designed Hybrid Molecules with Appreciable COX-2 Inhibitory and Antinociceptive Activities. Bioorg. Med. Chem. Lett. 2014, 24, 77-82. (b) Singh, P.; Kaur, J.; Singh, G.; Bhatti, R. Tri-block Conjugates: Identification of a Highly Potent Anti-inflammatory Agent. J. Med. Chem. 2015, 58, 5989-6001.

(16) COX Inhibitor Screening Assay Kit, Item No. 560131. Cayman Chemical Co.

(17) (a) Baell, J. B.; Ferrins, L.; Falk, H.; Nikolakopoulos, G. PAINS: Relevance to Tool Compound Discovery and Fragment-Based Screening. Aust. J. Chem. 2013, 66, 1483-1494. (b) Baell, J. B.; Holloway, G. A. New Substructure Filters for Removal of Pan Assay Interference compounds (PAINS) from Screening Libraries and for Their Exclusion in Bioassays. J. Med. Chem. 2010, 53, 2719-2740. (c) Doman, T. N.; McGovern, S. L.; Witherbee, B. J.; Kasten, T. P.; Kurumbail, R.; Stallings, W. C.; Connolly, D. T.; Shoichet, B. K. Molecular Docking and High-Throughput Screening for Novel Inhibitors of Protein Tyrosine Phosphatase- $\mathrm{I}<\mathrm{SUB}>\mathrm{B}</ \mathrm{SUB}\rangle$. J. Med. Chem. 2002, 45, 2213-2221. (d) Rajamaki, S.; Innitzer, A.; Falciani, C.; Tintori, C.; Christ, F.; Witvrouw, M.; Debyser, Z.; Massa, S.; Botta, M. Exploration of Novel Thiobarbituric acid, Rhodamineand Thiohydantoin-Based HIV-1 Integrase Inhibitors. Bioorg. Med. Chem. Lett. 2009, 19, 3615-3618. (e) Baell, J.; Walters, M. A. Chemical Con Artists Foil Drug Discovery. Nature 2014, 513, 481483.

(18) (a) Warner, T. D.; Giuliano, F.; Vojnovic, I.; Bukasa, A.; Mitchell, J. A.; Vane, J. R. Nonsteroid drug selectivities for cyclooxygenase-1 rather than cyclo-oxygenase- 2 are associated with human gastrointestinal toxicity: A full in vitro analysis. Proc. Natl. Acad. Sci. U.S.A. 1999, 96, 7563-7568. (b) Laufer, S.; Greim, C.; Luik, S.; Ayoub, S. S.; Dehner, F. Human whole blood assay for rapid and routine testing of non-steroidal anti-inflammatory drugs (NSAIDs) on cyclo-oxygenase-2 activity. Inflammopharmacology 2008, 16, 155-161.

(19) TXB2 Express ELISA kit-Monoclonal, Item No. 10004023. Cayman Chemical Co.

(20) Singh, P.; Kaur, S.; Kaur, J.; Singh, G.; Bhatti, R. Rational Design of Small Peptides for Optimal Inhibition of Cyclooxygenase-2:
Development of a Highly Effective Anti-inflammatory Agent. J. Med. Chem. 2016, 59, 3920-3934.

(21) Acute Oral Toxicity-Acute Toxic Class Method. OECD Guidelines for Testing of Chemicals; Guideline 423; OECD: Paris, 2001.

(22) Kiefer, J. R.; Pawlitz, J. L.; Moreland, K. L.; Stegeman, R. A.; Hood, W. F.; Gierse, J. K.; Stevens, A. M.; Goodwin, D. C.; Rowlinson, S. W.; Marnett, L. J.; Stallings, W. C.; Kurumbail, R. G. Structural insights into the stereochemistry of the cyclooxygenase reaction. Nature 2000, 405, 97-101.

(23) Malkowski, M. G.; Ginell, S. L.; Smith, W. L.; Garavito, R. M. The productive conformation of arachidonic acid bound to prostaglandin synthase. Science 2000, 289, 1933-1937.

(24) (a) Greenwood, J. R.; Calkins, D.; Sullivan, A. P.; Shelley, J. C. Towards the comprehensive, rapid, and accurate prediction of the favorable tautomeric states of drug-like molecules in aqueous solution. J. Comput. Aided Mol. Des. 2010, 24, 591-604. (b) Shelley, J. C.; Cholleti, A.; Frye, L. L.; Greenwood, J. R.; Timlin, M. R.; Uchimaya, M. Epik: a software program for $p K_{\mathrm{a}}$ prediction and protonation state generation for drug-like molecules. J. Comput.-Aided Mol. Des. 2007, 21, 681-691. (c) Shivakumar, D.; Williams, J.; Wu, Y.; Damm, W.; Shelley, J.; Sherman, W. Prediction of absolute solvation free energies using molecular dynamics free energy perturbation and the OPLS force field. J. Chem. Theory Comput. 2010, 6, 1509-1519. (d) Jorgensen, W. L.; Maxwell, D. S.; Tirado-Rives, J. Development and testing of the OPLS all-atom force field on conformational energetics and properties of organic liquids. J. Am. Chem. Soc. 1996, 118, 11225-11236. (e) Jorgensen, W. L.; Tirado-Rives, J. The OPLS [optimized potentials for liquid simulations] potential functions for proteins, energy minimizations for crystals of cyclic peptides and crambin. J. Am. Chem. Soc. 1988, 110, 1657-1666.

(25) Pauli, G. F.; Chen, S.-N.; Simmler, C.; Lankin, D. C.; Gödecke, T.; Jaki, B. U.; Friesen, J. B.; McAlpine, J. B.; Napolitano, J. G. Importance of purity evaluation and the potential of quantitative ${ }^{1} \mathrm{H}$ NMR as a purity assay. J. Med. Chem. 2014, 57, 9220-9231.

(26) Zhang, Y.; Huo, M.; Zhou, J.; Xie, S. PKSolver: An add-in program for pharmacokinetic and pharmacodynamic data analysis in Microsoft Excel. Comput. Meth. Progr. Biomed. 2010, 99, 306-314. 